
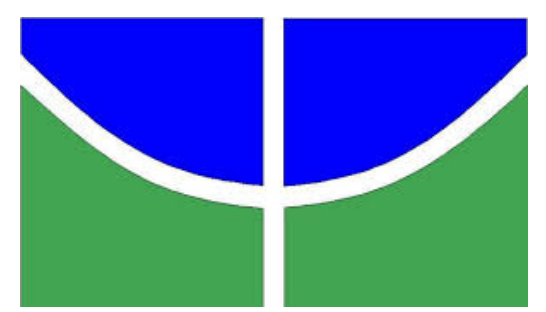

UNIVERSIDADE DE BRASÍLIA FACULDADE DE DIREITO

ANDRÉA DE FREITAS VARELA

MOBILIDADE URBANA, TRANSPORTE E DIREITO CONSTITUCIONAL NO BRASIL: UMA ABORDAGEM CRÍTICA 


\section{MOBILIDADE URBANA, TRANSPORTE E DIREITO CONSTITUCIONAL NO BRASIL: UMA ABORDAGEM CRÍTICA}

Dissertação apresentada ao Curso de PósGraduação em Direito da Universidade de Brasília como requisito parcial para a obtenção do grau de Mestre em Direito. Área de Concentração: Direito, Estado e Constituição. Linha de Pesquisa: Transformações da ordem social, econômica e regulação.

\section{Orientador}

Prof. Dr. Marcus Faro de Castro 


\section{MOBILIDADE URBANA, TRANSPORTE E DIREITO CONSTITUCIONAL NO BRASIL: UMA ABORDAGEM CRÍTICA}

Dissertação apresentada ao Curso de PósGraduação em Direito da Universidade de Brasília como requisito parcial para a obtenção do grau de Mestre em Direito. Área de Concentração: Direito, Estado e Constituição. Linha de Pesquisa: Transformações da ordem social, econômica e regulação.

Aprovada em 28 de outubro de 2015.

\section{BANCA EXAMINADORA:}

Prof. Dr. Marcus Faro de Castro (Orientador)

Universidade de Brasília - UnB

Prof. Dr. Márcio Nunes Iório Aranha Oliveira

Universidade de Brasília - UnB

Prof. Dr. Marcos Galileu Lorena Dutra

Fundação Getúlio Vargas - FGV 
Ao Senhor dos senhores e à Mulher Vestida de Sol (Ap.12) que sempre iluminam o meu caminho. 


\section{AGRADECIMENTOS}

À Mulher Vestida de Sol (Ap. 12) que sempre iluminou meu caminho e a minha mãe, Marlene de Freitas Varela, que sempre esteve comigo durante a jornada.

Ao meu orientador, Prof. Dr. Marcus Faro de Castro, pela confiança e paciência e por compartilhar comigo o seu vasto conhecimento.

Aos colegas do Grupo de Pesquisa Direito, Economia e Sociedade, Paulo Sampaio, Hugo Pena e Euler Lopes, pelos conselhos sempre valiosos e pelo constante incentivo. 


\section{RESUMO}

A dissertação estuda aspectos jurídicos relativos às dimensões econômicas das políticas brasileiras de mobilidade urbana. Em especial, o trabalho explora a insuficiência do discurso do direito constitucional no Brasil para enfrentar as questões que contenham uma dimensão econômica importante e explora vias analíticas alternativas. $\mathrm{O}$ trabalho ressalta a importância de se considerar a mobilidade urbana como problema não apenas econômico, mas também, e sobretudo, jurídico, não obstante as limitações do discurso do direito constitucional. Inicialmente, é apresentado um breve histórico acerca da legislação dos meios de transporte implementados no Brasil desde a época do Império até os dias atuais, sublinhando-se os aspectos econômicos e políticos que permearam as escolhas dos legisladores. Em seguida, é realizada uma apreciação crítica das abordagens tanto do direito constitucional calcado na dogmática jurídica quanto no neoconstitucionalismo a respeito do direito constitucional de ir e vir, sendo destacados aspectos problemáticos de ambas as perspectivas. O trabalho explora, ainda, duas outras abordagens jurídicas que focalizam com maior acuidade aspectos econômicos de políticas públicas: a da Análise Econômica do Direito (AED) e a da Análise Jurídica da Política Econômica (AJPE). O trabalho apresenta críticas à abordagem defendida pela AED e se utiliza da metodologia da AJPE como instrumento de abordagem da fruição do direito fundamental de ir e vir em meios urbanos circunscritos empiricamente. Por fim, apresenta as sugestões para melhoria da política analisada e expõe a conclusão final obtida após a realização da pesquisa.

Palavras-Chaves: direito de ir e vir, mobilidade urbana, transportes, discurso jurídico, política, economia, dogmática jurídica, neoconstitucionalismo, Análise Econômica do Direito, Análise Jurídica da Política Econômica. 


\begin{abstract}
This dissertation studies legal aspects related to the economic dimensions of urban mobility policies in Brazil. In particular, the work indicates the gap of the Brazilian constitutional discourse related to the economic dimension and presents an alternative to that discourse. The work highlights the importance of considering urban mobility not only as an economic problem, but also, and above all, as a legal problem, despite the limitations of the Brazilian constitutional discourse. Initially, it presents a brief history of the transport legislation implemented in Brazil since the Empire period until the present days, underlining the economic and political aspects that permeated the legislators' choices. It also presents a critical assessment of approaches stepped on legal dogmatism and on neoconstitucionalismo. The work explores two other legal approaches that focus more accurately on economic aspects of public policies: the Law and Economics and the Legal Analysis of Economic Policy (LAEP). It criticizes the approach advocated by Law and Economics and use the LAEP methodology as an instrument to demonstrate the fruition of right, in this case, freedom of movement in two different areas of the Distrito Federal. At last, it presents suggestions for improving the urban mobility policy and exposes the final conclusion obtained through the research.
\end{abstract}

Key words: freedom of movement, urban mobility, transports, legal discourse, politics, economics, legal dogmatic, Neoconstitutionalismo, Law and Economics, Legal Analysis of Economic Policy (LAEP). 


\section{LISTA DE TABELAS}

Tabela $\mathrm{n}^{\circ} 1$ - Taxa de urbanização

Tabela $n^{\circ} 2$ - Classes de renda - distribuição de domicílios ocupados segundo as classes de renda domiciliar em Águas Claras

Tabela $\mathrm{n}^{\circ} 3$ - Classes de renda - distribuição de domicílios ocupados segundo as classes de renda domiciliar em Vicente Pires

Tabela $n^{\circ} 4$ - Acidentes de trânsito com morte - por via - RA Águas Claras

Tabela $n^{\circ} 5$ - Acidentes de trânsito com morte - por via - RA Vicente Pires

Tabela $n^{\circ} 6$ - Número de acidentes com morte e número de habitantes

Tabela n 7 - Extensão das Ciclovias no Distrito Federal

Tabela $n^{\circ} 8$ - Território e extensão da malha cicloviária

Tabela nº 9 - Salário mínimo e valor da passagem

Tabela $\mathrm{n}^{\mathrm{o}} 10$ - Modal mais utilizado

Tabela n ${ }^{o} 11$ - Pesquisa de satisfação

Tabela ${ }^{\circ} 12$ - Número de habitantes e número de deslocamentos por motivos profissionais 


\section{LISTA DE GRÁFICOS}

Gráfico ${ }^{\circ} 1$ - Distribuições de viagens urbanas na cidade do Rio de Janeiro (1950-2005)

Gráfico n ${ }^{\circ} 2$ - Investimento Público em Infraestrutura de Transporte - Valor Total e Recursos da CIDE

\section{LISTA DE FÓRMULAS}

Fórmula no 1 - Índice de Fruição Empírica (IFE)

Fórmula nº 1.1 - IFE quantificado de Águas Claras

Fórmula n ${ }^{\mathrm{o}} 1.2$ - IFE quantificado de Vicente Pires

Fórmula nº 2 - Padrão de Validação Jurídica 


\section{LISTA DE SIGLAS E ABREVIATURAS}

ADI

AED

AJPE

ANTAQ

ANTF

ANTP

ANTT

BNDE

BNDES

BNH

CEF

CEPAL

CIDE

CMBEU

CODEPLAN

CONAMA

CONTRAN

CRFB

DENATRAN

DETRAN

DF TRANS

DNER

DNIT

EBTU

EC
Ação Direta de Inconstitucionalidade

Análise Econômica do Direito

Análise Jurídica da Política Econômica

Agência Nacional de Transportes Aquaviários

Associação Nacional dos Transportadores Ferroviários

Associação Nacional do Transporte Público

Agência Nacional de Transportes Terrestres

Banco Nacional do Desenvolvimento Econômico

Banco Nacional do Desenvolvimento Econômico e Social

Banco Nacional de Habitação

Caixa Econômica Federal

Comissão Econômica para América Latina e Caribe

Contribuição sobre Intervenção do Domínio Econômico

Comissão Mista Brasil-Estados Unidos

Companhia de Planejamento do Distrito Federal

Conselho Nacional do Meio Ambiente

Conselho Nacional de Trânsito

Constituição da República Federativa do Brasil

Departamento Nacional de Trânsito

Departamento Estadual de Trânsito

Transporte Urbano do Distrito Federal

Departamento Nacional de Estradas e Rodagem

Departamento Nacional de Infraestrutura de Transportes

Empresa Brasileira de Transporte Urbano

Emenda Constitucional 
HC

IFE

IPEA

NTU

OCDE

ONU

PDAD

PGT

PIB

PlanMob

PNMU

PNV

PVJ

RA

RE

SeMOB

SNAPU

SNH

SNSA

SLS

STA
Estudo de Impacto Ambiental

Estudo de Impacto de Vizinhança

Estados Unidos da América

Fundo de Desenvolvimento dos Transportes Urbanos

Fundo de Financiamento de Estudos e Projetos

Fundo Nacional de Desenvolvimento Urbano

Habeas Corpus

Índice de Fruição Empírica

Instituto de Pesquisa Econômica Aplicada

Associação Nacional das Empresas de Transporte Urbano

Organização para Cooperação e Desenvolvimento Econômico

Organização das Nações Unidas

Pesquisa Distrital de Amostra Domiciliar

Polo Gerador de Tráfego

Produto Interno Bruto

Plano Diretor de Transporte e da Mobilidade Urbana

Política Nacional de Mobilidade Urbana

Plano Nacional de Viação

Padrão de Validação Jurídica

Região Administrativa

Recurso Extraordinário

Secretaria Nacional de Transporte e da Mobilidade Urbana

Secretaria Nacional de Acessibilidade e Programas Urbanos

Secretaria Nacional de Habitação

Secretaria Nacional de Saneamento Ambiental

Suspensão Liminar de Sentença

Suspensão de Tutela Antecipada 
Superior Tribunal de Justiça

Tribunal de Contas da União 


\section{SUMÁRIO}

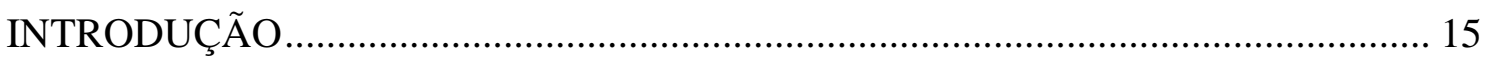

1. HISTÓRICO DA LEGISLAÇÃO DOS TRANSPORTES E DA MOBILIDADE

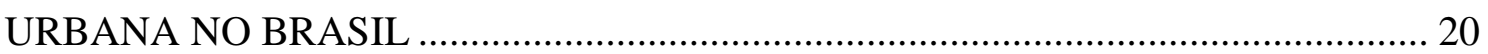

1.1. Do Período Imperial até o Início da Era Vargas ................................................. 20

1.1.1. Observações iniciais ............................................................................ 20

1.1.2. O ferroviarismo e o Brasil rural .............................................................. 20

1.1.3. Os bondes elétricos e o início da expansão urbana........................................ 29

1.2. Da Era Vargas até o início da Nova República: a ascensão do rodoviarismo e a urbanização do Brasil............................................................................ 36

1.3. Da mobilidade urbana - mudança de paradigma................................................ 47

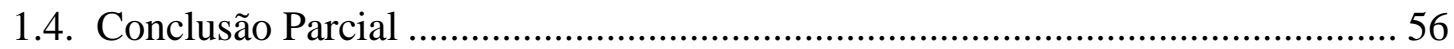

2. AS LIMITAÇÕES DO DISCURSO JURIDICO PREDOMINANTE NO BRASIL ACERCA DOS ASPECTOS POLÍTICO-ECONÔMICOS DA GRATUIDADE DO

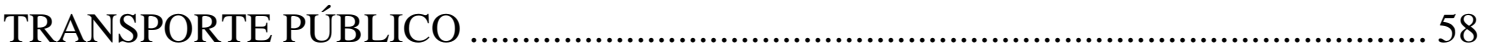

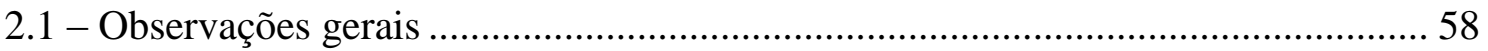

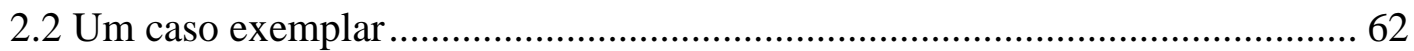

2.3 Superficialidade no tratamento da dimensão econômica ...................................... 69

3. A MOBILIDADE URBANA COMO PROBLEMA JURÍDICO-ECONÔMICO.... 78

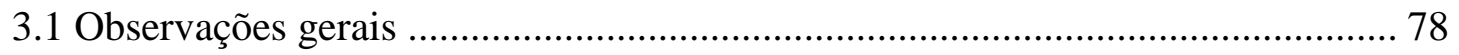

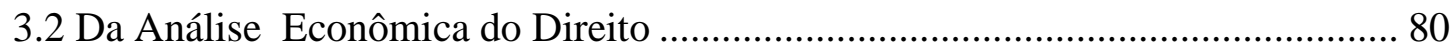

3.3 Da Análise Jurídica da Política Econômica .......................................................... 85

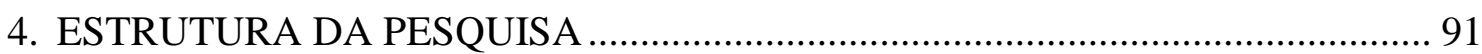

4.1. Delimitação do contexto empírico: a escolha das regiões administrativas.......... 91

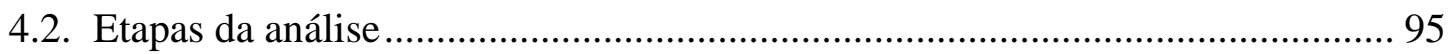

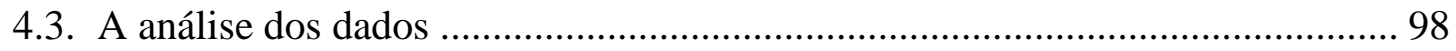

A) Identificação da Política Pública ……………………………………….... 98

B) Identificação do Direito Fundamental correlato:.............................................. 98

C) Decomposição analítica do direito................................................................ 98

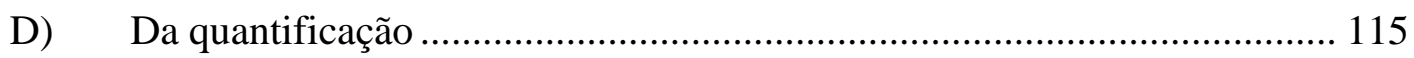

E) Formulação do Índice de Fruição Empírica (IFE)....................................... 117

F) Padrão de Validação Jurídica (PVJ) ....................................................... 118 
5. REVISITANDO A POLÍTICA DE MOBILIDADE ............................................... 120

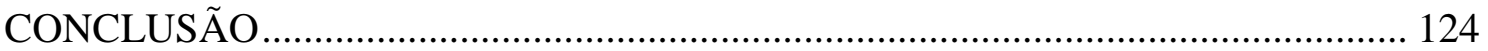

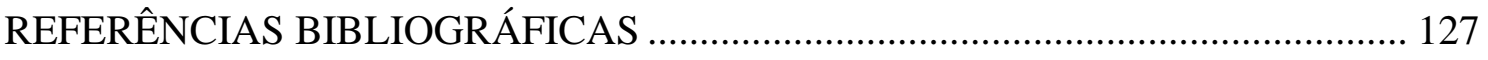




\section{INTRODUÇÃO}

Em junho de 2013, o Brasil foi surpreendido por manifestações que se espalharam por inúmeras cidades do país contra o aumento das tarifas do transporte público urbano. $\mathrm{O}$ mote "Não é apenas 0,20 centavos", que tomava conta das ruas, refletia a indignação da população contra o aumento de tarifas de serviços cuja qualidade da prestação nem sempre justificava o aumento. ${ }^{1}$

As manifestações deram origem a inúmeras ações judiciais que pleiteavam o cancelamento dos reajustes tarifários autorizados pelo poder concedente. Alguns prefeitos, pressionados pelas manifestações, desistiram da interposição de recursos contra as liminares judiciais que vedavam os reajustes e cancelaram os aumentos, ainda que momentaneamente ${ }^{2}$. O Superior Tribunal de Justiça (STJ), após analisar a Suspensão de Liminar e de Sentença (SLS) $\mathrm{n}^{\mathrm{o}}$ 1.490, interposta pelo Município de Palmas, deferiu o pedido do requerente e autorizou o reajuste. Tendo em vista que o prazo para recurso transcorreu in albis, a matéria não chegou a ser analisada pelo Supremo Tribunal Federal. ${ }^{3}$

\footnotetext{
${ }^{1}$ A respeito dos movimentos destaca-se a seguinte matéria "[n]o dia 17 de junho de 2013, a página 3 do GLOBO registrava 'Mais um dia de protestos' A manchete se referia ao crescimento dos protestos em todo o país. Em São Paulo, seria a quinta jornada de manifestações contra o aumento das passagens, promovida pelo Movimento Passe Livre. No texto, os organizadores diziam esperar 20 mil pessoas, embora, nas redes sociais, 190 mil tivessem confirmado presença. [...].

No Rio, a primeira grande manifestação, ainda no dia 17, foi noticiada no dia 18 com o título 'Primavera carioca leva multidão de manifestantes ao Centro'. Mas já ao fim da passeata, da Candelária à Cinelândia, um grupo tentou invadir a Assembleia Legislativa, tocou fogo num carro e depredou lojas, no que teria sido a primeira ação dos black blocs na cidade.

Em São Paulo, 65 mil pessoas foram às ruas. No fim da manifestação, um grupo tentou invadir a sede do governo, o Palácio Bandeirantes, e foi rechaçado pela Polícia Militar com balas de borracha e bombas de efeito moral. Em Brasília, os ativistas ocuparam o teto do Congresso. Houve confrontos isolados entre manifestantes e policiais." (Publicado: 18/12/13 - 11h 30min Atualizado: 18/12/13 - 12h 21min) Disponível em <http://acervo.oglobo.globo.com/em-destaque/junho-de-2013-protestos-contra-aumento-dapassagens-se-espalham-pelo-pais-11101311> Acesso em 04 de fev. de 2015.

${ }^{2}$ Um dos grupos que se insurgiu contra o aumento das passagens foi o Movimento Coletivo, conforme matéria jornalística colacionada adiante: "Coletivo entra na Justiça contra aumento de passagens de ônibus em BH. O reajuste das passagens causou uma revolta da população em 2013. Em junho do ano passado, as manifestações tomaram conta do país, com protestos em quase todas as capitais e em cidades do interior. Na capital mineira, o reajuste de $8 \%$ no valor da tarifa, em vigor desde janeiro, motivou os manifestantes. Pressionado, o prefeito Marcio Lacerda reduziu o valor da tarifa em $\mathrm{R} \$ 0,15$, com a passagem das linhas diametrais caindo de $\mathrm{R} \$ 2,80$ para $\mathrm{R} \$ 2,65$, preço vigente em dezembro de 2012. Em abril desse ano, a PBH descongelou o preço das tarifas, que passou de $\mathrm{R} \$ 2,65$ para $\mathrm{R} \$ 2,85$.” (postado em 28/12/2014 15:39 / atualizado em 28/12/2014 15:59) Disponível em <http://www.em.com.br/app/noticia/gerais/2014/12/28/interna gerais,603081/coletivo-entra-najustica-contra-aumento-de-passagens-de-onibus-em-bh.shtml > Acesso em 08de fev. de 2015

${ }^{3}$ O Município de Palmas recorreu ao Superior Tribunal de Justiça contra a decisão que suspendera o reajuste proferida pelo Tribunal de Justiça do Estado de Tocantins. Em decisão monocrática, o Ministro Presidente Ari Parglender, ao analisar a Suspensão de Liminar e de Sentença (SLS) n ${ }^{\circ}$ 1.490/2013, deferiu o pedido do
} 
A prestação do serviço de transporte público e o respectivo reajuste no valor das tarifas, bem como o aumento dos congestionamentos nas cidades, a ausência de espaços para veículos não motorizados e mesmo para pedestres são reflexos das políticas de mobilidade urbana ou da ausência delas. A discussão acerca da mobilidade nas cidades constitui parte de um debate mais amplo a respeito da Reforma Urbana fortalecido após a promulgação da Constituição Federal de 1988 e impulsionado pela recente edição da Lei no 12.587/12 que instituiu as diretrizes da Política Nacional de Mobilidade Urbana, cujo foco encontra-se não mais na política de transporte, mas na fruição do direito fundamental de ir e vir.

No Brasil, a jurisprudência que discute o direito de ir e vir de um ponto de vista mais ligado aos aspectos de organização da atividade ou de suas dimensões civis é escassa, sendo mais significativa a jurisprudência constitucional de caráter penal. Entre os primeiros casos que remontam o início da República se destacam o $\mathrm{HC} \mathrm{n}^{\circ} 300$, impetrado por Rui Barbosa em favor do Senador Almirante Eduardo Wandernkolk e outros militares que participaram da Revolta da Armada em 1892 contra o governo do Presidente Marechal Floriano (1891-1894). Neste caso, o STF indeferiu o HC sob o argumento de que a ordem para as prisões, ocorridas durante o Estado de Sítio, estava inserida entre as atribuições constitucionais do presidente da República ${ }^{4}$. Ou ainda a ordem concedida no Recurso em Habeas Corpus (RHC) no 2244 , interposto em favor de Manoel Fortunato Araújo da Costa para impedir a entrada de inspetor sanitário no domicílio do paciente sem o seu consentimento. O writ foi julgado em 1905, pouco após a eclosão da Revolta da Vacina, ocorrida no Rio de Janeiro em $1904 .^{5}$

Se por um lado a jurisprudência do STF é farta a respeito dos aspectos criminais relativos ao direito de ir e vir, poucos foram os casos nos quais o egrégio tribunal foi

requerente. De acordo com Parglender, a decisão sobre a regularidade do aumento das passagens não poderia ser deferida no âmbito da antecipação de tutela, sendo necessária a cognição exauriente da matéria de modo a certificar se o aumento fora suficiente para garantir o equilíbrio econômico-financeiro dos contratos. Disponível em

$<$ https://ww2.stj.jus.br/processo/revista/documento/mediado/?componente=MON\&sequencial=20284911\&num registro $=201103038228 \&$ data=20120214\&formato=PDF> Acesso em 10 de jan.2015.

${ }^{4}$ Disponível em

$<$ http://www.stf.jus.br/portal/cms/verTexto.asp?servico=sobreStfConhecaStfJulgamentoHistorico\&pagina=STF DescricaoHC300> Acesso em 10 de jan. de 2015.

${ }^{55}$ Disponível em <

http://www.stf.jus.br/portal/cms/verTexto.asp?servico=sobreStfConhecaStfJulgamentoHistorico\&pagina=STFde scricaoHC2244> Acesso em 10 de jan. de 2015. 
convocado a discutir aspectos de uma "política pública"6 voltada para a fruição do direito de ir e vir. Afinal, hodiernamente, em um número crescente de situações, são as políticas públicas, que organizam os meios práticos propiciadores da fruição de direitos subjetivos pelos seus titulares.

Dentre os casos em que o STF tratou de aspectos da política de transporte urbano, destacam-se: (i) a decisão proferida logo após a edição da Constituição Federal de 1988 a respeito da obrigatoriedade de licitação para concessão de transporte público urbano (STF 89 AG); (ii) a ADI n 2733-6, que julgou inconstitucional lei estadual de iniciativa do Poder Legislativo que concedeu desconto de $50 \%$ na passagem de estudantes, (iii) a decisão proferida na Ação Direta de Inconstitucionalidade (ADI) no 3.768-4 cujo objeto era a discussão sobre a constitucionalidade de lei que definiu percentual para a gratuidade do transporte público urbano para idosos, sem a correspondente fonte de custeio e (iv) uma quarta, similar a anterior, referente à Suspensão de Segurança $\mathrm{n}^{\circ} 3.052$ interposta pela Agência Nacional dos Transportes Terrestre (ANTT) contra decisão que suspendia o percentual de vagas gratuitas para idosos em transporte interestadual de passageiros. ${ }^{7}$

O direito, apesar da "complexidade semântica" do termo, deveria ser visto como "objetivo" e também como "ferramenta" de modulação das decisões voltadas à implementação das politicas públicas. O direito como objetivo atuaria como "bússola" das decisões, afastando o simples caráter intencional dos programas; como ferramenta, o direito possibilitaria a escolha do "tipo de norma" que melhor atendesse à finalidade de determinada política pública. (COUTINHO, 2014, p. 61).

Embora a análise dos aspectos econômicos e políticos representem uma valiosa contribuição para o exercício do direito, aqui entendido como objetivo e como ferramenta, a práxis demonstra que o discurso do direito constitucional brasileiro, influenciado pela abordagem dogmática, de origem sobretudo alemã, e pelo neoconstitucionalismo, de caráter

\footnotetext{
${ }^{6}$ Política pública aqui entendida como sendo os "programas de ação governamental visando coordenar os meios à disposição do Estado e as atividades privadas, para a realização de objetivos socialmente relevantes e politicamente determinados." (BUCCI, 2006, p.241)

${ }^{7}$ No julgamento do Recurso Extraordinário no 22.817, o STF reconheceu a legitimidade do Ministério Público em ajuizar medida judicial questionando o reajuste de tarifa de transporte público. Este caso não foi incluído pois entendeu-se que a despeito da finalidade de garantir o exercício do direito fundamental, o pedido principal foi o reconhecimento da legitimidade do Ministério Público, Neste sentido destaca-se o voto do Ministro Cezar Peluso: "Quem defende, coletivamente, esses interesses? Esse é o problema. Temos aqui uma coletividade que pode estar sendo vítima de fixação abusiva, sem um recurso de caráter coletivo que solucione a matéria. Ou seja, transfiro a discussão do campo dos remédios jurídicos postos à disposição do cidadão." Disponível em http://redir.stf.jus.br/paginadorpub/paginador.jsp?docTP=AC\&docID=609033 >Acesso em 10 de jan. de 2015.
} 
eclético, revela pouco apreço pela análise dos aspectos políticos e econômicos envolvidos na fruição dos direitos fundamentais.

Este pouco apreço, segundo CASTRO (2012, p.9), tem sua origem no apego do direito brasileiro em geral a categorias incapazes de compreender os impactos na vida social provocados pelas políticas públicas e suas consequências para a fruição de direitos, o que atrai a necessidade de uma discussão jurídica, inclusive constitucional, a respeito da fruição do próprio direito fundamental, no caso, o direito de ir e vir. Tal discussão é o que se propõe desenvolver na presente dissertação.

No primeiro capítulo, visando delinear as principais características das políticas de transporte no Brasil e sua evolução, discute-se a legislação dos transportes desde o Império até os dias atuais. Conforme será visto, o foco dessa legislação, incialmente, recaía sobre a preocupação em criar uma infraestrutura útil para fins de exportação dos produtos agrícolas, especialmente o café. Em um segundo momento, serviu como instrumento do processo de industrialização do país. E, em um terceiro momento, que representa uma verdadeira mudança de paradigma, o foco das políticas públicas relevantes transfere-se do transporte para o conceito de "mobilidade urbana".

O segundo capítulo apresentará a análise da decisão proferida no julgamento da ADI

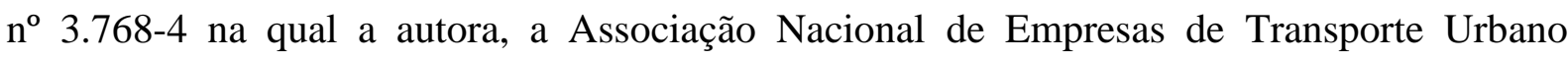
(NTU), questionava a constitucionalidade do art. 39 do Estatuto do Idoso que concedia a gratuidade do transporte público urbano a pessoas com mais de sessenta e cinco anos sem a correspondente fonte de custeio; o que, segundo a NTU, contrariava o precedente do STF proferido no julgamento da $\mathrm{ADI} \mathrm{n}^{\circ}$ 2733, cujos fundamentos também serão analisados brevemente no referido capítulo. A análise do julgamento da ADI no 3.768-4 visa demonstrar o pouco apreço do discurso jurídico tradicional (considerando os referenciais analíticos da dogmática jurídica e do neoconstitucionalismo na visão eclética desenvolvida no Brasil) em relação aos aspectos econômicos subjacentes às políticas públicas, no caso, a gratuidade das passagens de transporte público urbano.

O terceiro capítulo caracteriza a mobilidade urbana como problema jurídicoeconômico, com críticas a abordagem defendida pela Análise Econômica do Direito (AED) e ênfase na abordagem chamada Análise Jurídica da Política Econômica (AJPE), cuja metodologia será utilizada na análise da Política de Mobilidade Urbana de duas Regiões Administrativas do Distrito Federal: (i) a Região Administrativa de Vicente Pires e (ii) a Região Administrativa de Águas Claras. Deve ser salientado que a análise das políticas nas 
regiões indicadas é feita explicitamente em caráter exemplificativo da aplicação dos critérios e estratégias analíticos da AJPE como alternativa ao tratamento tanto dogmático quanto neoconstitucionalista de questões referentes à efetividade do direito de ir e vir no Brasil.

Por fim, a dissertação propõe sugestões de reforma das políticas públicas de mobilidade desenvolvidas nas cidades supramencionadas e apresenta as conclusões da pesquisa realizada. 


\section{HISTÓRICO DA LEGISLAÇÃO DOS TRANSPORTES E DA MOBILIDADE URBANA NO BRASIL}

\subsection{Do Período Imperial até o Início da Era Vargas}

\subsubsection{Observações iniciais}

Neste capítulo é oferecido um breve histórico da legislação referente aos transportes no Brasil, especialmente os transportes terrestres de tração mecânica; ressalta-se, desde já, que não se tem a pretensão de esgotar o assunto. O propósito é formar uma percepção sobre a evolução dos objetivos e desafios da política de transporte no Brasil. Como se verá, desde o início, os aspectos econômicos e financeiros formam partes importantes de qualquer esforço de elaboração ou reforma da política de transporte no país.

\subsubsection{O ferroviarismo e o Brasil rural}

A oferta de infraestrutura no período colonial não era concebida como função pública, mas sim privada, sujeita à autorização da Coroa Portuguesa que não tinha interesse em estabelecer sistemas de comunicação entre as capitanias e, por vezes, impedia a abertura de vias (LIMA NETO, 2001, p. 84-87) ${ }^{8}$

Com a independência, cresceu a necessidade de se impulsionar a economia do império através do desenvolvimento de uma infraestrutura de transportes praticamente inexistente. ${ }^{9}$ Outorgada em 1824, sob influência liberal, a Constituição do Império não trouxe

\footnotetext{
8 No tocante aos meios transporte, Lima Neto (2001, p. 86) ressalta que "[t]rezentos anos não deixaram um grande herança em termos de infra-estrutura, conforme se pode ler em relatos de diversos viajantes estrangeiros que cruzavam o País durante o reinado de D. João VI (Coimbra 1974, em que se sistematizam as observações feitas por Saint-Hilaire, Koster, Maximiliano, Pohl, Martius e Luccock.) As vias, na verdade picadas, eram estreitas e mal mantidas e intransitáveis durante os períodos de chuva. Só em trechos custos os viajantes poderiam se beneficiar de algum calçamento."

${ }^{9}$ A falta de infraestrutura de transportes "dificultava toda a vida econômica. A região permanecia fechada numa economia de subsistência que mal dava para seu consumo próprio e a exportação se tornava impossível: frequentemente o preço do frete era maior do que o produto" (VIOTTI DA COSTA, 1998, p.207 apud ACIOLI, 2007, p. 21)
} 
dispositivos que tratassem especificamente da prestação dos serviços de transportes. Com a edição da Lei de 29 de Agosto de 1828, foram estabelecidas as regras para a construção das obras públicas que objetivassem promover a navegação de rios, abertura de canais, edificação de estradas, pontes, calçadas e aquedutos. Segundo esta lei, os empresários nacionais ou estrangeiros poderiam atuar associados em companhia ou individualmente.

A Lei de 1828, também conhecia como Lei José Clemente (Senador do Império), estabeleceu a competência do Ministro e Secretário de Estado dos Negócios para determinar a realização de obras quando estas beneficiassem mais de uma província. Segundo a mesma lei, a competência seria dos Presidentes (atualmente Governadores de Estado), juntamente com o Conselho da Província, quando o benefício alcançasse apenas uma província e, por fim, das Câmaras Municipais, se os benefícios estivessem circunscritos aos limites das cidades.

De acordo com a Lei de 1828, após a definição das obras a serem executadas, o respectivo orçamento e planejamento deveriam ser elaborados por engenheiros ou "outra pessoa inteligente". A referida documentação deveria ser fixada em locais públicos próximos à localidade onde seriam realizadas as obras pelo período de seis meses, convidando-se os cidadãos a fazerem as observações e reclamações pertinentes. Depois da aprovação dos planos, as construções seriam oferecidas, por meio de editais, aos empresários nacionais ou estrangeiros; havendo mais de um interessado, a obra seria entregue a quem apresentasse a oferta mais vantajosa.

A Lei de 1828 , em seu art. $8^{\circ}$, já previa a cobrança de valores diferenciados para as "taxas", conforme o uso da infraestrutura de transporte, in verbis:

\footnotetext{
Art. $8^{\circ}$ Ao fixar-se o quantitativo da taxa cobrável de cada pessoa, que usar da obra, haverá a necessária differença, quanto às estradas, pontes, e calçadas, entre pedestres, e cavalleiros, as differentes especies de animaes, e os differentes vehiculos, que por estas passarem; quanto aos rios, e canaes, entre barcos maiores e menores; e quanto aos aqueductos das aguas para uso das povoações (cuja taxa se cobrará por fogos), entre o maior, e menor consumo, que cada casa fizer, tendo-se sobretudo em vista as possibilidades, e circumstancias dos moradores.
}

Os empresários, que estavam obrigados a cumprir o cronograma estabelecido em contrato sob pena de multa, somente poderiam cobrar a "taxa" de uso após a conclusão das obras, cuja conservação, durante a vigência do contrato, era de sua responsabilidade. Finda a vigência contratual, a autoridade poderia realizar novo contrato com aquele que oferecesse maiores vantagens. Caso não houvesse empresários interessados, as obras deveriam ser 
realizadas por conta dos rendimentos dos Conselhos ou da Fazenda Pública, conferindo-lhes os mesmos direitos à cobrança da taxa de uso ou passagem.

A Lei previu, ainda, o direito à indenização pelas benfeitoras e pelo solo aos proprietários cujos terrenos fossem afetados pela abertura de estradas ou pelas obras; e previu isenção da cobrança de taxa daqueles que utilizassem a infraestrutura em razão da prestação de serviço à Nação.

Em 1835 foi editado o Decreto $\mathrm{n}^{\circ} 101$ de 31 de outubro por meio do qual o Governo concedia, a uma ou mais companhias que construíssem a estrada de ferro ligando a Capital do Império (Rio de Janeiro) até as capitais das províncias de Minas Gerais, Rio Grande do Sul e Bahia, o privilégio exclusivo de uso de carros para transporte de gêneros e pessoas pelo prazo de 40 anos ${ }^{10}$. As companhias seriam obrigadas a construir novas estradas nos lugares onde cortassem as já existentes, sem poder cobrar qualquer taxa por isso. O Governo poderia, ainda, conceder os mesmos privilégios assegurados à Companhia do Rio Doce indicados no Decreto $\mathrm{n}^{\circ} 24$ de setembro de 1835. O Governo designaria as cidades e vilas onde as companhias deveriam atuar; estas, contudo, estavam livres para definir a melhor forma de execução. $^{11}$

Em 1845, a primeira ferrovia do Brasil, instalada ao fundo da Baía da Guanabara (atual município de Magé/RJ), foi inaugurada por Irineu Evangelista de Souza (Barão de Mauá), a estrada de ferro contava com $14,5 \mathrm{Km}$ de extensão. ${ }^{12}$

O modelo adotado até então, baseado na concessão pura atribuída ao proponente que apresentasse a melhor oferta, não obteve o êxito esperado. A despeito da participação inglesa na Recife and São Francisco Railway Company que ligava o Recife ao Cabo (Pernambuco), o

\footnotetext{
${ }^{10}$ Antes do Decreto $\mathrm{n}^{\circ} 101 / 135$ foi editado o Decreto $\mathrm{n}^{\circ} 24$ de setembro de 1835 , por meio do qual o governo imperial concedeu à Companhia do Rio Doce, pelo prazo de 10 (dez) anos, o privilégio exclusivo para navegar por meio de barcos a vapor ou superior pelo Rio Doce, afluentes e pelos Rios que banhassem as capitais do império e a província da Bahia. Embora a navegação naqueles rios continuasse livre, o decreto conferia à companhia o direito de cobrar "taxas" pela passagem por obras realizadas por esta como pontes, canais e estradas. As taxas seriam estabelecidas pela companhia e poderiam ser arrecadas pelo prazo de 40 anos; findo o prazo, o governo poderia "remir" as obras pelo valor estabelecido por árbitros ou prorrogar o prazo por mais 40 anos, sem indenização para a companhia. Esgotado o prazo da prorrogação, a companhia deveria entregar as obras em bom estado. O Decreto $\mathrm{n}^{\circ}$ 101/1835 estendeu aos demais interessados os mesmos benefícios do Decreto $n^{\circ} 24 / 1835$.

${ }^{11}$ Conforme ressalta Acioli (2007, p.8), "[a] concessão era o instrumento preferido, mas se não houvesse interessados para as obras o governo se encarregaria da construção, mas cobraria dos usuários sua utilização, conceito muito semelhante a ideia moderna de PPPs."

12 Cronologia da instalação da malha ferroviária no Brasil elaborada pela Associação Nacional dos Transportadores Ferroviários (ANTF). Disponível em <http://www.antf.org.br/index.php/informacoes-dosetor/cronologia-historica-ferroviaria $>$ Acesso em 20 out. 2014.
} 
Decreto $\mathrm{n}^{\circ} 101$, de 31 de outubro de 1835, não logrou atrair o capital necessário para a implementação do sistema ferroviário ${ }^{13}$, pois diversos países já estavam oferecendo além do pagamento das tarifas, também benefícios adicionais, em especial a garantia de juros. Sem que prática semelhante fosse adotada no Brasil, as perspectivas de investimentos estrangeiros no setor não seriam muito promissoras. Neste sentido, Acioli (2007, p.12) observa:

“[D]ificilmente os capitais europeus seriam atraídos para o Brasil. Naquela época outros países, dentre os quais a Rússia, haviam igualmente adotado o sistema de garantias. (...) não restava outro caminho que não fosse o de acompanhar as nações europeias no alargamento das vantagens concedidas às empresas ferroviárias."

Embora a política de concessão pura não tenha logrado êxito em ampliar a malha ferroviária, a Lei José Clemente (1828) foi o marco legal não apenas para a política de concessões, mas também para a concepção da divisão de competências (posteriormente adotada na República), para a política de cobrança diferenciada de tarifas e taxas e, sobretudo, para a exploração do terreno como meio para se calcular o retorno de um investimento em infraestrutura. Em muitos casos, ressalta Acioli, a exploração do terreno se mostrava mais interessante do que a obra em $\mathrm{si}^{14}$

Além das garantias concedidas aos investidores estrangeiros, a partir de 1850, com o fim do período da regência e a coroação de Pedro II, a situação política do país tornou-se mais estável. A proibição do tráfico de escravos liberou capital, até então empregado na escravidão, para outros setores econômicos.

A partir da década de 70 do século XIX foram editadas leis tratando da concessão de garantia de juros. A Lei $\mathrm{n}^{\circ} 2.450$, de 24 de setembro de 1873, instituiu o regime de subvenção quilométrica e garantia de juros às companhias que construíssem estradas de ferro de acordo com a Lei $n^{\circ}$ 641, de 26 de junho de 1852. As medidas, inicialmente, eram excludentes: o

\footnotetext{
${ }^{13} \mathrm{O}$ benefício de concessão da terra para construção da obra de infraestrutura, previsto no Decreto de 1835 , era semelhante aos benefícios concedidos pelo governo norte-americano. Segundo MOREIRA (2005, p. 129 apud Acioli, 2007, p.11) "[...] as concessões de terras para ferrovias atingiram proporções colossais de 1850 a 1872 o congresso deu 155 milhões de acres de domínio público para empresas de ferrovias diretamente ou através de estados. Uma parte considerável consistia em terras contendo minerais valiosos, carvão, madeira e terra agricultável.' [...]Embora esse sistema tenha permitido um crescimento notável das ferrovias norte-americanas, o mesmo não se verificou no Brasil, onde 'a iniciativa privada' (grifo do autor) passaria a demandar benefícios adicionais."

14 Também nos EUA, a concessão das terras algumas vezes se mostrava tão mais lucrativa que os empresários postergavam ao máximo a entrega das obras, procurando convencer as novas legislaturas a respeito da necessidade de reajuste dos valores acertados para a realização do empreendimento, segundo MOREIRA (2005, p.116 apud ACIOLI, 2007, p.9), “[m] uitas das construtoras de canais tão ricamente agraciadas pelo governo com grandes extensões de terras, prestaram pouca atenção na construção dos canais propriamente dita."
} 
governo poderia conceder subvenção quilométrica ou juros limitados a $7 \%$ ao ano, correspondente ao capital empregado no limite de 30 anos. Tais medidas somente seriam concedidas pela construção de estradas que servissem como principal comunicação entre os centros produtores e os de exportação, sendo concedido apenas um dos referidos benefícios por província, enquanto as estradas de ferro não garantissem o retorno do investimento.

Complementando as medidas supramencionadas, foi editado o Decreto $\mathrm{n}^{\circ} 6.995$, de 10 de agosto de 1878. De acordo com esta norma, as tarifas, e não mais "taxas", seriam organizadas pelas companhias e aprovadas pelo governo, não podendo exceder as taxas dos transportes por meios ordinários (transporte marítimo ou terrestre por tração animal). $\mathrm{O}$ Decreto estabelecia, ainda, o abatimento de 50\% das tarifas para autoridades, munição de guerra, colonos imigrantes e seus utensílios, as sementes destinadas gratuitamente pelo governo aos lavradores, nos casos de socorro decorrente de seca, inundações e calamidades públicas.

No Brasil agrário do século XIX, diferentemente dos Estados Unidos da América (EUA), havia pouco ou nenhum interesse na instalação da malha ferroviária em áreas mais distantes ou desabitadas. A malha ferroviária no Brasil percorria as regiões economicamente ativas, visando essencialmente o transporte das mercadorias agrícolas, principalmente o algodão e o café. A escolha dos lugares para a construção das estradas de ferro pode ser explicada pela origem do capital utilizado no financiamento do empreendimento. ${ }^{15}$,

De acordo com Eichengreen (1994, p.6), nos Estados Unidos da América, o financiamento floresceu primeiramente nas áreas de manufatura. Em New England, centro da manufatura têxtil dos EUA no início do século XIX e também centro comercial, de navegação e pesca da baleia, grande parte do financiamento foi levantado por meio de contatos comerciais e familiares. A maior parte das ações da nova ferrovia New England foram subscritas por industriais locais, fazendeiros, donos de terras, banqueiros, comerciantes e empreiteiros com acesso à informação e que se beneficiavam com as redes de transporte, razão pela qual a ferrovia de New England foi quase totalmente financiada por recursos obtidos na própria localidade.

\footnotetext{
${ }^{15}$ Sobre esse assunto Nassif (2004 apud Acioli, p. 15) explica: “com as restrições ao comércio escravagistas, os bancos londrinos interrompem as operações com clientes que tivessem alguma ligação com o trabalho escravo. É esse movimento que permite aos cafeicultores paulistas substituir os escravagistas como parceiros preferenciais da banca internacional e se tornar os novos donos da liquidez nacional. O modelo era o mesmo. Depositavam em bancos ingleses, que emprestavam ao Brasil. Os recursos eram aplicados nas PPPs da época, serviços públicos, estradas de ferro, com remuneração garantida e vantagens escandalosas. Cada empreendimento permitia à Inglaterra inundar o país com consultores, insumos, que entravam sem pagamento de taxas."
} 
Ainda segundo Eichengreen, o modelo de financiamento local, contudo, tinha grandes dificuldades em se generalizar em razão da ausência de capital, posto que nem todas as cidades norte americanas contavam com o mesmo grau de desenvolvimento à época. A solução encontrada foi atrair investidores de outras regiões dos Estados Unidos e também estrangeiros. Os investidores estrangeiros eram intermediados por instituições especializadas que prosperavam na Europa. Os instrumentos de financiamento variavam de acordo com a situação econômica e a distância do empreendimento, motivo pelo qual as garantias fornecidas pelo governo foram particularmente importantes para atrair investidores estrangeiros para os lugares mais distantes e desabitados,

De acordo com o referido autor, embora as garantias prestadas pelo governo tenham sido fundamentais no desenvolvimento dos sistemas de transporte, tais medidas tiveram consequências muitas vezes desfavoráveis, entre elas se destacam: o aumento dos custos do empreendimento e a redução dos meios de controle pelos investidores que consideravam que parte de seus lucros já estaria assegurada, se descuidando do controle das companhias. ${ }^{16}$ Considerando o histórico dos investimentos em infraestrutura das ferrovias no século XIX, Eichengreen (1994, p.17) conclui que a atuação efetiva por parte da administração pública, por meio de agência reguladora capaz de monitorar o mercado e aplicar as sanções cabíveis, seria uma das principais formas de se ultrapassar as falhas de mercado.

No Brasil imperial, de acordo com Renê Schoppa (2004, p.68), a impressão de que os empresários privados somente tinham interesse nos lucros imediatos, sem qualquer preocupação com o interesse público ou com o desenvolvimento regional, era evidente.

\footnotetext{
${ }^{16}$ Nas palavras de Eichengreen (1994, p.17): "The implication is that exploiting non traditional approaches to financing infrastructure investment requires two further initiatives on part the policymakers. First, the effectiveness of public administration must be enhanced. Effective public oversight is need insure the accountability of enterprises, since private investors will have little interest in that accountability if they enjoy government guarantees. The agencies concerned will have to monitor management decision-making and firm financial performance and credibly threaten legal actions against managers tempted by bankruptcy for profit. Second, policymakers need to encourage the development of financial institutions such as investment banks, mutual funds and bond-rating agencies capable of surmounting information problems in order to free the government of the need to provide and interest guarantees." (Tradução nossa) As implicações das abordagens não tradicionais para financiamento de investimentos em infraestrutura requer duas iniciativas por parte dos formuladores da política. Primeiro, a atuação da administração pública deve ser evidenciada. A fiscalização efetiva é necessária para assegurar a "accountability" do empreendimento, uma vez que os investidores privados teriam pouco interesse a respeito, caso gozem de garantias concedidas pelos governos. As agências teriam a atribuição de monitorar as decisões e a performance financeira e as ameaças a credibilidade em razão do ajuizamento de ações contra administradores com vistas a obter lucro em razão da falência. Segundo, os formuladores da política precisam, encorajar o desenvolvimento de instituições financeiras, tais como bancos de investimentos, fundos mútuos e agências de classificação de riscos capazes de antecipar informações visando livrar o governo da necessidade de aumentar as garantias já prestadas.)
} 
Além do mais, as dificuldades com relação ao financiamento das ferrovias brasileiras, enfrentadas no período imperial, se agravaram com a república, cujo início foi marcado por falências e pela encampação de várias ferrovias pelo governo. Os problemas financeiros que atingiram as ferrovias tiveram sua origem na crise sofrida pelo setor cafeicultor a partir do final do século XIX e foram agravados pela política de Encilhamento ${ }^{17}$.

Diante da escassez de crédito, o governo terminou por encampar diversas estradas de ferro tendo em vista que o custo da encampação era inferior ao da prestação de garantia de juros. De acordo com Renê Schoppa (2004, p.67), o Governo de Campos Sales (1898-1902), em razão da incapacidade do país em cumprir os compromissos da dívida externa, negociou novo plano com os banqueiros ingleses, esse plano consistia no rolamento da dívida externa e de algumas garantias de juros, ao mesmo tempo em que o governo brasileiro conseguia obter nova operação de crédito e trocar os contratos de garantia de juros por títulos de renda fixa.

Ainda segundo Schoppa (2004, p. 67), para Campos Sales, a encampação seria medida temporária, pois para este não haveria vantagem financeira em manter as ferrovias sob a administração pública. Com a edição da Lei nº 741, de 26 de dezembro de 1900, que tratava da receita geral da República, o governo federal foi autorizado a arrendar ou alienar as estradas de ferro, aplicando o produto na reorganização financeira do país. Esse processo de retorno das estradas ao setor privado possibilitou a formação de enormes companhias ferroviárias estrangeiras, dentre as quais se destaca a Brazil Railway Company controlada por Percival Farquhar que em 1912 passou a controlar 60\% da malha ferroviária brasileira. (SCHOPPA, 2004, p.67-68)

A Constituição de 1891, em seu artigo 13, manteve a competência da União e dos Estados para legislarem sobre viação férrea e navegação interior, a divisão de competências seria regulada por meio de lei federal.

Em 1912 foi editado o Decreto Legislativo $n^{\circ} 2.681$, conhecido como a Lei das Estradas de Ferro, que representou um marco no reconhecimento dos direitos dos passageiros e da responsabilidade civil dos concessionários de serviço de transporte no país. O contrato de

\footnotetext{
${ }^{17}$ A Política de Encilhamento instituída pelo Decreto de 17, de janeiro de 1890, previa empréstimos à lavoura e autorizava a utilização de créditos públicos como cobertura para a sua emissão. Os bancos foram autorizados a emitir dinheiro mediante a garantia de apólices da divida pública. "O privilégio dos bancos emissores provocou pressões contrárias levando o governo a permitir o credenciamento de outros estabelecimentos para emitir dinheiro", essa medida provocou um aumento da emissão de papel moeda acima das necessidades econômicas da sociedade, com o tempo surgiram sociedades comerciais cujas ações eram negociadas na bolsa sem qualquer garantia, a não ser a promessa de que serviriam de lastro para um futuro empreendimento industrial. $O$ resultado da política monetária expansionista foi o aumento da especulação, da inflação e o descalabro financeiro. Fonte: IPEA. Revista Desafios do Desenvolvimento, 2011. Disponível em http://www.ipea.gov.br/desafios/index.php?option=com content\&view=article\&id=2490:catid=28\&Itemid=23 > Acesso em 16 fev. 2015
} 
transporte ferroviário serviu de modelo para os juristas que nele vislumbraram a "cláusula de incolumidade". De acordo com Sérgio Cavalieri Filho (2008, p.296), a cláusula de incolumidade consigna a obrigação do transportador em garantir a segurança dos passageiros desde a origem até o destino, o descumprimento desta obrigação gerava o dever de indenizar, independente da comprovação da culpa do transportador.

Antes da edição da Lei de Estradas de Ferro, o viajante precisava provar a culpa da companhia; com a edição da nova lei, em razão da cláusula de incolumidade, a vítima fícou dispensada de produzir a prova em razão da presunção de que a ocorrência do acidente seria resultado de uma falha contratual ensejadora de responsabilidade civil do transportador. $\mathrm{O}$ transportador somente se eximiria da responsabilidade se conseguisse comprovar que a inexecução do contrato teria ocorrido por motivo de força maior, caso fortuito ou por culpa da vítima. (2008, p.297)

O contrato celebrado com uma companhia ferroviária contém os mesmos elementos dos demais contratos de transporte, pois as características dos contratos são as mesmas e também são idênticas as suas finalidades, apenas o que diferencia são os meios de transporte, bondes ou ônibus. A Lei das Estradas de Ferro, segundo Sérgio Cavalieri Filho (2008, p.296), encampou a doutrina mais atualizada da época, ao transferir o ônus da prova do passageiro, para o transportador. Embora destinada a regular apenas a responsabilidade civil da rede ferroviária, a Lei das Estradas de Ferro foi sendo aos poucos aplicada analogicamente aos demais meios de transportes terrestres à medida que foram surgindo, conseguindo se manter em vigor por quase um século! Conforme observa Cavalieri:

O Judiciário fez com que a Lei das Estradas de Ferro aquilo que Boulanger chamava de 'poder de rejuvenescimento das leis; poder que consiste em fazê-las viver seguindo ou atendendo às exigências do tempo presente. (CAVALIERI, 2008, p. 296)

O Decreto $\mathrm{n}^{\circ} 15.673$, de 7 de setembro de 1922, que aprovou o Regulamento para a Segurança, Política e Tráfego das Estadas de Ferro, determinou a necessidade de instalação de sanitários em número suficiente para funcionários e passageiros (art.42), estipulando, ainda, que o material rodante deveria ser construído seguindo condições de segurança e comodidade para os passageiros. 
Ao mesmo tempo em que a legislação dos transportes ferroviários no tocante aos direitos e bem estar dos passageiros se modernizava, o modal em si começava a perder lentamente seu espaço na política de transportes para o transporte rodoviário.

O interesse decrescente pelas ferrovias pode ser explicado pela redução dos recursos empregados pelos bancos ingleses. A Inglaterra que era, ao mesmo tempo, maior financiadora da instalação da malha ferroviária no Brasil e maior fabricante de equipamentos ferroviários desde o século XIX, após a Primeira Grande Guerra Mundial e, principalmente, após a Segunda, começou a ver declinar sua influência financeira. $\mathrm{O}$ enfraquecimento inglês ocorreu ao mesmo tempo em que os Estados Unidos, grande financiador da indústria de automóveis, emergiram como nova potência econômica. (Lima Neto, 2001, p.178-179 e 222)

No Brasil, um dos maiores entusiastas do transporte rodoviário foi o Presidente Washington Luís (1926-1930) que em 1927 criou o Fundo Especial para Construção e Conservação de Estradas de Rodagem, cujos recursos provinham da arrecadação de impostos sobre o preço da gasolina, dos veículos e dos pneus ${ }^{18}$. É de Washington Luís, inclusive, a célebre frase: “Governar é abrir estradas.” (LIMA NETO, 2001, p.178-179 e 223)

Em 1925, o jornal O GLOBO destacava o aumento dos congestionamentos decorrentes do crescimento das importações de automóveis. Segundo o referido jornal, em um ano o número de veículos passou de 2.772 para 12.995, as importações de combustível também dispararam. ${ }^{19}$. Em razão do aumento da circulação de veículos automotores, o Presidente Washington Luis (1926-1930) editou o Decreto n 18.323, de 24 de julho de 1928, que aprovou o regulamento para a circulação internacional de automóveis no território brasileiro e para a sinalização, segurança do trânsito e polícia das estradas de rodagens.

\footnotetext{
${ }^{18}$ De acordo com Lima Neto (2001, p.223), a partir de 1930 o fundo começou a apresentar déficit, razão pela qual foi extinto em 1931, passando o setor de transportes a depender de dotações orçamentárias, o que representava um entrave na expansão da malha rodoviária.

${ }^{19}$ A respeito da chegada do automóvel ao Brasil, colaciona-se a seguinte matéria jornalística: "Na época um indicador de progresso, há quase 90 anos a primeira página do jornal O GLOBO trazia uma surpresa para os brasileiros na sua edição de estreia. Em 29 de julho de 1925, o jornal noticiava o 'assombroso aumento do número de automóveis' no país. Em apenas um ano, de 1922 para 1923, o salto havia sido de 2.772 para 12.995 automóveis. Os dados do crescimento das importações de carros eram do "serviço de informações" do Ministério da Agricultura. [...] No Rio de Janeiro então capital da República, de poucos veículos poluindo ruas e avenidas arborizadas, o consumo de combustíveis também era motivo de orgulho. Na sua primeira edição, o jornal informava que as importações de gasolina e óleo combustível haviam aumentado vertiginosamente em sete anos. Em 1918, o Brasil importava 12.438 toneladas de gasolina, número que pulou para 100.500 toneladas em 1925. No caso do óleo, as compras no exterior passaram de apenas 152 toneladas para mais de 36 mil.htm." Disponível em < http://Em 1925, Brasil vive 'assombroso aumento' do número de automóveis Acervo > Acesso em 31 de out. de 2014.
} 
A circulação dos automóveis importados, pois não havia ainda produção nacional, estava condicionada a sua apresentação às autoridades brasileiras que deveriam verificar as condições de segurança e a presença de "aparelhos" obrigatórios (buzina, sistema de freios, espelhos retrovisores, etc). Os condutores de veículos, estrangeiros ou nacionais, deveriam se submeter às leis brasileiras.

Deste modo, a valorização do transporte rodoviário e suas consequências começaram a ser sentidas na capital da República, ao mesmo tempo em que a concepção do automóvel como símbolo da modernidade para o país começava a ganhar força.

\subsubsection{Os bondes elétricos e o início da expansão urbana}

A chegada do bonde ${ }^{20}$ elétrico em cada capital do país possui características específicas, cujo relato escapa aos objetivos desta dissertação; a importância do bonde elétrico no histórico da política de transporte no Brasil, contudo, revela a necessidade de incluí-lo neste capítulo, ainda que de forma resumida, de modo a situar o leitor nos aspectos gerais deste que foi de fato o primeiro modal de transporte coletivo essencialmente urbano do Brasil (excetuando os movidos por tração animal). Feitas estas considerações, passa-se ao breve relato do histórico dos bondes nas cidades do Rio de Janeiro, então capital da República, e de São Paulo, grande produtor e exportador agrícola do século XIX.

A chegada da família real em 1808 provocou mudanças na cidade do Rio de Janeiro que até então era uma cidade essencialmente portuária. A cidade, apesar de ser a maior do país no século XIX, continuava com características tipicamente coloniais, com suas ruas estreias, sinuosas, a maioria sem pavimentação e cheias de buracos. Os congestionamentos entre a zona portuária, o terminal ferroviário e o centro mercantil eram frequentes. A família real se instalou no velho arraial de São Cristóvão, distante vários quilômetros do litoral, determinando a melhoria no acesso à região ${ }^{21}$.

O transporte, ainda por tração animal, era feito por tílburis ou caleches, veículos individuais ou para poucas pessoas; gôndolas, veículos coletivos com capacidade para nove

\footnotetext{
${ }_{20}$ "Bonde" é o termo utilizado em muitas cidades brasileiras no lugar de carris, palavra portuguesa para tramways." (WEID, 1994, p.1).

${ }^{21}$ Cf. WEID, 1994, p.5.
} 
passageiros puxados por parelhas de bestas, e as carruagens, puxadas por quatro cavalos. Existiam também os ônibus, veículos constituídos por quatro carros fechados de dois andares puxados por quatro cavalos, funcionavam precariamente em razão do número reduzido. Os ônibus, que concorriam com as gôndolas, duraram até a chegada dos bondes. O transporte de carga era feito por carroças. (SANTOS, 1934, p.232-260)

O início da instalação dos trilhos para os bondes, ainda puxados à tração animal, sofreu com mesma falta de crédito já experimentada pelo transporte ferroviário e, conforme já ocorrera com as estradas de ferro, o capital para a instalação do sistema de bondes também foi conseguido no exterior.

A dificuldade em se obter crédito, de acordo com Noronha Santos (1934, p. 250), tinha sua origem não apenas na escassez de capital, mas também na descrença na instalação da rede de bondes. Além das dificuldades financeiras, Noronha Santos (1934, p.250) ressalta a oposição das "senhoras" em misturar-se às classes mais pobres, o que ocorreria com a implementação dos bondes. Segundo o referido autor, por trás da "campanha reacionária" promovida pelas "senhoras" estavam as companhias de ônibus e gôndolas, que até então realizam o transporte na cidade e que, fatalmente, perderiam espaço para o novo meio de transporte.

Solucionada a questão do crédito, conseguido no exterior pelo Barão de Mauá e pelo americano Charles B. Greenough, a Botanical Garden Rail Road Company constituída pelos referidos empresários e cuja concessão para o transporte de passageiros foi obtida por meio do Decreto $n^{\circ} 3.738$, de 21 de novembro de 1866, iniciou naquele mesmo ano as instalações dos trilhos obtendo grande sucesso no decorrer dos anos. ${ }^{22}$ (SANTOS, 1934, p.250)

De acordo com Dunlop apud Weid (1994, p.9), foi nesta época que o termo "bond" passou a identificar o novo tipo de transporte. O termo tem sua origem em um sistema de bloco de cinco passagens criado pela Botanical Garden para facilitar o troco, visto que as moedas no valor da passagem eram raras. Os blocos eram vendidos nas estações e nas passagens, em cima do nome da companhia estava escrita a palavra "bond" (título em Inglês),

\footnotetext{
22 O entusiasmo foi descrito por Noronha Santos (1934, p. 251-252) nos seguintes termos: "estabelecida a primeira linha de bonds, o enthusiasmo dominou certo grupo de homens de negócios. Crearam-se linhas e travou-se luta encarniçada contra os omnibus e especialmente, contra as gondolas. Contrariando uma pretensão da companhia das Gondolas Fluminenses, na Camara dos Deputados, o Dr. Candido Torres Filho qualificou de absurdo o systema de locomoção, vaticinando também a ruina dos segeiros. Verberou aquelle ilustre representante do povo o abuso dos omnibus (já desaparecidos do centro da cidade) e das gondolas, danificando o calçamento e, além disso, ocasionando desastres. [...] Empobrecida e ridicularizada, e na impossibilidade material de se opor à concorrência avassaladora das empresas de carris, a Companhia das Gondolas Fluminenses deu por fim sua missão. [...] O bond ao nascer, limitou despoticamente a esfera de acção de outros vehiculos.”
} 
o valor e um desenho do veículo. Com o tempo, o povo, por analogia, passou a denominar o veículo pelo termo constante na passagem, o que se generalizou rapidamente.

O sucesso da Botanical Garden provocou a criação de novas empresas que se formaram mais ou menos na mesma época. Em 1868, o Barão de Rio Negro e Quintino Bocaiuva foram autorizados pelo governo imperial a reativar o serviço da Companhia de Ferro da Cidade à Boavista, cuja concessão caducara. Em janeiro de 1869, Quintino Bocaiuva transferiu a concessão para seu amigo Bernardo Caymari, industrial de origem cubana. Ao mesmo tempo, Silvester S. Battin e Alberto Hagger, dois capitalistas norte-americanos, conseguiram a transferência das concessões de Charles Morsing e Bernardo Caymari e formaram uma companhia em Nova York que obteve autorização para funcionar no Brasil com o nome de The Rio de Janeiro Street Railway Co., também em 1869. Alguns anos depois, em 1873, a empresa foi adquirida por capitalistas brasileiros e passou a se chamar companhia Ferro-Carril de São Cristóvão. (WEID. 1994, p.10)

De acordo com Weid (1994, p.11), o sucesso das Companhias do Jardim Botânico e de São Cristóvão revelam duas características comuns no desenvolvimento das empresas de bondes no Rio de Janeiro, quais sejam: a dependência do capital estrangeiro para o seu estabelecimento e a alta lucratividade do empreendimento. As duas empresas somente conseguiram ser constituídas após o aporte do capital estrangeiro, a nacionalização ocorreu quando conseguiram se impor e expandir suas redes de transportes.

Conforme destaca Weid (1994, p.10), um empreendimento tão lucrativo rapidamente tornou-se bastante cobiçado, suscitando um imenso número de pedidos de concessão que deram origem a inúmeras pequenas empresas que lutavam ferozmente pelo espaço urbano. A concorrência desenfreada provocou a generalização do processo de fusão de companhias, em uma tendência à monopolização gerando de forma explícita ou implícita o privilégio de zona, id. est., a área compreendida pela concessão de uma companhia não podia ser atendida por outra.

Em São Paulo, a chegada do bonde serviu para garantir a mobilidade de fazendeiros e comerciantes de café. Apesar da integração das fazendas de café e da inauguração da primeira estação de trem de passageiros na região da Luz em 1867, à época fora dos limites da cidade, o transporte dos passageiros da estação até o centro de São Paulo continuava sendo feito por tílburis. O aumento no fluxo de pessoas à capital da província, contudo, trouxe a 
necessidade de se criar um sistema mais regular de passageiros, o que foi atendido pelos bondes, incialmente puxados por tração animal. ${ }^{23}$

No início do século XX, enquanto a eletrificação na cidade do Rio de Janeiro começava a ser implementada aos poucos, a cidade de São Paulo já contava com veículos elétricos em virtude da concessão recebida pela The São Paulo Tramway, Light and Power Company ou, simplesmente, Light. Os bondes elétricos que começaram a circular no início do século XX transformaram a paisagem das cidades. Insta ressaltar que embora a instalação dos trilhos tenha sido bem sucedida, foi a chegada do bonde elétrico que representou uma verdadeira reforma urbana, pois possibilitou a expansão das cidades para além dos centros. ${ }^{24}$

A concessão do bonde, meio de transporte essencialmente urbano, estava inserida na competência dos governos locais que enfrentavam a pressão não apenas dos empresários nacionais, mas também do capital estrangeiro. Foi neste contexto que os empresários canadenses Frederick S. Pearson e Alexander Mackenzie, conhecedores do potencial e das condições urbanas do Rio de Janeiro, se envolveram no projeto de eletrificação do país. (WEID, 1994, p.20)

Enquanto o bonde elétrico continuava ganhando espaço, o serviço de bonde puxado por tração animal, que atendia a população urbana menos favorecidas das cidades sofreu considerável redução dos investimentos ao longo dos anos. Apesar do contingente de usuários do bonde ter aumentado em $132 \%$ entre 1890 e 1905, o número de veículos aumentou apenas $34 \%$ neste mesmo período. Os bondes puxados à tração animal, sempre lotados, faziam parte do cotidiano das cidades, conforme relatos dos jornais da época. (TERRA, 2012, p.238)

Acrescentem-se às péssimas condições do transporte também as medidas adotadas pelo governo imperial que, em 1879, aprovou a criação de uma taxa no valor de 20 réis a ser cobrada nas passagens de bonde. A medida foi recebida com duras críticas da imprensa e da população, que acusavam o governo de tentar cobrir déficit orçamentário com recursos das passagens. A indignação da população aumentou quando foi autorizado o uso da força policial contra aqueles que se recusassem a pagar o acréscimo. Após muitos protestos, a cobrança do imposto foi cancelada. (TERRA, 2012, p.245)

\footnotetext{
${ }^{23}$ De acordo com reportagem de Ayrton Camargo e Silva que trata do ocaso dos bondes: Disponível em < http://www2.uol.com.br/historiaviva/reportagens/a_morte_do_bonde.html > Acesso em 08 de jan.2015.

${ }^{24}$ Cf. WEID, 1994, p. 12.
} 
Enquanto os investimentos nos bondes puxados por tração animal diminuíam, os bondes elétricos experimentavam grande expansão. A expansão do bonde elétrico foi capitaneada por Pearson e Mackenzie que já estavam estabelecidos em São Paulo. Este fato, contudo, ao invés de facilitar o acordo, dificultou a aceitação de sua proposta. Segundo Weid, (1994, p.20) os políticos e administradores do Distrito Federal, à época o Rio de Janeiro, estavam atentos à tendência de formação de monopólio nos transportes urbanos, o que já ocorria na iluminação pública e privada que estavam nas mãos de uma única empresa estrangeira. Em razão disso, o poder municipal procurou evitar essa tendência ao monopólio por meio da edição do Decreto n ${ }^{\circ} 1001$, assinado pelo prefeito Pereira Passos em 1904, que proibia privilégios exclusivos para produção e distribuição de energia elétrica na capital da República.

Os empresários canadenses quase se desanimaram com o advento do Decreto $\mathrm{n}^{\circ}$ 1001, mas o Rio de Janeiro, no início do século XX, era uma cidade em transformação, obras estavam sendo realizadas por toda a parte visando tornar o Distrito Federal uma cidade moderna e cosmopolita. As companhias de bondes que estavam instaladas no Rio aproveitavam essas obras para ampliarem sua rede. Mackenzie, procurando aproveitar as oportunidades, agia para obter contratos visando à concessão de energia elétrica, em especial da Empresa Reid que estava prestes a caducar, pois o privilégio de quinze anos havia sido concedido por ato anterior ao Decreto $\mathrm{n}^{\circ} 1001$. Enquanto Mackenzie negociava os contratos no Brasil, Pearson tentava constituir a Companhia no Canadá. ${ }^{25}$

Em 1905, Mackenzie conseguiu a unificação dos contratos de energia elétrica e iniciou uma batalha pela revisão dos contratos atingidos pelo supramencionado decreto, conseguindo, ao final, a prorrogação dos prazos de concessão. O flagrante desrespeito às disposições do Decreto $n^{\circ} 1001$ foram duramente criticadas pela imprensa à época. Em 1907, o empresário canadense conseguiu unificar três grandes companhias de bonde e continuou adquirindo progressivamente outras empresas menores em busca da dominação do mercado., conforme assinala Weid (1994, p.22):

Em 1911, a Light entrou com um mandato judiciário para impedir a construção, alegando privilégio de zona em virtude da aquisição da Companhia Ferro-Carril de Madureira. A luta entre o já então 'polvo canadense' e a pequena empresa de bondes de tração animal durou até 1928, com a transferência da concessão e a eletrificação da última linha da cidade, tirando de circulação o último bonde de burros.

${ }^{25}$ Cf. WEID, 1994, p.24. 
Assim, após vencer a batalha, a Light implementou o bonde elétrico em praticamente toda a cidade do Rio de Janeiro em caráter monopolista, tendo em vista os benefícios de zona e os longos prazos de concessão, exemplo deste foi o prazo concedido para o contrato de unificação das Companhias São Cristóvão, Vila Isabel e Carris Urbanos celebrado em 1905 por Mackenzie que previa o privilégio de zona até 1940 e o prazo de concessão até 1970.(WEID, 1994, p.25)

Em São Paulo também ocorreu processo semelhante. O monopólio da Light foi questionado em 1909 por empresas nacionais, dentre elas figurava o Grupo Guinle. Após uma intensa batalha judicial contra a prefeitura, o monopólio da Light foi confirmado, em contrapartida a empresa canadense foi obrigada a oferecer ações à administração municipal, adotar veículos especiais para operários com desconto e oferecer desconto nas tarifas de energia elétrica. $^{26}$

Elizabeth Weid ressalta que apesar do processo de ampliação da rede pela Light, a estratégia desenvolvida por esta última no tocante à expansão das linhas possibilitou o estabelecimento de um sistema ligando praticamente todas as áreas da cidade do Rio de Janeiro. Neste sentido Weid escreveu:

O resultado dessa estratégia foi um excelente sistema de transporte coletivo urbano e suburbano, aproximando diferentes regiões da cidade, abrindo caminho nas barreiras de montanhas, distribuindo-se pela difícil topografia do Distrito Federal, e abrindo novas áreas de habitação, de comum acordo com a prefeitura. (WEID, 1994, p.30)

Os bondes reinaram no cenário urbano praticamente absolutos até a década de 30 quando, em razão do aumento de custos resultantes da crise de energia provocada pela seca de $1924^{27}$ e das instabilidades políticas, começaram a perder seu espaço.

Em 1924, São Paulo foi cenário do levante tenentista fortemente reprimido pelo presidente Arthur Bernardes que mandou bombardear a cidade. Os ataques causaram graves prejuízos à Light ao destruir quilômetros de linhas de bonde e transmissão elétrica. Os problemas das empresas de bonde se intensificaram no ano de 1925 quando grave seca atingiu

\footnotetext{
26 De acordo com a reportagem conduzida por Ayrton Camargo e Silva, Disponível em < http://www2.uol.com.br/historiaviva/reportagens/a_morte_do_bonde.html > Acesso em 08 de jan. de 2015.

27 Especialmente em São Paulo, a grande seca de 1924 prejudicou o fornecimento de energia o que atingiu negativamente a regularidade do serviço de bondes elétricos. (ANTP, vol. I, 2014, p. 35)
} 
o Estado de São Paulo, prejudicando o fornecimento de energia elétrica e, via de consequência, a regularidade do referido transporte. ${ }^{28}$

Além das instabilidades climáticas e políticas, o prestígio do bonde foi abalado pelo início da montagem de ônibus no Brasil por montadoras estrangeiras que se utilizavam das carrocerias feitas no país sobre chassis de caminhões importados. ${ }^{29}$

A despeito da crescente importância do transporte rodoviário, DUNLOP (1953, p.IX) ressalta que não foi apenas a chegada de meios de transportes mais rápidos que determinou a perda de espaço do bonde como veículo coletivo principal, mas sim o custo elevado do material rodante, o quadro numeroso de funcionários, o aumento periódico de salários, as indenizações vultosas em razão de acidentes e, principalmente, à manutenção de tarifas muito baixas, o que contrastava com os aumentos sucessivos concedidos ao serviço de iluminação privada, o que reduziu os resultados comerciais dos serviços de bondes e, consequentemente, diminuiu os investimentos no modal. ${ }^{30}$

A agonia, no entanto, seria lenta, as últimas linhas regulares de bonde no Rio de Janeiro $^{31}$ e em São Paulo somente seriam fechadas na década de sessenta do século XX.

\footnotetext{
${ }^{28}$ Disponível em < http://www2.uol.com.br/historiaviva/reportagens/a_morte_do bonde.html $>$ Acesso em 08 de jan. de 2015.

${ }^{29}$ (ANTP, Vol. I, 2014, p. 35)

${ }^{30}$ Segundo Ayrton Camargo e Silva, o contrato de concessão de bondes firmado com o Município de São Paulo, por exemplo, não previa reajustes das tarifas em razão da inflação. As tarifas de energia elétrica, por seu turno, sofriam reajustes periódicos, por esse motivo a expansão da rede elétrica passou a representar uma importância maior nos negócios da Light em detrimento do transporte. Disponível em < http://www2.uol.com.br/historiaviva/reportagens/a_morte_do_bonde.html >_Acesso em 08 de jan. de 2015.

${ }^{31}$ A linha de Bonde do bairro de Santa Teresa/RJ, reinaugurada em 2014, embora tenha forte conteúdo turístico e cultural, tem impacto bastante restrito como modal de transporte. "Já foram instalados cerca de 3,5 km de trilhos e rede aérea na região. A subestação de energia e a oficina também passam por reformas. Ainda estão previstas as reativações dos trechos da Rua Francisco Muratori e da Estação Silvestre, que estavam desativados há anos. O traçado anterior era de cerca de $7 \mathrm{~km}$. O atual é de 10,5 km. Após a conclusão das fases de testes, os bondes iniciarão a operação assistida com passageiros (...) Os novos veículos, que tiveram o visual original aprovado pelo Iphan (Instituto do Patrimônio Histórico e Artístico Nacional) e pelo Inepac (Instituto Estadual do Patrimônio Cultural), preservam as características estéticas tradicionais, entre elas a identidade visual, dimensões, cores, conjunto estético e os bancos de madeira." Disponível em $<$ http://odia.ig.com.br/noticia/riode-janeiro/2014-10-26/circulacao-do-bonde-de-santa-teresa-surpreende-turistas-e-cariocas-na-lapa.html

Acesso em 27 de out. de 2014.
} 
1.2. Da Era Vargas até o início da Nova República: a ascensão do rodoviarismo e a urbanização do Brasil

Historicamente a ocupação de um território apresenta estreitas relações com a abertura de vias. Segundo Eichengreen, a expansão da malha ferroviária nos Estados Unidos serviu aos interesses dos comerciantes em estabelecer vias de comunicação e também aos interesses do governo norte-americano em ocupar áreas mais distantes. No Brasil, a contrario sensu, a ocupação ocorreu de forma improvisada, sem planejamento prévio. (ACIOLI, 2007, p.75)

De acordo com Lima Neto (2001, p.421), as concessões dos sistemas de transporte ferroviário durante todo o período imperial brasileiro sofreram grande influência dos proprietários rurais, de modo que as negociações não eram realizadas de forma transparente; ocultando, na maior parte das vezes, privilégios da elite agrária, principalmente dos proprietários rurais com assento nos parlamentos. Como resultado desse processo, as áreas servidas por estradas de ferro ganhavam uma competitividade desigual. Neste sentido, destaca Lima Neto (2001, p.421):

\footnotetext{
Evidentemente, nem se cogitava introduzir um processo competitivo em termos de seleção do investidor que maior vantagens traria para o Poder Público em troca de explorar uma determinada ligação prevista em plano público. Buscar maior eficiência nos serviços não era incentivado, tendo em vista a prática pouco transparente e casuística de subsídios governamentais.
}

Apesar da ausência de critérios transparentes para as concessões de ferrovias e de planejamento viário de longo prazo, desde o império vários esboços de planos de viação foram formulados. Embora nenhum dos planos tenha sido adotado formalmente, merecem destaque o plano elaborado pelo engenheiro João Ramos de Queiroz, apresentado ao Instituto Politécnico Brasileiro em 1874, e o plano do então engenheiro-chefe da Diretoria de Obras, Honório Bicalho, apresentado ao Ministro da Agricultura, Comércio e Obras Públicas, em 1881. (ACIOLI, 2007, p. 79-81).

Em 1882, por ocasião do Primeiro Congresso Ferroviário realizado no Clube de Engenharia do Rio de Janeiro, foi criada uma comissão formada pelos engenheiros Antônio Maria de Oliveira Bulhões, Ferino José de Melo e Jorge Redemaker Grunewald visando à criação de um plano nacional de viação. (ACIOLI, 2007, p. 79-81).

Após a Proclamação da República, o Decreto nº 159, de 15 de janeiro de 1890, criou uma comissão cujo objetivo era organizar um plano de viação férrea e fluvial. Embora não 
tenha sido adotado em sua integralidade, o plano da comissão norteou as principais linhas ferroviárias subsidiadas pelo governo a partir de sua elaboração. Por meio do Decreto $\mathrm{n}^{\mathrm{o}} 524$ de 26 de junho de 1890, foram definidas as competências da União e dos Estados para a concessão de estradas de ferro, segundo as diretrizes do Plano de Viação formulado pela referida comissão (ACIOLI, 2007, p. 82).

No plano constitucional, a primeira Carta brasileira que consignou o dever do Estado de criar um Plano Nacional de Viação (PNV) foi a Constituição de 1934, que manteve a competência privativa da União para explorar ou dar em concessão as vias férreas que ligassem os portos marítimos às fronteiras nacionais ou transpusessem os limites de um Estado.

O Plano Nacional de Viação, aprovado pelo Decreto ${ }^{\circ}$ 24.497, de 29 de junho de $1934^{32}$, continha a descrição das vias de transporte, a relação descritiva dessas vias e as condições de ordem técnica que deveriam ser atendidas na construção das vias de comunicação terrestre e vias férreas nacionais, estabelecia, ainda, que a construção, concessão ou reforma pelos estados ou municípios de qualquer via de transporte em seu território, compreendidas no plano geral de viação nacional, somente poderia ser feita mediante aprovação da União, observadas as normas técnicas constantes no Plano e as determinações do Ministério de Viações e Obras.

A Revolução de 1930, inicialmente, reduziu os incentivos lançados por Washington Luís que reproduziu em âmbito nacional as ideias praticadas quando era governador de São Paulo, no sentido de privilegiar o transporte rodoviário. Apesar das dificuldades políticas e econômicas do período, a partir de 1931 os investimentos no setor rodoviário tornaram-se significativos, fruto da crescente pressão dos rodoviaristas que também conseguiram a criação do Departamento Nacional de Estradas e Rodagem (DNER) com a edição da Lei ${ }^{\circ}$ 467, de 31 de julho de 1937. O referido órgão, contudo, nasceu sem autonomia administrativa e orçamentária. (LIMA NETO, 2001, p.226).

A Constituição Federal outorgada em 10 de novembro de 1937, em seu artigo 15, inciso VII, manteve a competência privativa da União para explorar ou dar em concessão as

\footnotetext{
32 De acordo com Lima Neto (2001, p.215-222), inicialmente o PNV destinava um papel modesto para as rodovias, o que suscitou fortes embates por parte dos rodoviaristas que conseguiram reforma-lo em 1948 . Embora a ampliação do transporte ferroviário estivesse consignada no PNV, a implementação da malha ferroviária, orientada por uma visão de curto prazo, sem preocupação com sua integração reduziu sua competitividade com o transporte rodoviário. Exemplo disso foi o baixo aproveitamento pelo PNV das ferrovias já instaladas, o Plano Nacional de Viação editado em 1934 aproveitou apenas 17.776 km dos $33.173 \mathrm{~km}$ de ferrovias existentes.
} 
vias férreas que ligassem os portos marítimos às fronteiras nacionais ou transpusessem esses limites. As vias férreas e estradas de rodagem poderiam ser exploradas diretamente ou mediante concessão pelos Estados Federados, observado o Plano Nacional de Viação de 1934.

A questão relativa ao estabelecimento de fontes de financiamento destinada especificamente ao transporte rodoviário, todavia, continuava sendo apontada como um entrave pelos rodoviaristas. Em 1939, o VII Congresso Nacional de Estradas de Rodagem escolheu como tema a tributação do transporte rodoviário e a necessidade de destinação de tributos para aplicação exclusiva no setor rodoviário. (LIMA NETO, 2001, p.228)

No tocante ao financiamento das rodovias, Getúlio Vargas editou o Decreto-Lei $\mathrm{n}^{\circ}$ 8.463/1945 que reorganizou o Departamento Nacional de Estradas e Rodagem (DNER) e criou o Fundo Rodoviário Nacional. O apoio concedido por Vargas à expansão do setor rodoviário deveu-se ao reconhecimento da importância que o processo teria para a consolidação de seu programa de fortalecimento da indústria brasileira. (LIMA NETO, 2001, p. 230) Embora Vargas reconhecesse a necessidade de modernizar a rede ferroviária ${ }^{33}$, a diminuição do fluxo de capital nacional e estrangeiro para as ferroviais dificultou a modernização das mesmas, o que foi agravado com o final da II Guerra Mundial. ${ }^{34}$ Este período coincidiu com o aumento da influência dos rodoviaristas e da ampliação do papel do transporte rodoviário no PNV. (LIMA NETO, 2001, p.221-222).

Registre-se que até a década de 30 do século XX, a maior parte do capital estrangeiro estava concentrada nos serviços públicos, sendo que o capital de "risco" investido pela Inglaterra, maior credora do Brasil, era destinado prioritariamente às ferrovias ${ }^{1}$. A partir de 1930, contudo, o fluxo de capital inglês foi severamente reduzido ao mesmo tempo em que o fluxo de capital norte-americano começou a crescer, este se destinava à indústria de transformação e às atividades comerciais. (ABREU, p. 76 in. ABREU, 1990)

Concomitantemente ao aumento de recursos, o transporte rodoviário e o automóvel em particular começaram a ocupar os espaços urbanos e com isso modificar a relação dos cidadãos, sedimentando uma classificação ainda atual, e quase sempre conflituosa, entre

\footnotetext{
${ }^{33}$ Vargas reconhecia a importância do setor rodoviário no processo de consolidação da indústria nacional. Após sua deposição, José Linhares que assumiu o governo por um curto período, entre 29 de outubro de 1945 a 31 de janeiro de 1946, adotou importantes medidas para o setor rodoviário, como a autonomia financeira e administrativa do DNER. (LIMA NETO, 2001, p.222)

${ }^{34}$ De acordo com Lima Neto, (2001, p.222) ao final da II Guerra, o Brasil era credor da Inglaterra, o governo procurou utilizar esse crédito para investir nas ferrovias, mas não logrou êxito, pois a Inglaterra, que representava a um dos maiores mercados ferroviários, havia decretado "congelamento" de sua dívida externa. $\mathrm{O}$ governo tentou reaver a dívida comprando as empresas ferroviárias inglesas, decisão duramente criticada em razão do péssimo estado das mesmas.
} 
pedestres e motoristas A intensificação das viagens realizadas por automóveis impôs a edição do primeiro Código Nacional de Trânsito, por meio do Decreto $\mathrm{n}^{\circ} 2.994$, de 28 de janeiro de 1941, que revogou o Decreto $n^{\circ} 18.323 / 1928$. O novo código procurou organizar não apenas o trânsito das cidades de maneira uniforme em todo o país, como também as estradas de rodagem que serviriam para a integração do território nacional. Determinava, por exemplo, que os sinais sonoros emitidos pelos guardas de trânsito deveriam ser interpretados conforme o número de silvos: um silvo, significava "pare"; dois silvos, "siga", e assim por diante (art. 24). ${ }^{35}$

O art. 36 do Decreto $n^{\circ}$ 2.994, de 28 de janeiro de 1941, considerava como veículos automotores e, portanto, sujeitos a sua disciplina: os automóveis, caminhões, auto-ônibus, motocicletas com ou sem 'side-cars' e similares, tratores, rolos compressores e congêneres e os "bondes elétricos e seus similares". ${ }^{36} \mathrm{O}$ art. 37 do sobredito decreto dividia os veículos nas seguintes categorias: oficiais, corpo diplomático, particulares e de aluguel, este os de "praça ou garage que estejam à disposição do público, mediante remuneração fixada em tabelas, pela autoridade de trânsito.” Os veículos coletivos eram aqueles que, mediante preço prefixado, era utilizado no "comércio" de transporte de pessoas entre pontos determinados (art. 54, parágrafo único).

Em 1950, por meio da edição da Lei $\mathrm{n}^{\circ} 1.102$, foi instituiu oficialmente o Plano SALTE, prevendo investimentos preferencialmente nos setores de alimentação, energia e transporte. Segundo Acioli (2007, p. 92), cerca de 60\% dos recursos viriam do orçamento da União e $40 \%$ de financiamento externo. O referido plano, contudo, não obteve grandes resultados concretos. (VIANA e VILLELA, 2005, p. 27 apud ACIOLI, 2007, p.94).

Embora o rodoviarismo tenha conquistado espaço paulatinamente na Era Vargas (1930-1945), foi sem dúvida a partir do governo de Juscelino Kubitschek (1956-1961) que o automóvel tornou-se a própria tradução do progresso. O Plano de Metas, adotado pelo Governo JK, incentivou a instalação de montadoras de carros no país, principalmente as norte-americanas. Substituindo o Plano Salte, o Plano de Metas que incialmente previa vultosos investimentos no transporte ferroviário, aos poucos aumentou os investimentos no

\footnotetext{
${ }^{35}$ O Decreto n $^{\circ}$ 3.651, de 25 de setembro de 1941 modificou a redação do antigo Código de Trânsito, com poucas alterações substanciais.

${ }^{36} \mathrm{O}$ art. $7^{\circ}$ do Decreto $\mathrm{n}^{\circ} 18.323 / 1928$ indicava as seguintes categorias de veículos: automóveis cujo peso não excedesse $3.500 \mathrm{Kg}$, automóveis que excedessem $3.500 \mathrm{Kg}$ e "motocyclos", com ou sem side-cars.
} 
transporte rodoviário. (ACIOLI, 2007, p.97). O aumento de investimentos no transporte rodoviário coincidiu com a instalação de grandes montadoras no Brasil.

A escolha pelo automóvel incentivou não apenas a instalação da indústria de transformação, mas também a ampliação de estradas e rodovias e, via de consequência, a adoção do transporte individual em detrimento dos coletivos. ${ }^{37} \mathrm{~A}$ instalação da indústria automobilística era parte importante do Plano de Metas, plano quinquenal inspirado nas orientações da Comissão Mista Brasil-Estados Unidos (CMBEU) e da Comissão Econômica para América Latina e Caribe (CEPAL). A intenção era acelerar a industrialização do Brasil por meio da substituição das importações e investimentos externos. O Plano de Metas, assim como o Plano Salte ${ }^{38}$, trazia a previsão de investimentos em energia, transporte, alimentação, educação e nas indústrias de base. (ACIOLI, 2007, p.91)

O plano previa, ainda, a divisão de atribuições: o governo e as estatais se ocupavam da expansão da rede rodoviária visando à interiorização do processo de desenvolvimento e à inciativa privada caberia financiar projetos voltados para a fabricação de equipamentos e insumos, notadamente, da indústria automobilística. (ACIOLI, 2007, p.102)

Conforme crítica formulada por Renê Schoppa (2004, p.67), a implementação dos meios de transporte no Brasil, tanto o ferroviário quanto o rodoviário, pouco se preocupou com o interesse público ou com a necessidade de desenvolvimento regional. Se no século XIX, a implementação das ferrovias foi realizada sem grande planejamento, ao estilo "catacafé", a partir da década de 50 do século XX, o fortalecimento da indústria automobilística coincidiu com a desativação das linhas de bonde e o aumento do uso de ônibus e automóveis.

Deste modo, a matriz de transporte essencialmente pública e movida à eletricidade (trens e bondes), foi substituída por outra que combinava modais público e privado, dependentes, essencialmente, de combustível fóssil, mais poluente (VACONCELLOS et al, 2011, p.4)

A nova matriz de transporte preocupou-se primordialmente com a criação de mercado para aquisição do produto (automóveis), sem maiores preocupações em diversificar a oferta dos meios de transportes públicos e, deste modo, garantir a fruição do direito fundamental de

\footnotetext{
${ }^{37}$ Com a mudança da matriz de transportes "o governo novamente assume o controle de diversas ferrovias, num processo gradual que culmina com a estatização geral do sistema e a criação da RFFSA em 1957.” (ACIOLI, 2007, p.4).

${ }^{38}$ O Plano Salte "começou em 1946 quando o governo do Presidente Dutra, ao extinguir o 'Plano de Obras e Equipamentos' criado em 1943, resolveu reorientar as diretrizes de planejamento do governo. (...) Das fontes de recursos previstas pelo plano estima-se que $60 \%$ viriam do orçamento da União e $40 \%$ do financiamento externo." (ACIOLI, 2007, p. 90-92)
} 
ir e vir à massa dos cidadãos. Além disso, a eliminação dos bondes limitou cada vez mais a prestação do serviço e aumentou a dependência dos ônibus para significativa parcela da população urbana, que crescia a ritmo vertiginoso sem qualquer planejamento por parte dos órgãos públicos.

O crescente processo de concentração de viagens por meio rodoviário no Brasil, que ocorreu ao longo dos últimos cinquenta anos, pode ser observado no Gráfico infracolacionado:

\section{GRÁFICO nº 1 - Distribuições de viagens urbanas na cidade do Rio de Janeiro}

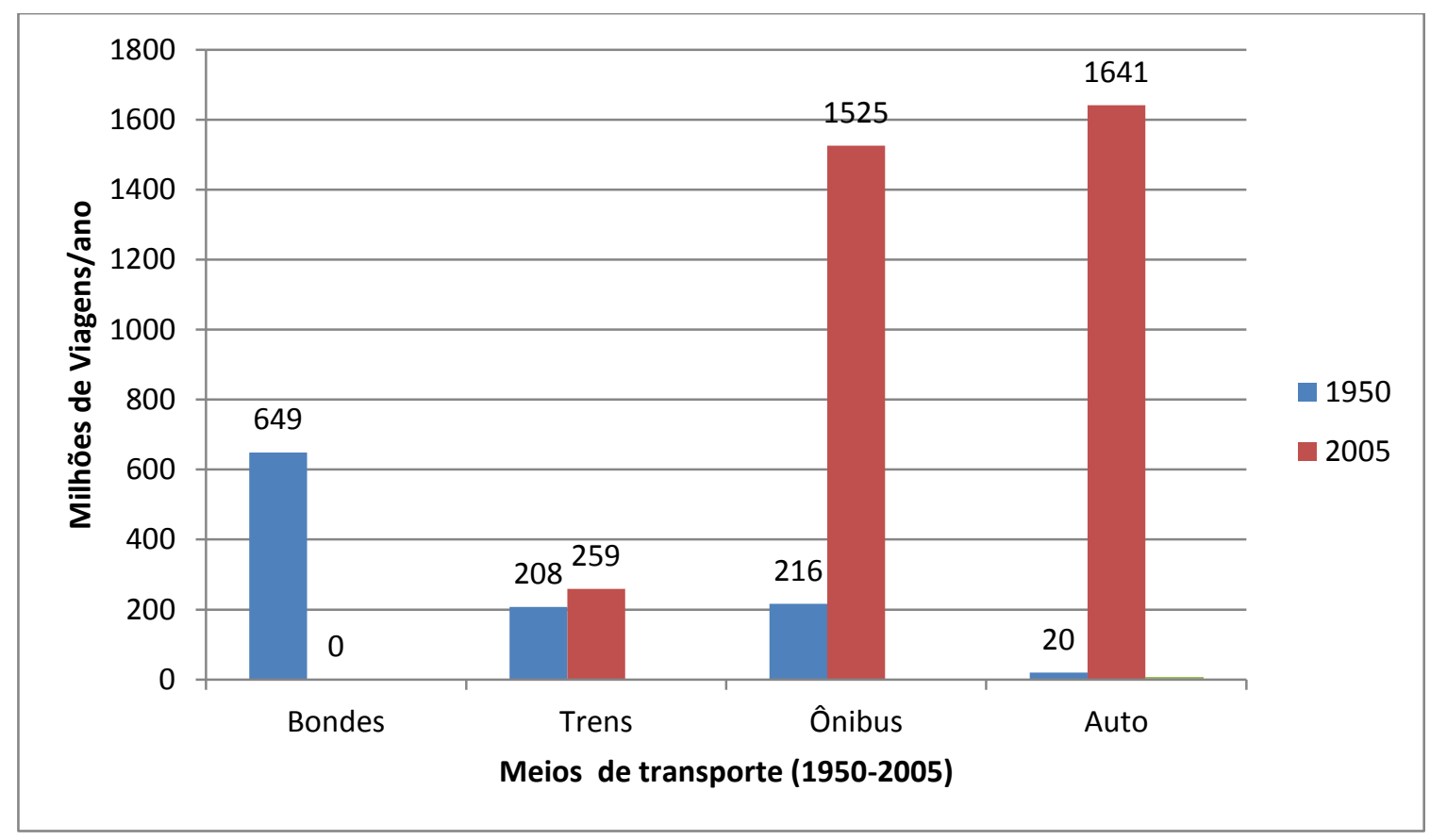

Fontes: Grupo de Estudos de Integração da Política de Transportes (Geiport, 1985) e Associação Nacional de Transporte Público (ANTP, 2005) in. VASCONCELLOS et al, 2011, p. 9

Segundo a Associação Nacional do Transporte Público (ANTP), a decisão de encerrar as linhas de bonde nos anos sessenta representou não apenas a perda de um importante modal de transporte, mas principalmente a mudança no foco da política de transportes, que passou a privilegiar o transporte individual em detrimento do coletivo. Os reflexos dessa mudança são cada vez mais sentidos nos grandes centros urbanos atualmente. (ANTP, parte I, 2012, p.37) 
Importante registrar que adoção do modelo rodoviarista tem sido objeto de críticas ao longo dos anos. Neste sentido, convém transcrever o artigo elaborado por Renê Schoppa ${ }^{39}$ (1982, p.87-89), engenheiro e diretor da Rede Ferroviária Federal Sociedade Anônima (RFFSA), ainda em 1974:

Já tivemos a oportunidade de escrever vários artigos, em que levantamos dúvidas sobre os efeitos da expansão permanente da indústria automobilística. [...]

Sempre perguntamos: - Quanto se está pagando para viabilizar o uso indiscriminado do automóvel?[...]

No momento em que as únicas preocupações parecem ser a procura de fontes alternativas de energia e as novas prospecções de petróleo, há que se meditar sobre a verdadeira função do automóvel, evitando-se que o interesse de uma minoria privilegiada sufoquem a nossa economia. [...]

A respeito da rede de interesses ligada ao setor de transportes, colaciona-se o depoimento de Ermínia Maricato, professora da Faculdade de Arquitetura e Urbanismo da Universidade de São Paulo (USP) e ex-Secretária Executiva do Ministério das Cidades, concedida à Revista Desafios do Desenvolvimento - IPEA: (IPEA, 2011a)

\begin{abstract}
É obvio que o automóvel está no centro da mobilidade. E não só ele, mas toda uma indústria de produção e distribuição de combustível e também uma indústria de produção de infraestrutura urbana a partir da chamada indústria da chamada construção pesada. O automóvel está no núcleo de uma rede de interesses, que estão entre os maiores no mercado capitalista.
\end{abstract}

Segundo Acioli (2007, p.102) a escassez de recursos para reformular e modernizar a malha ferroviária dificultou a sua competitividade com o transporte rodoviário no processo de integração do território. Ainda segundo o referido autor, o imediatismo do mercado, que pressionava pela adoção de medidas com vistas à industrialização, conduziu à mudança definitiva da matriz de transportes.

\footnotetext{
39 Schoppa (1982, p.91), destaca, ainda, que a indústria automobilística foi implementada no Brasil seguindo um modelo econômico importado dos países desenvolvidos, o que conduziu o país a um círculo vicioso, difícil de romper, "pois a indústria automotiva e seus satélites são os grandes empregadores de mão-de-obra urbana. Qualquer redução do ritmo de produção, acarretaria problemas sociais de consequências imprevisíveis.” Schoppa apresenta, em 1974, uma previsão que terminou por se concretizar nas primeiras décadas do século XXI: "[A]lguém chegou a afirmar que o Brasil corre o risco de transformar [...] suas grandes metrópoles em um 'mar' de automóveis , movimentando-se cada vez mais lentamente."
} 
Após o golpe de 1964, os Governos Militares continuaram a financiar a infraestrutura do transporte rodoviário. O primeiro Plano Nacional de Viação do período da Ditadura foi editado por meio do Ato Institucional no 5, de 13 de dezembro de 1968, antes o regime já havia alterado a estrutura do Departamento de Estradas e Rodagens (DNER) por meio do Decreto-lei $\mathrm{n}^{\circ}$ 122, de 31 de janeiro de 1969. Competia ao DNER planejar, projetar, financiar, controlar e supervisionar os serviços de implantação, pavimentação, conservação e restauração das estradas integrantes do PNV, além de exercer a política de trânsito naquelas estradas e a de tráfego interestadual, inclusive no que se refere às concessões dos serviços de transporte coletivo de passageiros (art. $2^{\circ}$ ).

A Lei $n^{\circ} 5.108$, de 21 de setembro de 1966, revogou o Decreto $n^{\circ} 3.651$, de 25 de setembro de 1941 e instituiu o novo Código Nacional de Trânsito que disciplinou a composição da Administração do Trânsito em conselhos e órgãos executivos nas três esferas da federação ${ }^{40}$, definindo a competência de cada uma delas. O Conselho Nacional de Trânsito, órgão normativo e organizador, estava subordinado diretamente ao Ministério da Justiça e Negócios Interiores. As determinações da Lei $n^{0}$ 5.108, de 21 de setembro de 1966 seriam aplicadas às motocicletas, motonetas, motofurgões, tratores, microtratores, cavalos-mecânicos (conjunto formado pela cabine e motor do caminhão), reboques, carretas e similares (art.37, $\S 3^{\circ}$ ). Os bondes, contudo, não foram incluídos no dispositivo.

Em razão da determinação contida no artigo $8^{\circ}$, item XI, da Constituição de 1967, reproduzido pela Emenda Constitucional no 1 de 1969, foi aprovado, por meio da Lei $n^{\circ}$ 5.917, de 10 de setembro de 1973, o novo Plano Nacional de Viação. Em 1975, por intermédio da Lei $\mathrm{n}^{\circ}$ 6.261, de 14 de novembro de 1975, foi instituído o Sistema de Transporte Urbano, que compreenderia o conjunto dos sistemas metropolitanos e sistemas municipais nas demais áreas urbanas vinculadas. O Plano Nacional de Viação tinha por objetivo "essencial" atender "às necessidades do País, sob o múltiplo aspecto econômicosocial-político-militar" (art. $2^{\circ}$ ) em virtude da crescente urbanização da sociedade brasileira.

Deve-se assinalar, ainda, que entre 1960 e 1980 foram criados diversos fundos para financiamento dos programas federais com vistas ao desenvolvimento e à implementação dos sistemas de transporte urbano. Entre os principais fundos nacionais, de acordo com os levantamentos de Francisconi e Souza e Mello (apud VASCONCELLOS et al, 2011, p. 37), destaca-se o Fundo de Desenvolvimento de Programa Integrados (FDPI), instituído pelo

\footnotetext{
${ }^{40}$ O Código de Trânsito previa a divisão entre órgão federal, estaduais e municipais, embora os municípios não fossem considerados pela Constituição de 1941 como entes da federação; status que somente foi adquirido com a promulgação da Constituição Federal de 1988.
} 
Decreto $\mathrm{n}^{\circ}$ 72.026, de 6 de abril de 197, que contava com fontes do Orçamento Geral. O principal objetivo do FDPI era apoiar programas regionais integrados visando à desconcentração da atividade industrial com foco no nordeste; cerca de $24,12 \%$ dos recursos do referido fundo eram destinados à infraestrutura de transporte.

Também objetivando o desenvolvimento do nordeste do país, foi instituído o Fundo de Desenvolvimento Urbano do Nordeste (FDUN), criado dentro do Programa de Apoio à Infraestrutura dos Grandes Centros do Nordeste. O FDUN, administrado pelo Banco do Nordeste do Brasil (BNB) e pelo Ministério do Interior, recebia recursos do Banco Nacional da Habitação (BNH), da Caixa Econômica Federal (CEF), do Financiador de Estudos e Projetos (Finep) e do próprio BNB. Até o final de 1973, os recursos eram destinados à elaboração de projetos e obras de natureza nitidamente urbana, principalmente nas capitais. (VASCONCELLOS et al, p. 37-38)

De acordo com Franscisoni e Souza (apud Vasconcellos et al, 2011, p.38), os recursos originalmente destinados à criação do Sistema de Transporte Urbano nem sempre eram empregados neste objetivo. Os recursos foram empregados na abertura de avenidas e pontes, mas também em açougues, matadores e mesmo na construção do Centro de Convenção de Fortaleza que, como ressalta os sobreditos autores, estava localizado fora do perímetro urbano, não havendo critérios transparentes para a seleção das ações.

Dentre os fundos criados durante o regime militar, também merece destaque o Fundo Nacional de Apoio do Desenvolvimento Urbano (FNDU), criado pela Lei 6.256/1975 com recursos do Orçamento Geral, Operações de Crédito e outras fontes internas e externas, dividido em cinco subcontas com as seguintes finalidades: transporte urbano, distritos industriais, saneamento, centros sociais e outros projetos. Cerca de $75 \%$ dos recursos do fundo eram destinados à subconta de transporte urbano inserida em um fundo específico: o Fundo de Desenvolvimento dos Transportes Urbanos (FDTU), criado pela Lei $\mathrm{n}^{\circ}$ 6.261/1975 e gerenciado pela Empresa Brasileira de Transportes Urbanos (EBTU). ${ }^{41}$

\footnotetext{
${ }^{41}$ De acordo com Vasconcellos et al (2011, p. 39): "Durante 1976, seu primeiro ano de atuação, a EBTU firmou convênios em um total de Cr\$4.288.588.000,00 para implantação de programas de, melhorias nos transportes urbanos. Segundo Mello (1981), o Orçamento Plurianual de Investimentos 1978-1980 previa um volume de recursos da ordem de Cr\$14 bilhões nesse período (valores de 1978). (...)

Conforme afirma Mello (1981), os recursos do FDTU são aplicados em programas, nos quais eles representam de $30 \%$ a $40 \%$ dos investimentos, sendo o restante apresentado como contrapartida por estados e municípios. O autor reconhece, contudo, que já durante as décadas de 1970 e 1980 havia um impasse entre a responsabilidade sobre o setor de transporte urbano e as operações para seu financiamento. Isso porque, embora a maior parcela de responsabilidade pelo desenvolvimento urbano estivesse a cargo dos municípios, este nível de governo era o que menos arrecadava, ficando as cidades impossibilitadas de promover melhorias em suas infraestruturas e sistemas de transporte sem a contribuição de recursos federais (MELLO, 1981, p. 150). Essa parece se uma questão que persiste, e que talvez tenha se acentuado, com a distribuição de competência e a estrutura de
} 
A oferta de recursos federais para financiamento de planos de infraestrutura e sistemas de transporte urbanos tornou-se mais escassa a partir da segunda metade dos anos 80 e início dos 90. Até o início da década de 80, a receita tarifária e os recursos orçamentários oriundos de tributos não vinculados constituíam a principal fonte de financiamento do transporte urbano, segundo estudo de Lima apud Vasconcellos et al (2011, p.40).

A crise fiscal dos anos 90 provocou discussões a respeito de novas fontes de financiamento $^{42}$; sendo que, ao final, a tarifa assumiu o papel principal como fonte de recursos para cobrir despesas de operação e custeio do transporte público urbano. A ausência de indicação de outras fontes de financiamento para o setor de transporte teria conduzido à estagnação dos investimentos ao longo dos anos 90, de acordo com estudos divulgados pelo Ministério das Cidades. (BRASIL apud VASCONCELLOS et al, 2011, p. 40)

A Constituição Federal de 1988, assim como as Cartas anteriores, não estabeleceu nenhuma fonte de recursos vinculada ao investimento de transporte público. Objetivando sanar essa falha, foi promulgada a Emenda Constitucional (EC) $\mathrm{n}^{\circ} 33$, de 11 de dezembro de 2001, que instituiu a Contribuição de Intervenção sobre o Domínio Econômico (CIDE) cujos recursos seriam destinados ao pagamento de subsídios a preços ou transporte de álcool combustível, gás natural e seus derivados de petróleo, ao financiamento de projetos ambientais relacionados com a indústria de petróleo e gás e ao financiamento de programas de infraestrutura de transportes. ${ }^{43}$

Apesar do avanço representado pela promulgação da $\mathrm{EC} \mathrm{n}^{\circ} 31 / 2001$, Vasconcellos et al (2011, p.40) faz dois alertas. Primeiro, os recursos arrecadados com a Cide não são necessariamente investidos no setor de transporte em geral e tampouco no transporte coletivo

arrecadação fiscal entre os entes federados, e que vem se desenhando desde a Constituição Federal de 1988 até os dias de hoje."

${ }^{42}$ De acordo com os dados divulgados pelo Ministério das Cidades (2004, p.9) contidos no estudo de Evolução das Tarifas de Ônibus Urbanos - 1994/2003, a tarifa de ônibus urbana sofreu um crescimento de $300 \%$ neste período, passando de 36 centavos para 1 real e 44 centavos. "Na década de 70, as famílias com rendimento familiar de 1 a 3 salários mínimos tinham 5,8\% do seu orçamento familiar comprometidos com o transporte; no início da década de 80 , o percentual atingiu $12,4 \%$; nos anos 90 , a taxa ultrapassou os $15 \%$.”

${ }^{43} \mathrm{O}$ projeto de Lei $\mathrm{n}^{\mathrm{o}}$ 1687/2007, que tratava da Mobilidade Urbana, previa que a transferência dos recursos federais aos Estados e Municípios para a elaboração do Plano de Mobilidade estaria condicionado à contrapartida dos entes federados com recursos da CIDE. O artigo, contudo, acabou excluído da redação final da Lei $\mathrm{n}^{\circ} 12.587 / 2012$. O artigo 24 do Projeto de Lei $\mathrm{n}^{\circ}$ 1687/2007 determinava o seguinte:

“Art. 24 - A proporção dos recursos do PNAMOB destinado a projetos de infra-estutura para o transporte urbano está condicionada à contrapartida dos entes federados com recursos da Contribuição de Intervenção no Domínio Econômico - CIDE, instituída pela Lei no 10.336, de 19 de dezembro de 2001, em:

I - cinquenta por cento dos recursos aplicados pelos Estados e Distrito Federal nos respectivos projetos; e

II - cem por cento dos recursos aplicados pelos Municípios."

Disponivel em < http://www2.camara.leg.br/proposicoesWeb/fichadetramitacao?idProposicao=361135> Acesso em 10 de jan. de 2015. 
urbano. Segundo, diz respeito à "pulverização" dos recursos, conforme foi reconhecido pelos Ministérios da Fazenda e das Cidades na Portaria Interministerial $n^{\circ} 7 / 2006$, na qual restou consignado que "cerca de $7 \%$ dos recursos totais da CIDE são atribuídos entre os mais de cinco mil municípios brasileiros, contudo sem uma vinculação específica ao transporte coletivo" (apud VASCONCELLOS et al, 2011, p.41)

Acrescente-se a isso o fato de o governo, visando conter a inflação, ter zerado as alíquotas da CIDE por meio do Decreto $\mathrm{n}^{\circ}$ 7.764/2012. De acordo com dados divulgados pela Confederação Nacional do Transporte, em 2007 os recursos arrecadados com a CIDE representaram $86 \%$ de todo os recursos federais empregados na infraestrutura do setor de transporte.

\section{Gráfico no 2: Investimento Público Federal em Infraestrutura de Transporte: Valor Total e Recursos da CIDE*}

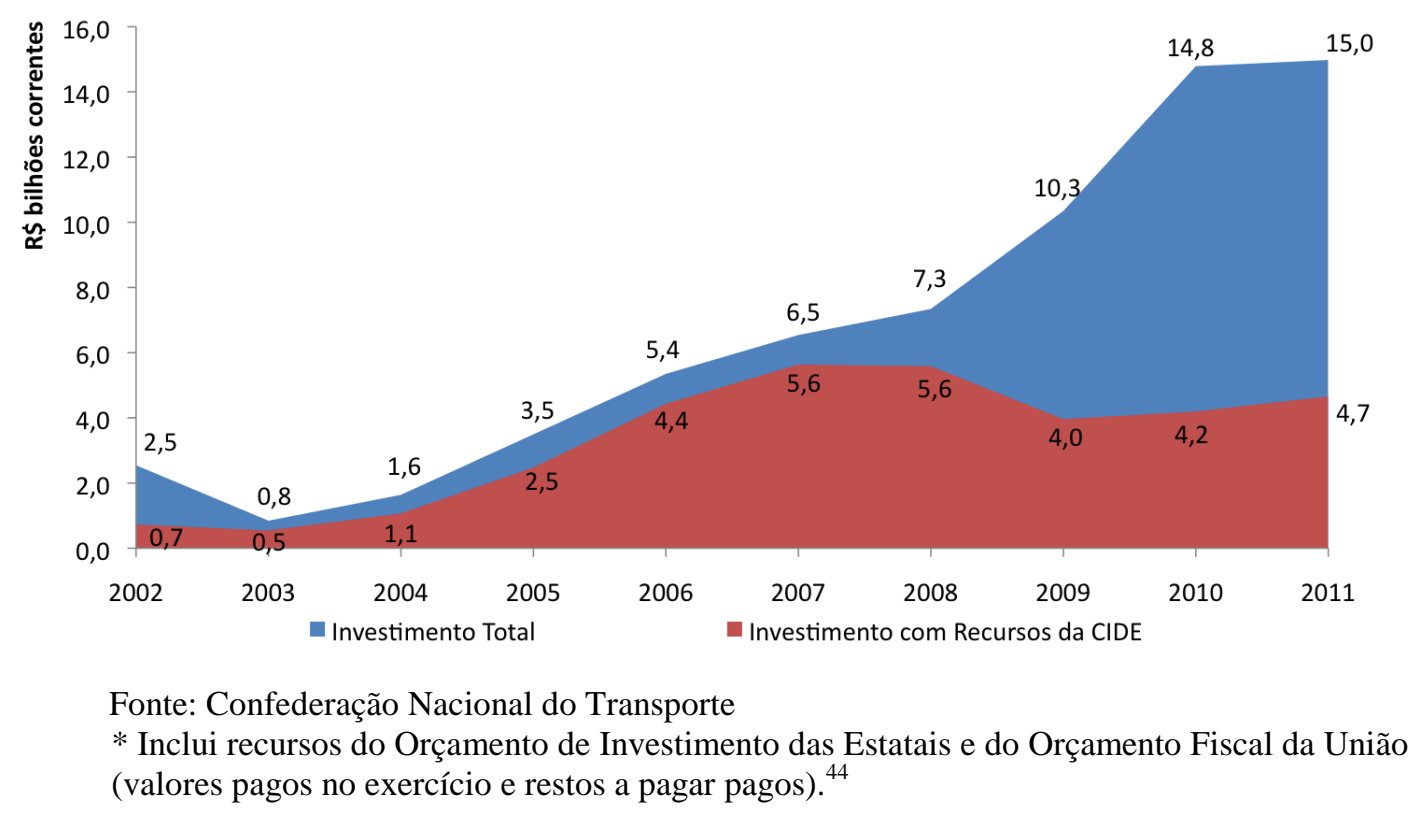

Até aqui foi abordada a legislação pertinente aos transportes públicos, indicando-se o contexto histórico e econômico que ensejaram tais medidas. Verifica-se que a Política de Transporte foi parte importante e, as vezes, fundamental da política econômica brasileira ao longo dos anos. A partir da edição da Constituição Federal de 1988, o foco jurídico se

${ }^{44}$ Disponível em < http://www.cnt.org.br/Paginas/Agencia_Noticia.aspx?n=7852> Acesso em 12 de jan. de 2015. 
transfere do transporte para a mobilidade, ou melhor, para as políticas públicas desenvolvidas com vistas ao exercício do direito fundamental de ir e vir.

1.3. Da mobilidade urbana - mudança de paradigma

A partir da década de 60 , ocorre um rápido crescimento da população urbana nas cidades brasileiras, processo este que se intensificou nos últimos 20 anos, conforme os dados das Séries Históricas e Estatísticas divulgado pelo Instituto Brasileiro de Geografia e Estatística (IBGE). O percentual da população urbana passou de 44, 67\% nos anos 60, para $84,36 \%$ em 2010, conforme se observa na tabela das Séries Históricas colacionada a seguir ${ }^{45}$.

Tabela no 1 - Taxa de urbanização

\begin{tabular}{|l|l|}
\hline 1940 & 31,24 \\
\hline 1950 & 36,16 \\
\hline 1960 & 44,67 \\
\hline 1970 & 55,92 \\
\hline 1980 & 67,59 \\
\hline 2000 & 75,59 \\
\hline 2007 & 81,23 \\
\hline 2010 & 83,48 \\
\hline & 84,36 \\
\hline
\end{tabular}

Fonte: Censo Demográfico Demográfico 1940-2010. Até 1970 dados extraídos de Estatísticas do século XX Rio de Janeiro: IBGE, 2007 o anuário estatístico do Brasil, 1981, vol. 42, 1979.

O deslocamento contínuo da população das áreas rurais e de cidades menores em direção às grandes metrópoles, contudo, não foi acompanhado de um adequado planejamento urbano. Atualmente, as grandes cidades têm uma parcela considerável de sua população

\footnotetext{
${ }^{45}$ Disponível em <http://seriesestatisticas.ibge.gov.br/series.aspx?vcodigo=POP122 $>$ Acesso em 12 de dez. de 2014.
} 
morando em assentamentos irregulares ${ }^{46}$, sem a observância das normas de direito urbanístico. A falta de planejamento trouxe consigo uma série de consequências: além da desordem urbana, também o déficit habitacional, a precária prestação de serviços de saneamento básico e de transporte público.

$\mathrm{O}$ agigantamento das cidades brasileiras fez surgir movimentos a favor de políticas de reforma urbana. Tais movimentos se intensificaram a partir de 1980 com a abertura política. Em 1987, por ocasião da constituinte, foi criado o Movimento Nacional de Reforma Urbana que reuniu movimentos sociais ligados à luta por moradia, transporte e saneamento, além de associações de advogados, engenheiros, arquitetos, sanitaristas, assistentes sociais, entidades acadêmicas, Organizações não-Governamentais, integrantes da Igreja Católica, sindicatos e políticos visando unificar as inciativas em torno de pontos prioritários da política urbana. (MARICATO, p.16 in. SANTOS CARVALHO, 2010) As propostas foram reunidas na Emenda Constitucional de Iniciativa Popular subscrita por 131 mil eleitores. Apesar de não terem sido atendidas todas as sugestões, a Assembleia Constituinte aprovou a inclusão de um capítulo tratando de temas ligados às cidades, além de ter reconhecido a função social da cidade e da propriedade. (Idem) A CRFB de 1988 foi a primeira Constituição Brasileira a consignar em seu texto um capítulo tratando especificamente desses temas.

Além disso, a CFRB de 1988 elevou os municípios à categoria de entes federativos e lhes destinou a competência para executar as políticas de desenvolvimento urbano, conforme diretrizes fixadas em lei. Dispõe o art. 182, caput, da CRFB:

Art. 182. A política de desenvolvimento urbano, executada pelo Poder Público municipal, conforme diretrizes gerais fixadas em lei, tem por objetivo ordenar o pleno desenvolvimento das funções sociais da cidade e garantir o bem- estar de seus habitantes.

De acordo com Edésio Fernandes (in. FERNANDES, 2006, p.7), a inclusão dos artigos 182 e 183 representou uma verdadeira revolução na ordem jurídica brasileira, sendo o reconhecimento de que o país já se encontrava plenamente urbanizado, de modo que e as formas de organização sócio-econômica e político-territorial do Brasil passavam a ser de outra ordem que não aquelas do Código Civil. Contudo, o processo de crescimento das cidades brasileiras ocorreu sob o paradigma jurídico do civilismo clássico, que segundo

\footnotetext{
${ }^{46}$ Os assentamentos irregulares foram definidos pelo art. 47, inciso VI, da Lei $\mathrm{n}^{\mathbf{0}} 11.977 / 2011$ como ocupações inseridas em parcelamentos informais ou irregulares, localizadas em áreas urbanas públicas ou privadas, utilizadas predominantemente para fins de moradia
} 
Edésio Fernandes (2006, p.7), não apresentava respostas às necessidades desse fenômeno complexo que conduziu a transformação de um país agrário-exportador em um país urbanoindustrial.

Aos Municípios também foi atribuída a competência para organizar e prestar diretamente ou sob o regime de permissão e concessão, sempre por meio de licitação ${ }^{47}$, os serviços públicos de interesse local neles incluídos o serviço de transporte (arts. 30, inciso V, c/c art. 175, caput, da CRFB 88). ${ }^{48}$ Não obstante a competência conferida aos municípios para organizar os serviços de transporte em âmbito local, a União preservou sua competência privativa para legislar sobre transporte e trânsito, conforme disposto no art. 20, inciso IX, da CRFB.

Após a promulgação da CRFB de 1988, a despeito das conquistas representadas pela inclusão de dispositivo prevendo a necessidade de estabelecimento de uma política de desenvolvimento urbano, nele incluída a prestação de serviços de transporte, a regulamentação da matéria demorou vários anos. ${ }^{49}$

Em 1995, foi editada a Lei $n^{\circ} 8.987$ que tratou do regime de concessão e permissão da prestação do serviço público, conforme previsto no artigo 175 da CRFB. A referida lei

\footnotetext{
${ }^{47}$ A obrigatoriedade de realização de procedimento licitatório para a prestação de serviços de transporte coletivo municipal foi questão suscitada logo após a promulgação da CRFB 88. As associações de transportadoras sustentavam que o artigo 30 não trazia previsão expressa da referida obrigatoriedade, presente no art. 175. A jurisprudência do Supremo Tribunal Federal "se firmou no sentido da impossibilidade de prestação de serviços de transporte de passageiros a título precário, sem a observância do procedimento licitatório. Nesse sentido foram as decisões proferidas nos Recursos Extraordinários 140.989/RJ, rel. Min. Otavio Gallotti, Segunda Turma, DJ 27.8.1993; 212.357/SP, rel. Min. Carlos Barroso, DJ 15.6.2004; e 264.621/CE, rel. Min Joaquim Barbosa, $2^{\mathrm{a}}$ Turma, DJ $1^{\mathrm{o}} .02 .2005$, no qual, em voto vista, destaquei: 'Com efeito, a exigência de que a prestação de serviços públicos mediante concessão ou permissão seja sempre precedida de licitação (art. 175 da CF), visa propiciar à Administração a possibilidade de selecionar a proposta mais vantajosa sem com isso descuidar dos princípios basilares da isonomia e da moralidade administrativa.' "' (STA AG 89 AG. REG. - Suspensão de Tutela antecipada). Disponível em http://redir.stf.jus.br/paginadorpub/paginador.jsp?docTP=AC\&docID=509461 > Acesso em 15 de jun. de 2015.
}

\footnotetext{
${ }^{48}$ Interessante ressaltar que de todos os serviços públicos apenas para o de transporte "coletivo" a CRFB utilizou a expressão serviço público de caráter "essencial” (art. 30, inciso V, da CRFB), a prestação de serviço de saúde, por outro lado, foi classificado como de "relevância pública" (art. $197 \mathrm{CF}$ ).

A respeito do regime público, aqui entendido como o "conjunto de regras integradas para consecução de uma finalidade comum", ARANHA (2013, p.48-49) destaca que "[p]róxima às atividades exclusivas encontram-se as atividades privativas do Estado. Elas são de titularidade estatal, mas a própria constituição permite a transferência de sua prestação aos particulares por intermédio de contratos administrativos de concessão ou de permissão (art. 175 da Constituição Federal de 1988), o Estado continua responsável subsidiariamente por sua prestação.

Dentre as atividades privativas, encontram-se a parcela de serviços regulados essenciais à sociedade em seu conjunto e que abrangem, a depender do autor, todos ou parcela dos serviços de telecomunicações, energia elétrica, mineração, transportes, dentre outros.” (grifos do autor)

${ }^{49}$ De acordo com Edésio Fernandes (in. FERNANDES, 2006, p.7) os dez anos que se seguiram a promulgação da Constituição foram marcados por uma intensa discussão e negociação no Congresso Nacional a respeito da regulamentação do Capítulo II da CRFB que trata da Política Urbana até a aprovação do Estatuto da Cidade.
} 
disciplinou as condições dos contratos, a política tarifária, os direitos e obrigações dos usuários, as regras de licitação e os encargos do poder concedente. Em seu art. $6^{\circ}$, a lei $\mathrm{n}^{\circ}$ 8987/95 definiu serviço público adequado como sendo aquele que satisfaz as condições de regularidade, eficiência, segurança, atualidade, generalidade, cortesia na sua prestação e modicidade das tarifas. A atualidade compreenderia a modernidade das técnicas, dos equipamentos e das instalações, além da melhoria e expansão do serviço.

Pouco tempo depois foi editada a Lei $n^{\circ}$ 9.503/97 que revogou a Lei $n^{\circ} 5.108$, de 21 de setembro de 1966, e instituiu o novo Código de Trânsito Brasileiro (CTB). De acordo com o novo CTB, o Sistema Nacional de Trânsito (SNT) é formado por órgãos executivos das três esferas da federação. Dentre os objetivos básicos do SNT, consoante disposto no art. $6^{\circ}$, inciso I, ressalta-se o estabelecimento de diretrizes da Política Nacional de Trânsito visando à segurança e à fluidez do trânsito.

Aprovada em 2000, a Lei $n^{\circ} 10.098$ estabeleceu as normas gerais ${ }^{50}$ e critérios para a promoção da acessibilidade de pessoas com deficiência e com mobilidade reduzida, além de consignar regras de mobilidade urbana, antes mesmo do marco regulatório, posto que estipulou critérios para o desenho e o mobiliário urbano ${ }^{51}$.

Em atenção às disposições contidas no art. 178 da CRFB que determinava a edição de lei ordenando o transporte aéreo, aquático e terrestre, foi editada a Lei n ${ }^{\circ} 10.233$ de 5 de junho de 2001, que criou a Agência Nacional de Transportes Terrestres (ANTT), a Agência Nacional de Transportes Aquaviários (ANTAQ), o Departamento Nacional de Infra-estrutura de Transportes (DNIT) ${ }^{52}$ e o Conselho Nacional de Integração de Políticas de Transporte, todos vinculados ao Ministério dos Transportes.

A supramencionada lei dispõe que a ANTT terá competência para atuar no transporte ferroviário de passageiros e cargas ao longo do Sistema Nacional de Viação, a exploração de

\footnotetext{
50 Em 2009, a lei no 11.982 determinou a adaptação de, no mínimo, 5\% dos brinquedos e equipamentos dos parques de diversões, públicos e privados, para atender as necessidades das pessoas com deficiência ou com mobilidade reduzida.

${ }^{51}$ De acordo com o art. $2^{\circ}$, inciso I, da Lei $\mathrm{n}^{\circ}$ 10.098/2000, o mobiliário urbano é "o conjunto de objetos existentes nas vias e espaços públicos, superpostos ou adicionados aos elementos da urbanização ou da edificação, de forma que sua modificação ou traslado não provoque alterações substanciais nestes elementos, tais como semáforos, postes de sinalização e similares, cabines telefônicas, fontes públicas, lixeiras, toldos, marquises, quiosques e quaisquer outros de natureza análoga"

52 O Departamento Nacional de Infraestrutura de Transportes (DNIT), autarquia federal vinculada ao Ministério dos Transportes, assumiu parte das atribuições do antigo Departamento Nacional de Estradas de Rodagem (DNER). Disponível em < http://www.dnit.gov.br/acesso-a-informacao/insitucional $>$ Acesso em 12 de dez de 2014.
} 
infraestrutura ferroviária e o arrendamento dos ativos operacionais correspondentes, o transporte rodoviário interestadual e internacional de passageiros, transporte rodoviário de cargas, exploração da infraestrutura rodoviária federal, transporte multimodal, transporte de cargas especiais e perigosas e ferrovias; devendo se articular com os órgãos e instituições dos Estados, do Distrito Federal e dos Municípios para o uso da via permanente sob sua jurisdição com as redes locais de metrô e trens urbanos destinados ao deslocamento de passageiros.

Decorridos mais de dez anos da promulgação da Constituição Federal, foi editado o Estatuto da Cidade, Lei $\mathrm{n}^{\mathrm{o}}$ 10.257, de 10 de julho de 2001, prevendo o direito à cidade sustentável, nele compreendido os direitos à moradia, ao saneamento ambiental, à infraestrutura urbana, ao transporte e aos demais serviços públicos ${ }^{53}$. A oferta de equipamentos urbanos e comunitários, transportes e dos serviços públicos deveriam ser adequados aos interesses e necessidades da população e às características locais.

A Medida Provisória no 2220 de 4 de setembro de 2001 criou o Conselho Nacional do Desenvolvimento Urbano órgão deliberativo e consultivo vinculado à Presidência da República. Posteriormente, o conselho foi denominado Conselho das Cidades (ConCidades) pelo Decreto $\mathrm{n}^{\mathrm{o}} 5.031$, de 2 de abril de $2004^{54}$, e passou a ser vinculado ao Ministério das Cidades.

O Estatuto das Cidades determinou a elaboração do Plano Diretor para cidades com mais de 20 mil habitantes. Apesar da elaboração do Plano Diretor ser obrigatória, sujeitando os prefeitos que não o providenciarem às penas da Lei de Improbidade Administrativa, até 2008, de acordo com dados do Ministério das Cidades, ${ }^{55} 1700$ municípios com mais de vinte mil habitantes ainda não tinham Plano Diretor.

No tocante à Mobilidade Urbana especificamente, o Estatuto da Cidade consignou dois instrumentos que auxiliam no planejamento sob esse aspecto, são eles o Estudo de Impacto de Vizinhança (EIV) e o Plano de Transporte Urbano Integrado.

\footnotetext{
${ }^{53}$ De acordo com Edésio Fernandes (in. FERNANDES, 2006, p.7), "o Brasil tem ganhado prêmios internacionais pelo simples fato de ter aprovado o Estatuto da cidade. Hoje, o desafio a ser enfrentado é o de materializar essa ordem jurídica criada pela Constituição de 1988 e consolidada pelo Estatuto da cidade e pela Medida Provisória 2.220/2001."

${ }^{54}$ Revogado pelo Decreto ${ }^{\circ}$ 5.790, de 25 de maio de 2006.

${ }^{55}$ Dados da "Campanha Plano Diretor" desenvolvida pela Secretaria Nacional e Acessibilidade e Programas Urbanos. Disponível em < http://www.cidades.gov.br/index.php/planejamento-urbano/350-campanha-planodiretor.html > Acesso em 13 de dez. de 2014.
} 
O Plano de Transporte Urbano Integrado, segundo o Estatuto das Cidades, deveria ser elaborado pelas cidades com mais de quinhentos mil ${ }^{56}$ habitantes de forma integrada ao Plano Diretor. O Ministério das Cidades, em virtude das disposições contidas na Resolução ${ }^{\circ}{ }^{34}$, de 01 de julho de 2005, do Conselho das Cidades, adotou a denominação Plano Diretor de Transporte e da Mobilidade Urbana (BRASIL, 2007, p. 33).

De acordo com a sobredita Resolução, o Plano Diretor de Transporte e da Mobilidade Urbana (PlanMob) deveria garantir a diversidade da modalidade de transportes, respeitando as características das cidades e privilegiando o transporte coletivo. O Plano de Mobilidade Urbana deveria também prever a atuação do poder publico em prol da diminuição da necessidade de viagens motorizadas por meio da descentralização de serviços públicos e pela aproximação das oportunidades de trabalho e moradia. (BRASIL, 2007, p.34)

Ainda de acordo com o Ministério das Cidades, o PlanMob, se diferencia dos planos de transportes tradicionais, principalmente os desenvolvidos na década de 70 , porque esses se limitavam a consignar propostas de intervenções na infraestrutura e na organização espacial dos serviços, ignorando a dimensão estratégica da gestão da mobilidade que inclui os aspectos de financiamento, "conflitos resultantes da apropriação dos espaços públicos ou de mercado e a própria realidade social". (BRASIL, 2007, p.34).

Além do Plano Nacional de Transporte Urbano, o art. 36 do Estatuto da Cidade estabeleceu que lei municipal definirá os empreendimentos e atividades privadas ou públicas cuja concessão de licenças ou autorização estariam condicionadas à elaboração de estudo prévio de impacto de vizinhança (EIV). O EIV, que não substitui a elaboração e aprovação de estudo prévio de impacto ambiental (EIA), deve abordar o adensamento populacional, equipamentos urbanos e comunitários, o uso e ocupação do solo, a ventilação e iluminação, paisagem urbana, a valorização imobiliária e a geração de tráfego e demanda por transporte público.

Apesar de ser um dos mais importantes instrumentos de planejamento da mobilidade urbana, o estudo de impacto de vizinhança, especialmente como condicionante para a instalação de Polos Geradores de Tráfego (PGT). ${ }^{57}$, não tem sido implementado com a agilidade pertinente à matéria. O Distrito Federal, por exemplo, somente em 05 de agosto de

\footnotetext{
${ }^{56}$ A lei $\mathrm{n}^{\circ} 12.587 / 2012$, que instituiu a Política Nacional de Mobilidade Urbana determinou que o plano deverá ser elaborado por cidades com mais de 20.000 (vinte mil) habitantes

57 "Os polos geradores de tráfego são empreendimentos de grande porte que atraem ou produzem grande número de viagens, causando reflexos negativos na circulação viária em seu entorno imediato e, em certos casos, prejudicando a acessibilidade de toda a região, além de agravar as condições de segurança de veículos e pedestres." (DENATRAN, 2001, p. 6)
} 
$2014^{58}$ editou o Decreto $\mathrm{n}^{\mathrm{o}} 35.706$ que regulamentou a Lei $\mathrm{n}^{\mathrm{o}} 5.022 / 2013$, que trata dos aspectos relacionados ao Estudo de Impacto de Vizinhança.

Em atenção às demandas por políticas públicas de desenvolvimento urbano, especialmente aquelas relativas à prestação de serviços de transporte e mobilidade, foi criado pela Lei $\mathrm{n}^{\mathrm{o}}$ 10.683, de 28 de maio de 2003, o Ministério das Cidades, em cuja estrutura encontram-se a Secretaria Nacional de Transporte e da Mobilidade Urbana (SNTU), a Secretaria Nacional de Habitação (SNH), a Secretaria Nacional e Saneamento Ambiental (SNSA), a Secretaria Nacional de Acessibilidade e Programas Urbanos (SNAPU) e o Departamento Nacional de Trânsito (DENATRAN), órgão máximo executivo de trânsito, até então vinculado ao Ministério da Justiça.

O Ministério das Cidades, por meio de suas Secretarias, tem desenvolvido programas objetivando o financiamento de projetos e obras de mobilidade urbana e acessibilidade, além da qualificação técnica de órgãos estaduais e municipais. ${ }^{59}$

A criação do Ministério por meio da Lei $n^{\circ} 10.683 / 2003$ precedeu, portanto, a edição da Lei ${ }^{\circ}$ 12.587, de 3 de janeiro de $2012^{60}$, que instituiu a Política Nacional de Mobilidade Urbana (PNMU). A mobilidade urbana foi timidamente definida pela Lei $\mathrm{n}^{\mathrm{o}} 12.587 / 2012$ como sendo a "condição em que se realizam os deslocamentos de pessoas e cargas no espaço urbano". O conceito formulado pelo Ministério das Cidades, antes da edição da retromencionada lei (Lei $\left.{ }^{\circ} 12.587 / 2012\right)$ que instituiu a política nacional do setor, revela-se mais detalhado, conforme se verifica a seguir:

\begin{abstract}
O novo conceito (mobilidade urbana) é em si uma novidade, um avanço na maneira tradicional de tratar, isoladamente, trânsito, o planejamento e a regulação do transporte coletivo, a logística de distribuição das mercadorias, a construção da infraestrutura viária, das calçadas e assim por diante. Em seu lugar, deve-se adotar uma visão sistêmica sobre toda a movimentação de bens e de pessoas, envolvendo todos os modos e todos os elementos que produzem as necessidades destes deslocamentos. (BRASIL, 2007, p.21)
\end{abstract}

\footnotetext{
${ }^{58}$ Decreto $\mathrm{n}^{\mathrm{o}}$ 35.706, de 05 de agosto de 2014 publicado no Diário Oficial do Distrito Federal em 06 de agosto de 2014.

${ }^{59}$ De acordo com o sítio eletrônico do Ministério das Cidades, o Programa de Mobilidade Urbana "prioriza a implementação de sistemas de transportes coletivos, dos meios não motorizados (pedestres e ciclistas), da integração entre as diversas modalidades de transportes, bem como a implementação do conceito de acessibilidade universal para garantir a mobilidade de idosos, pessoas com deficiência ou restrição de mobilidade." Disponível em < http://www.cidades.gov.br/index.php/progsemob/211-progmoburb.html > Acesso em 15 de jan. de 2015 .

60 O Projeto de Lei n ${ }^{\circ}$ 694/95, de autoria do Deputado Federal Alberto Goldman, previa a instituição das Diretrizes Nacionais do Transporte Coletivo Urbano. Posteriormente, foi apresentado, pelo Poder Executivo, o Projeto de Lei n 1687/2007 que tratava da Politica Nacional de Mobilidade Urbana.
} 
O conceito de mobilidade, portanto, vai além da prestação de serviço de transporte, posto que, em muitos casos, o transporte inadequado será o principal obstáculo para o exercício do direito constitucional de ir e vir. De acordo com a Lei $\mathrm{n}^{\circ} 12.587 / 12$, a política de mobilidade também deve considerar o zoneamento das cidades e a distribuição de atividades econômicas de forma acessível ${ }^{61}$ e sustentável.

É preciso assinalar, ainda, que a Lei $\mathrm{n}^{\circ} 12.587$, de 3 de janeiro de 2012, instituiu as diretrizes da Política Nacional de Mobilidade Urbana, fundada nos princípios da acessibilidade universal, do desenvolvimento sustentável das cidades, da equidade no acesso dos cidadãos ao transporte público coletivo, da segurança no deslocamento das pessoas, da justa distribuição dos benefícios e ônus decorrentes do uso dos diferentes modos e serviços, da equidade no uso do espaço público e da eficiência, eficácia e efetividade na circulação urbana na prestação de serviços de transportes.

A respeito das inovações trazidas pela Lei $\mathrm{n}^{\circ}$ 12.587/12 convém registrar a definição de atribuições entre os entes federativos no tocante à prestação do serviço de transporte e a estipulação da necessidade de elaboração de Plano de Mobilidade Urbana para os municípios com mais de 20.000 (vinte mil) habitantes integrado com o Plano Diretor (art. 24, § $1^{\circ}$ ).

A título de exemplo da divisão de atribuições previstas na Lei de Mobilidade Urbana, merece destaque a definição da competência da União em fomentar a implantação de projetos de transporte público coletivo de grande e média capacidade nas aglomerações urbanas e nas regiões administrativas (art.16, inciso IV) tal medida se deve ao elevado vulto dos recursos empregados na instalação de modais de grande capacidade. ${ }^{62}$

Além do fomento na implantação de projetos de modais de média e grande capacidade, a Lei no 12.587/2012 atribuiu à União a obrigação de organizar e disponibilizar informações sobre o Sistema Nacional de Mobilidade Urbana e a qualidade e produtividade dos serviços de transporte público coletivo (art. 16, inciso III).

Insta ressaltar que ausência de um sistema com dados nacionais já havia suscitado questionamentos pelo Tribunal de Contas da União (TCU) que, por meio do Acórdão $\mathrm{n}^{\circ}$ 1373/2011 (publicado antes da edição da Lei n 12.587/2012), recomendou a criação de um sistema contendo os referidos dados em virtude dos reflexos provocados pela política de

\footnotetext{
${ }^{61}$ A Lei 12587/2012 define o conceito de acessibilidade como sendo a "facilidade disponibilizada às pessoas que possibilite a todos autonomia nos deslocamentos desejados, respeitando-se a legislação em vigor.”

${ }^{62}$ Neste caso estaria incluído o metrô cuja construção demanda elevados investimentos, além de alto custo de operação e manutenção o que inviabiliza a sua instalação na maioria dos municípios brasileiros mesmo aqueles que apresentem demanda que justifique a adoção deste modal. (BRASIL, 2007, p.93)
} 
mobilidade urbana no desenvolvimento urbano, na inclusão social e na sustentabilidade ambiental. Neste ponto, convém transcrever parcialmente o referido Acórdão:

\begin{abstract}
[...] Em documento publicado no site do Ministério das Cidades, que apresenta as bases da Política Nacional de Desenvolvimento Urbano estabelecem-se três campos estratégicos de ação para a mobilidade urbana: i) desenvolvimento urbano, ii) sustentabilidade ambiental; iii) inclusão social. [...] Recomendações: Ante o exposto neste capítulo, entende-se necessário recomendar à SeMOB, tendo em vista as competências definidas no art. $1^{\mathrm{a}}$ do Regimento Interno, aprovado pela Portaria $\mathrm{n}^{\circ}$ 227/2003 do Ministério das Cidades, que: a) Defina e implemente uma sistemática de coleta e tratamento de informações que permita identificar os problemas, as necessidades e as possíveis soluções ligadas à mobilidade urbana de cidades de porte médio, capitais, aglomerados urbanos e regiões metropolitanas, de modo a dispor de um diagnóstico que reflita com razoável precisão a realidade específica em cada uma dessas localidades e que possa, por extensão, fornecer aos vários setores envolvidos subsídios para o aperfeiçoamento do planejamento e gestão das intervenções nessa área. (Acórdão 1373 - Plenário) ${ }^{63}$
\end{abstract}

A despeito da recomendação do TCU e da disposição contida na Lei no 11.587/2012, o Sistema Nacional de Mobilidade Urbana ainda não foi implementado, estando atualmente em fase de elaboração e coleta de informações pela Secretaria Nacional de Mobilidade Urbana. ${ }^{64}$

De todo modo, insta ressaltar que o conceito de mobilidade urbana, que vem sendo construído nas últimas décadas, tem com foco o estabelecimento de articulações entre as políticas de transporte e a política de desenvolvimento urbano, isto porque a ocupação desordenada e irracional do solo urbano fez surgir áreas totalmente desabitadas, enquanto outras, em geral mais distantes dos grandes centros econômicos, apresentem grande adensamento populacional. O resultado é a crescente demanda por transporte público motorizado como se esta fosse a única solução para a melhoria da mobilidade da população, sem que outras medidas, tais como a melhor distribuição dos serviços públicos ou mesmo a implementação de incentivos ao desenvolvimento de novos centros econômicos, sejam consideradas na formulação das políticas públicas. Essas, na maior parte das vezes, se limitam a tratar da instalação de infraestrutura de transportes. (MINISTÉRIO DAS CIDADES, 2004, p.7-11).

63 $<$ http://portal2.tcu.gov.br/portal/page/portal/TCU/imprensa/noticias/noticias_arquivos/TC\%20018\%20005_2010 -1.pdf $>$ Acesso em 15 dez de 2014.

64 Disponível <http://www.transportes.unb.br/downloads/eventos/politica nacional de mobilidade urbana.pdf $>$ Acesso em 13 de jan. de 2015 


\subsection{Conclusão Parcial}

Conforme visto, a política de transporte no país buscava inicialmente atender ao setor agrário voltado, principalmente, para a exportação do café. Em um segundo momento, a política econômica utilizou-se do setor de transporte como instrumento do processo de industrialização tardia. Em ambos os casos, a preocupação com a integração do território nacional e com a mobilidade dos cidadãos foi relegada a um segundo plano. A política de transporte urbano, em si mesma, resultou da progressiva substituição dos modais públicos movidos por eletricidade (bondes), por modais que utilizam combustível fóssil, primeiro públicos e , ultimamente, privados, com grande concentração de viagens feitas por estes. $\mathrm{O}$ conceito de mobilidade urbana representou, portanto, uma ruptura da política centrada unicamente na implementação de modais de transporte, transferindo o foco daí para políticas públicas cujo objetivo maior é garantir o exercício do direito constitucional de ir e vir.

Nunca é demais ressaltar que o conceito de mobilidade urbana vai além da implementação de "meios de transportes", prevendo também a adoção de medidas pelo Poder Público que visem a descentralização de serviços, o incentivo a atividades econômicas em áreas periféricas com vistas a diminuir a dependência econômica das áreas centrais (e com isso a necessidade de viagens), o incentivo à adoção de meios de transporte não motorizados, etc.

O histórico da política de transporte e da mobilidade urbana oferecido neste capítulo teve como objetivo situar o leitor a respeito da evolução da estruturação das políticas públicas que subjazem a fruição do direito fundamental de ir e vir. Além do mais, a descrição das normas teve o propósito de possibilitar o estabelecimento de relações entre o que tais normas dispõem e o contexto no qual foram criadas, de modo a evidenciar as relações econômicas que permearam as políticas relevantes.

Como será visto adiante (Capítulo 2), as abordagens da dogmática jurídica constitucional e do neoconstitucionalismo constroem seus referenciais analíticos de modo fundamentalmente "formalista", ignorando, muitas vezes, a estrutura das políticas públicas relevantes e seus reflexos econômicos. Por isso, permanecem incapazes de contribuir efetivamente e de maneira tecnicamente útil para a reforma de tal estrutura.

Tendo em vista os propósitos que acabam de ser mencionados, o capítulo 2 apresentará uma breve análise da decisão proferida na Ação Direta de Inconstitucionalidade $n^{\circ}$ 3.768-4 que trata de uma política pública voltada para a fruição do direito de ir e vir, no caso o direito 
à gratuidade do transporte público urbano para pessoas maiores de 65 anos. Por meio da análise deste caso, serão abordados, de forma crítica, os referenciais teóricos da dogmática jurídica e do neoconstitucionalismo cujos discursos afastam o debate a respeito dos aspectos econômicos das políticas públicas.

No capítulo 3, será abordada a importância de se considerar os aspectos econômicos no discurso jurídico. Este tema será desdobrado, por um lado, no exame do tratamento dispensado pela Análise Econômica do Direito às relações entre direito e questões econômicas; e, por outro lado, numa exposição de contribuições da Análise Jurídica da Política Econômica enquanto abordagem jurídica de aspectos econômicos de políticas públicas. Na sequência, a metodologia da AJPE será utilizada na análise da Política de Mobilidade Urbana das Regiões Administrativas de Vicente Pires e Águas Claras, localizadas no Distrito Federal. 


\section{AS LIMITAÇÕES DO DISCURSO JURIDICO PREDOMINANTE NO BRASIL ACERCA DOS ASPECTOS POLÍTICO-ECONÔMICOS DA GRATUIDADE DO TRANSPORTE PÚBLICO}

\section{1 - Observações gerais}

Conforme já destacado, neste capítulo será apresentada a análise dos fundamentos da decisão proferida pelo Supremo Tribunal Federal (STF) no julgamento da Ação Direta de Inconstitucionalidade $(\mathrm{ADI}) \mathrm{n}^{\mathrm{o}}$ 3.768-4, que tratou do direito à gratuidade do transporte público para pessoas maiores de 65 anos. Como se verá adiante, os votos da maioria dos ministros repousam sobre referenciais analíticos da dogmática jurídica e do neoconstitucionalismo, sem que a análise dos aspectos econômicos tenha sido aprofundada no debate.

A escolha deste caso tem por objetivo demonstrar ao leitor de que modo o discurso jurídico predominante no Brasil, fundado nos referenciais da dogmática e do neoconstitucionalismo, ao se esquivar do debate a respeito dos aspectos políticos e econômicos envolvidos na fruição de um direito, no caso o direito à gratuidade do transporte público, fragiliza o seu papel como instrumento de transformação da realidade social.

Registre-se, desde já, que não se tem a pretensão de esgotar a análise dos referenciais analíticos da dogmática ou do neoconstitucionalismo, mas tão somente evidenciar o quanto, apesar da alegada contraposição entre eles, as consequências, no caso concreto, podem revelar as semelhanças entre os discursos.

De acordo com Max Weber (2005, p. 311), a dogmática tem por objetivo identificar o significado das posições cujo conteúdo constitui uma ordem para determinado grupo social, ou seja, define os fatos para o quais se aplicam as normas. Ao jurista compete examinar a norma considerada válida e aplicá-la observando um sistema lógico, livre de contradições internas. Neste processo, conforme ressalta o referido autor, o jurista aceita a premissa de que os fatos aos quais se referem as normas formais são válidos.

Deste modo, o mundo das "formas" jurídicas permanece alheio aos múltiplos aspectos do mundo da economia; servindo para ocultar interesses econômicos e políticos sob o manto da dogmática jurídica que se preocupa em identificar o que é "juridicamente" relevante, 
enquanto propaga ideologias pertencentes a determinados grupos sociais, ao mesmo tempo em que serve para escondê-las sob o manto de aparente neutralidade. ${ }^{65}$

O tratamento dogmático das questões jurídicas é uma característica marcante do direito europeu continental. Segundo Wieacker, trata-se de uma tendência discernível desde o trabalho de juristas medievais. ${ }^{66}$ A partir do século XIX, com o aparecimento das obras de Friedrich von Gerber e Paul Laband, o formalismo dogmático derivado da chamada jurisprudência dos conceitos adquire uma influência decisiva sobre o direito constitucional que se desenvolvia na Alemanha.

No Brasil, segundo Castro (2012, p.167), entre o século XIX e XX, a ascensão da "ordem burguesa" representou o fortalecimento do discurso voltado às "formas" inicialmente elaboradas com base no jusnaturalismo e subsequentemente defendidas pelo juspositivismo. Do ponto de vista econômico, o país presenciou a ascensão da elite cafeeira no sudeste e o declínio da produção açucareira do nordeste.

A ascensão da "ordem burguesa" coincidiu com a crescente influência sofrida pela cultura jurídica brasileira do conceitualismo do direito europeu, por meio do qual se procurou enquadrar os fatos em conceitos "prontos". A ausência de contextualização das normas as transformaram em instrumentos políticos velados visando esconder as relações de poder. (Castro, 2012, p.218)

De acordo com Castro (2012, p. 219), esta “imagem" do direito preso aos conceitos que teriam evoluído desde a antiguidade até o momento presente, voltados para a coerência interna do texto, ainda se faz presente no ensino jurídico brasileiro, o que dificulta o debate a respeito da insuficiência da forma que reveste o conceito.

Assim, a dogmática por meio de um discurso de neutralidade buscando identificar o significado abstrato do direito, sem grande preocupação com o contexto social e econômico no qual estava inserida, frequentemente, justificou a estrutura de relações e compromissos da

\footnotetext{
${ }^{65}$ A respeito da dogmática jurídica, Weber ressalta o seguinte: "The juridical point of view, or, more precisely, that of legal dogmatic aim at the correct meaning of propositions the content of which constitutes an order supposedly determinative for the conduct of a defines group of person in the words, it tries to define the facts to which this order applies and the way in which it bears upon them. Toward this end, the jurist, talking for granted the empirical validity of the legal propositions examines each of them and tries to determine its logically correct meaning in such a way all of them can be combines in a system which is logically, i. e. free from internal contradictions. This system is the 'legal order' in the juridical sense of word." (WEBER, 2005, p. 311). (Tradução nossa) O ponto de vista jurídico, ou mais precisamente da dogmática jurídica, tem por objetivo encontrar o correto significado das proposições, o conteúdo da ordem que supostamente determina a conduta de determinado grupo de pessoas e a definição dos fatos para os quais essa ordem se aplica e seu fundamento. Buscando alcançar o objetivo da norma, o jurista toma como certo a validade empírica da proposição legal isoladamente e combinada no sistema de forma lógica, ou seja, livre de contradições internas.
}

${ }^{66}$ Cf. Castro, 2012, p.182-187. 
elite, primeiro da agrária e depois da industrial, que se utilizaram das normas jurídicas, revestidas de suposta neutralidade, para assegurar a prevalência de seus interesses.

Foi em oposição a essa cultura jurídica, positivista e privatista, interessada em garantir a autonomia da vontade dos cidadãos e voltada à defesa principalmente dos direitos civis e políticos, e em menor grau dos direitos econômicos e sociais, que os constitucionalistas envolvidos na elaboração da Carta de 1988 se insurgiram. (CITTADINO, 2009, p.14-15)

Segundo Cittadino (2009, p.15), a Constituição Federal de 1988 foi fruto da "fratura" entre a visão positivista e privatista e a visão voltada para o constitucionalismo que a autora chama de comunitário ${ }^{67}$. Aquela, orientada para o fortalecimento de um constitucionalismo liberal, e esta, ansiosa em assegurar a dignidade da pessoa humana e os valores da igualdade.

Deste modo, o discurso baseado nos "valores" se fortaleceu em oposição à suposta neutralidade do discurso liberal. Embora Cittadino não empregue o termo neoconstitucionalismo para identificar o discurso dos constitucionalistas brasileiros que imprimiram maior influência no processo constituinte de $1988,{ }^{68}$ o termo passou a englobar as diversas influências do discurso constitucional influenciado pelos valores e princípios que saiu fortalecido com a promulgação da nova Carta Constitucional.

Frente a diversidade de autores, concepções e perspectivas, Humberto Ávila considera que a formulação de uma teoria a respeito do que seria o neoconstitucionalismo brasileiro seria inviável. Apesar disso, Humberto Ávila (2009, p.1-2) ${ }^{69}$ identifica, entre as diversas

67 A respeito do Comunitarismo, convém transcrever as palavras de Cittadino (2009, p.15): "Uma visão comunitária da liberdade positiva limita e condiciona em prol do coletivo a esfera da autonomia individual. Em outras palavras, os direitos fundamentais não mais podem ser pensados apenas do ponto de vista dos indivíduos, enquanto faculdades de que estes são titulares, [...] Limita e condiciona em prol do coletivo a esfera da autonomia individual.[...]."

${ }^{68}$ CF. Cittadino (2009, p.14) destaca entre os constitucionalistas "comunitários” , "José Afonso da Silva, Carlos Roberto Siqueira Campos, Paulo Bonavides, Fabio Konder Comparato, Eduardo Seabra Fagundes, Dalmo de Abreu Dallari, Joaquim Arruda Falcão Neto"

${ }^{69}$ Carbonell também identifica o que seriam "neoconstitucionalismo(s)" resultados das mudanças no próprio paradigma do Estado Liberal para o Estado Social. De acordo com o referido autor: "[c]onviene tene presente, com todo, que cuando se habla de neconstitucionalismo, ya seaen singular o em plural, se está haciendo referencia a dos cuestiones que deben estudiar-se por separado. Por uma parte, como ya se há mencionado, a uma serie de fenômenos evolutivos que han tenido evidentes impactos em lo se há llamado el paradigma des Estado constitucional. Por outro lado, com el término 'neoconstitucionalismo' se hace rferencia también a uma determinada teorá del Derecho que há propugnadi em el pasad receiente por eso câmbios y/oque da cuenta de ellos, normalmente em términos bastante positivos o inckuso elogiosos." (in. CARBONELL, 2003, p.9-10) (Tradução nossa) Convém levar em conta quando se fala de Neoconstitucionalismo no singular ou no plural, se está fazendo referência a duas questões que devem ser estudadas em separado. Por um lado, como já se mencionou, uma série de fenômenos evolutivos que tem produzido evidentes impactos no paradigma do Estado constitucional. Por outro lado, com o termo 'neoconstitucionalismo' se faz referência também a uma determinada teoria do Direito que propôs mudanças no passador recente, geralmente com resultados positivos ou mesmo elogiosos. 
abordagens que se desenvolveram no Brasil, os seguintes elementos coincidentes: (i) maior peso atribuído aos princípios em detrimento das regras; (ii) ponderação ao invés de subsunção e (iii) maior importância atribuída a atuação do Poder Judiciário em detrimento do Executivo e do Legislativo.

A fragilidade teórica e metodológica do neoconstitucionalismo, conforme adotado no Brasil, segundo Ávila (2009), residiria na adoção de "princípios" abstratos como fundamento de praticamente todas as decisões e da ausência de identificação clara a respeito de quais princípios estariam em conflito, o peso atribuído a cada um deles e quais os critérios empregados na sua escolha. Os princípios abstratos passaram a ser indicados como fundamento de praticamente todas as decisões, ainda que existisse regra clara aplicável à matéria.

A diversidade de concepções que marca boa parte do direito constitucional brasileiro recente é duramente criticada por Virgílio Afonso da Silva (2005) que a denomina de "sincretismo metodológico". Tal sincretismo consistiria na tentativa de conciliação entre as diversas teorias, algumas incompatíveis entre si, o que teria contribuído para a falta de rigor teórico e metodológico na aplicação dos princípios no debate jurídico constitucional brasileiro. ${ }^{70}$ Além disso, Virgílio critica o que denomina de "transposição" dos princípios sem a devida conexão com a realidade brasileira, com grande influência da "doutrina alemã" ${ }^{71}$

Embora Marcelo Neves identifique uma "generalização" nas críticas de Virgílio Afonso da Silva, ressalta que a aplicação de princípios capazes de afastar as regras em nome da justiça, em muitos casos, contribuiu para o fortalecimento de interesses particulares e para o enfraquecimento da norma constitucional. (NEVES, 2013, p.191)

Foi em razão das criticas formuladas por Virgílio e Humberto Ávila a respeito da ausência de uma teoria única, que se escolheu identificar nesta Dissertação o "neonconstitucionalismo na visão eclética brasileira", procurando deste modo destacar os pontos em comum às diversas abordagens, quais sejam: a valorização dos princípios sob o

\footnotetext{
${ }^{70}$ De acordo com Virgilio Afonso da Silva: “O 'sincretismo metodológico', característico do atual estágio da discussão sobre interpretação constitucional, impede que se avance na discussão acerca da tarefa da interpretação constitucional. Comum às análises sobre o tema é o fato de que esses métodos sejam apenas resumidamente explicados - não raro com base na obra de Canotilho - sem que se chegue a qualquer conclusão sobre a relação entre os diversos métodos, sua aplicabilidade e, principalmente, sobre a compatibilidade entre eles." (SILVA, 2005, p. 133-135)

${ }^{71}$ Nas palavras do autor: "Não é difícil perceber que a doutrina jurídica recebe de forma muitas vezes pouco ponderada a as teorias desenvolvidas no exterior. E, nesse cenário, a doutrina alemã parece gozar de uma posição privilegiada, já que, por razões desconhecidas, tudo o que é produzido na literatura germânica parece ser encarado como revestido de uma aura de cientificidade e verdade indiscutíveis". (SILVA, 2005, p.116)
} 
aspecto moral e o emprego dos mesmos como fundamento de destaque da decisão judicial, muitas vezes com pouca ou nenhuma identificação com a realidade.

Assim, enquanto a dogmática adotava conceitos prontos, revestidos de "neutralidade", o neoconstitucionalismo, na visão eclética brasileira, conduziu a discussão jurídica à esfera moral tratada com grande abstração e, embora procurasse a efetivação da justiça, muitas vezes, no caso concreto, terminou por dificultar a fruição de direitos em razão da fragilidade dos próprios fundamentos com que a abordagem eclética trabalha. Em ambos os casos (dogmática constitucional e neoconstitucionalismo), a ausência de foco analítico na dimensão econômica da fruição do direito em questão termina por enfraquecer o próprio exercício deste, uma vez que não explora analiticamente as possibilidades de reformas institucionais capazes de assegurar a fruição empírica do direito em questão. ${ }^{72}$

A seguir, será apresentada breve análise a respeito dos referenciais analíticos extraídos da decisão proferida pelo STF no julgamento da ADI $\mathrm{n}^{\mathrm{a}} 3.768-4$, com vistas a exemplificar de que modo o discurso predominante na cultura jurídica brasileira influenciada pela dogmática e pelo neoconstitucionalismo se revela insuficiente para operar uma verdadeira mudança da realidade social.

\subsection{Um caso exemplar}

O caso analisado na presente Seção diz respeito à Ação Direta de Inconstitucionalidade $n^{\circ}$ 3.768-4, ajuizada em 2006 pela Associação Nacional das Empresas de Transportes Urbanos (NTU). A NTU pleiteava, em apertada síntese, a não aplicabilidade imediata do art. 39 da Lei $n^{\circ}$ 10.741/2003 (Estatuto do Idoso) em razão da ausência de lei prevendo a compensação financeira para adoção da medida visando à gratuidade do transporte público urbano para pessoas com mais de sessenta e cinco anos de idade. Segundo a NTU, a concessão de gratuidade estaria condicionada à indicação da respectiva fonte de custeio,

\footnotetext{
72 Neste mesmo sentido, a crítica formulada por CASTRO (2009, p.6), a seguir colacionada: “A seu turno, a 'ponderação de valores', sendo de caráter genérico e abstrato, acaba se apoiando em especulações imprecisas sobre o que são os 'valores' em questão, e sobre qual a maneira de ajuste mútuo entre eles que seria mais adequada para atender aos interesses concretos dos membros da sociedade. [...]
} 
conforme precedente estabelecido no julgamento da Ação Direta de Inconstitucionalidade $\mathrm{n}^{\circ}$ $2.733-6 .^{73}$

Com vistas a situar o leitor, cumpre registrar que a ADI n 2.733-6, ajuizada em 2002 pelo Governador do Estado do Espírito Santo, pleiteava a declaração de inconstitucionalidade de lei estadual que excluiu a obrigatoriedade do pagamento de pedágio para motociclistas e concedeu o desconto de 50\% na tarifa para estudantes sob o argumento de que tal medida comprometeria o equilíbrio econômico financeiro dos contratos de concessão celebrados antes de sua vigência, além de representar violação ao "princípio constitucional da harmonia entre os poderes". ${ }^{74}$

O acórdão que declarou a inconstitucionalidade da lei estadual na ADI n 2.733-6, embora tenha considerado a ausência de indicação de fonte de custeio, apresentou como principal fundamento a suposta violação ao princípio da harmonia entre os poderes, pois o relator entendeu que as condições para a celebração dos contratos de concessão, nelas incluídas a indicação das fontes de custeio, estariam inseridas na competência do poder concedente. $^{75}$

${ }^{73}$ Os Pedidos foram assim formulados na Inicial: "Quanto ao mérito, a autora requer que este Supremo Tribunal Federal:

a) Adotando a técnica de interpretação conforme do art. 39, caput, do Estatuto do Idoso, sem redução do texto, declare inconstitucional a aplicação dessa norma ao serviço de transporte coletivo urbano prestado no regime de permissão ou concessão, haja vista a ausência de norma federal específica instituindo um mecanismo compensatório da gratuidade $\mathrm{OU}$

b) Aplicando-se o art. 27 da Lei $9.868 / 99$ e, reconhecendo -se uma omissão parcial do art. 39 da Estatuto do Idoso, declare inconstitucional a incidência do referido preceito legal ao transporte coletivo urbano prestado no regime de permissão ou concessão enquanto não ou até que_sobrevenha norma federal específica instituindo o mecanismo de compensação da gratuidade; $\underline{\mathbf{E}}$

c) Em julgando improcedentes os pedidos deduzidos nos itens ' $a$ ' e ' $b$ ' acima, que declare inconstitucional o art. 39 do Estatuto do Idoso, por frontal violação aos arts. 37, XXI, 175 e 195, § 5 , da Carta da República." (grifos no original)

74 O voto do Relator da ADI n ${ }^{\circ}$ 2.733-6, Ministro Eros Graus, acolheu os argumentos do autor e considerou que a lei de iniciativa do Poder Legislativo Estadual que criou tratamento tarifário diferenciado, sem a correspondente fonte de custeio, violou o equilíbrio econômico-financeiro dos contratos. Como precedente, indicou a ADI/MC no 2.999/2003 que considerou inconstitucional lei estadual que concedeu isenção ao pagamento de energia elétrica e água aos trabalhadores desempregados no Rio Grande do Sul. Ainda de acordo com Eros Grau, a lei estadual de inciativa do legislativo que concedeu desconto de $50 \%$ nas tarifas inovou na relação contratual estabelecida entre o Poder Concedente (Executivo) e as concessionárias, resultando não apenas em quebra do equilíbrio econômico-financeiro, mas sobretudo em afronta ao Princípio Constitucional de Harmonia dos Poderes. O voto do Relator foi acompanhado pelos demais Ministros. Disponível em< http://redir.stf.jus.br/paginadorpub/paginador.jsp?docTP=AC\&docID=266908 > Acesso em 15 de jun. de 2015.

75 De acordo com o voto do Relator Eros Grau: [o] “ tema da manutenção da equação econômico-financeira foi abordado pela Corte no julgamento de outra ação direta, na qual se discutiu a constitucionalidade de lei estadual que concedeu isenções de pagamento de consumo de energia elétrica e água a trabalhadores desempregados, no âmbito do Estado do Rio Grande do Sul. O Ministro Moreira Alves, Moreira Alves, Relator, destacou então que:

'Com efeito, em exame compatível com a natureza da liminar requerida, Lei estadual, máxime quando diz respeito à concessão de serviço público estadual e municipal, como ocorre no caso, não pode alterar as condições da relação contratual entre o poder concedente e os concessionários sem causar descompasso entre a tarifa e a 
Ao tratar do desiquilíbrio econômico financeiro nos autos da ADI n 3.768-4, a NTU, utilizando-se do suposto precedente consubstanciado na ADI $\mathrm{n}^{\circ}$ 2.733-6, considerou os aspectos econômicos tão somente sob o ponto de vista dos concessionários, sem que fossem levados em conta os correspondentes reflexos para os usuários dos serviços de transportes.

Além da indicação do precedente consubstanciado na ADI $n^{0}$ 2.733-6, a NTU sustentava que o uso do transporte público urbano seria um direito não de primeira geração (direitos civis e políticos ou liberdades públicas), mas sim de segunda geração. Enquanto direito de segunda geração, segundo a NTU, o direito à gratuidade seria espécie de direito social com fundamento nos princípios da solidariedade e da fraternidade, ligados à assistência social.

Por fim, sustentava que a gratuidade deveria ser regulamentada por meio de lei municipal, pois competiria ao governo local adotar as medidas necessárias, legislativas e administrativas, para assegurar a efetividade do referido direito, posto que o transporte público urbano está inserido na esfera de competência dos municípios, de acordo com a Constituição Federal. $^{76}$

A relatoria da ADI no 3.768-4 ficou a cargo da Ministra Carmem Lúcia. Segundo seu entendimento, o Estatuto do Idoso apenas conferiu efetividade a um direito já contido no texto constitucional (art. 230, $\S 2^{\circ}$ ), razão pela qual não estaria submetido ao entendimento consignado na ADI $n^{\circ}$ 2.733-6, pois enquanto a lei estadual do Espirito Santo concedeu desconto de $50 \%$ após a celebração dos contratos de concessão, a Constituição Federal de 1988 já havia consignado o referido direito à gratuidade, de modo que os contratos celebrados posteriormente deveriam prever tal medida e os celebrados antes da CRFB de 1988 deveriam

\footnotetext{
obrigação de manter serviço adequado em favor dos usuários, infringindo, não só a política tarifária estabelecida contratualmente e sob o controle do poder concedente, mas também introduzindo elementos no na relação contratual [...] (ADI/MC no 2.999, Relator o ministro Moreira Alves, DJ de 28/08/2003.)' [...]

A afronta ao princípio da harmonia entre os poderes é evidente na medida em que o Poder Legislativo pretende substituir o Executivo na gestão dos contratos por este celebrados, introduzindo alterações unilaterais em contratos por este celebrados [...]" voto na DI $\mathrm{n}^{\circ}$ 3.367." (Disponível em $<$ http://redir.stf.jus.br/paginadorpub/paginador.jsp?docTP=AC\&docID=266908) > Acesso em 15 de mar. de 2015.)

${ }^{76}$ De acordo com a Inicial, as delegatárias sustentavam a existência de direito constitucional acerca da "previsão normativa de uma compensação sempre que a lei impuser aquelas pessoas de direito privado a perda da receita esperada e atrelada à política tarifária que orienta o equilíbrio econômico-financeiro dos respectivos contratos administrativos.” (ADI 2733, Rel. Min. Eros Grau, ADI MC 2299-, Rel. Ministro Moreira Alves).

Disponível

em $<$ http://redir.stf.jus.br/estfvisualizadorpub/jsp/consultarprocessoeletronico/ConsultarProcessoEletronico.jsf?seqo bjetoincidente $=2396731>$ Acesso em 10 de jan. de 2014
} 
se adaptar as suas determinações, motivo pelo qual deveria ser afastado o referido precedente. $^{77}$

Em sua manifestação, a relatora citou a Nota Técnica exarada pelo Ministério do Desenvolvimento Social e Combate a Fome, na qual foram apresentados os dados colhidos pela Secretaria de Assistência Social daquele Ministério, indicando que em julho de 2006 cerca de um milhão, cento e trinta e oito mil e quatro idosos perceberam "benefício não contributivo de assistência social" o que representa o contingente de idosos de baixa renda no Brasil, vulneráveis econômica e socialmente, e que utiliza precipuamente o transporte coletivo gratuito. Nas palavras da ilustre Ministra do STF:

O transporte gratuito, especialmente para os idosos que sobrevivem de aposentadorias insuficientes para o suprimento de suas necessidades básicas, apresenta-se como verdadeiro suporte para que possam exercer, sem menores dificuldades, seu direito de ir e vir. ${ }^{78}$ (grife-se)

Destarte, consoante a manifestação da relatora, o direito à gratuidade dos transportes para os idosos foi inserido na Constituição Federal pelo próprio constituinte originário e ostentaria eficácia plena e aplicabilidade imediata, sem a necessidade de qualquer outra norma tratando da matéria. Segundo Carmem Lúcia, o suposto desequilíbrio econômico-financeiro resultante da ausência de indicação de fonte de custeio, conforme argumento apresentado pela NTU, deveria ser comprovado pelas empresas responsáveis pelo transporte público caso a caso. Todavia, segundo a ilustre relatora, mesmo comprovado o eventual desequilíbrio econômico-financeiro, isto por si só não seria motivo para limitar o direito à gratuidade dos

\footnotetext{
77 Nas palavras da Relatora: "De outra parte, não há direito adquirido a se contrapor a direitos previstos constitucionalmente, como os que se referem aos idosos. Logo, mesmo nos contratos de concessão ou permissão assinados antes da promulgação da Constituição, em respeito à garantia de equilíbrio, o máximo que poderiam requerer os delegados dos serviços de transporte municipal e intermunicipal seria da alteração dos contratos para cobrir-se , financeiramente, com os ônus comprovados em planilhas sobre o uso dos transportes delegados pelos idosos. Teriam, para tanto, de provar quantos e em que condições aqueles serviços onerariam os seus contratos." (Disponível em <http://redir.stf.jus.br/paginadorpub/paginador.jsp?docTP=AC\&docID=491812 > Acesso em 14 de mar de 2015.)

${ }^{78}$ Disponível em< http://redir.stf.jus.br/paginadorpub/paginador.jsp?docTP=AC\&docID=491812 >Acesso em 14 de mar. De 2015.
} 
idosos, posto que, segundo Carmem Lúcia, os custos advindos da gratuidade já estariam incluídos nos estudos de viabilidade do negócio e, portanto, na fixação da política tarifária. ${ }^{79}$

Com relação ao argumento coligido pela NTU a respeito da caracterização do direito à gratuidade do transporte como direito assistencial, a Ministra Carmem Lúcia, sem se aprofundar nos aspectos econômicos, afastou o argumento em razão da disposição dos artigos no texto constitucional. ${ }^{80}$

A manifestação da Relatora revela inegável influência do dogmatismo jurídico, posto que desconsidera o argumento da NTU em razão da localização do dispositivo no texto constitucional. A influência da dogmática, a propósito, será uma constante nos votos os demais julgadores, mesmo quando estes consideram como fundamento principal da decisão certos princípios e valores constitucionais, como ocorre no pronunciamento do Min. Celso de Mello, apresentado adiante.

Acompanharam o voto da relatora, os Ministros Ricardo Lewandowski, Carlos Brito, Cezar Peluso, Gilmar Mendes, Ellen Gracie, Celso Mello, Menezes Direito e Joaquim Barbosa. Vencido o Ministro Marco Aurélio de Mello. ${ }^{81}$

Embora o voto da relatora tenha sido acompanhado pela maioria dos ministros, a formatação das decisões proferidas pelo STF permite que julgadores apresentem diferentes fundamentos jurídicos para a decisão, alguns incompatíveis entre si.

Os argumentos apresentados pelo Ministro Celso de Mello corroboraram a manifestação da relatora no sentido de que a Constituição valeria como marco regulatório das concessões/ permissões e que a norma contida no $\S 2^{\circ}$ do art. 230 da CF possuiria eficácia plena e imediata. Por outro lado, o referido ministro ressalta que o direito à gratuidade teria como

\footnotetext{
${ }^{79}$ Nas palavras de Carmem Lúcia: "Ademais, após a promulgação da Constituição da República, todos os concessionários e permissionários estão submetidos às suas normas, não podendo, desde então, alegar que não sabiam do direito dos idosos ao transporte coletivo gratuito.

Mas ainda, os custos advindas da gratuidade fazem parte dos estudos de viabilidade do negócio assumido pelo particular e estão incluídos entre os custos do serviço, os quais são tidos, como ponderado pelo Advogado-Geral da União, 'como fator importante na fixação da política tarifária, os aspectos econômicos atinentes à efetivação de tal direito' fl.158)" $\quad$ Disponível em< http://redir.stf.jus.br/paginadorpub/paginador.jsp?docTP=AC\&docID=491812> Acesso em 14 de mar. de 2015.
}

\footnotetext{
${ }^{80}$ De acordo com Carmem Lúcia: “A despeito de estarem dispostas no Título VIII da Constituição da República, que trata da Ordem Social, as disposições relativas à seguridade social (saúde, previdência e assistência social), previstas no Capítulo II, não se confundem com aquelas afeitas aos idosos, situadas no Capítulo VI, sendo correto, por isso mesmo, afirmar que as normas constitucionais atinentes à seguridade social (arts. 194 a 204) não são aplicáveis à específica disciplina do direito aos idosos (art.230)" Disponível em < http://redir.stf.jus.br/paginadorpub/paginador.jsp?docTP=AC\&docID=491812> Acesso em 14 de mar. de 2015.
}

81 Cf. Extrato da Ata, p. 631. Disponível em <http://redir.stf.jus.br/paginadorpub/paginador. jsp?docTP=AC\&docID=491812 >. Acesso em 12 de dez. de 2014. 
fundamento o princípio da solidariedade, embora a relatora tenha afastado a "natureza" assistencial do direito à gratuidade.

De acordo com o Ministro Celso de Melo, cujo voto destaca-se a seguir, o princípio da solidariedade atuaria como vetor para a proteção dos idosos que devem ser amparados pela família e pelo Estado. ${ }^{82}$ Pela leitura do voto de Celso de Melo, percebe-se que o ministro considerou o principio sob o enfoque moral, em discurso que revela inegável influência do neoconstitucionalismo na visão eclética difundida no Brasil, os reflexos econômicos da aplicação do princípio supramencionado, contudo, não são abordados pelo julgador. Os reflexos econômicos relacionados à aplicação do princípio da solidariedade serão abordados no próximo item desta Dissertação.

Além do voto do Ministro Celso de Mello, outro pronunciamento que merece destaque é o voto do Ministro Cezar Peluso que, embora tenha consignado a necessidade de se "discutir mecanismos, meios e modos de financiamento", ressalvando que tais meios não podem se basear apenas na expansão tarifária, concluiu sua manifestação sustentando que a indicação sobre quem arcará com o ônus financeiro estaria limitada à esfera política e que, portanto, escaparia ao debate jurídico. ${ }^{83}$

Em oposição ao entendimento da maioria, o ministro Marco Aurélio de Mello julgou procedente o pedido para excluir a interpretação que conduzisse à atribuição do ônus relativo à gratuidade sobre a pessoa jurídica que prestasse o serviço público ou sobre os demais usuários deste serviço, cabendo ao Estado arcar com o custo da gratuidade. Embora a manifestação de Marco Aurélio insista em que o debate a respeito das fontes de financiamento apresenta aspectos jurídicos, por outro lado, seu pronunciamento foi, por assim dizer, no mínimo contraditório, pois ao mesmo tempo em que insiste na necessidade de que o ônus da gratuidade não recaia sobre os concessionários ou sobre a sociedade, pois esta já pagaria

\footnotetext{
${ }^{82}$ De acordo com Celso de Melo, “[...] o princípio as solidariedade, que constitui um dos objetivos fundamentais da República, rege, informa e permeia o texto de nossa Constituição, erigindo-se, por isso mesmo, como expressivo vetor interpretativo de suas cláusulas, notadamente aquela que dispensa proteção às pessoas idosas, que devem ser amparadas pela família, pelo Estado e, também, pela sociedade." VOTO Ação Direita de Inconstitucionalidade 3768-4 Distrito Federal, p. 628-629.

Disponível em <http://redir.stf.jus.br/paginadorpub/paginador.jsp?docTP=AC\&docID=491812> Acesso em 12 de dez. de 2014.

${ }^{83}$ Segundo Gilmar Mendes, “ o licitante [que] entrou na licitação e a venceu, sabendo que teria de suportar esse custo decorrente da norma constitucional. O resto é só discussão de como se resolve politicamente quem vai pagar ou não, etc. No fundo, todos nós pagamos, e é o que a norma diz: que o estado e a sociedade devem pagar." VOTO Ação Direita de Inconstitucionalidade 3768-4 Distrito Federal, p.622-623. Disponível em <http://redir.stf.jus.br/paginadorpub/paginador.jsp?docTP=AC\&docID=491812 >Acesso em 15 de dez. de 2014.
} 
tributos, o ilustre julgador conclui no sentido de que o ônus deve ser arcado pelo Estado. ${ }^{84}$ Obviamente, o Estado, para arcar com o ônus, necessita cobrar tributos dos contribuintes (ou endividar-se, ou emitir moeda, em qualquer caso, consequências que necessitariam ser claramente consideradas).

Ou seja, ao atribuir o ônus ao Estado, o julgador está, em última análise, transferindo esse mesmo ônus para a sociedade que deverá arcar com as despesas por meio de novos tributos ou aumento das alíquotas dos tributos existentes. Portanto, na argumentação do tribunal, não se vislumbrou outra hipótese de financiamento.

Pode-se ainda dizer, especulativamente, que o voto comentado estaria contemplando tacitamente a possibilidade de prestação direta do serviço pelo Estado. Contudo, tal possibilidade não parece ter qualquer respaldo, visto que o exercício da atividade de forma direta representaria o fim da própria concessão do serviço público de transporte.

A despeito da contradição indicada no voto do Ministro Marco Aurélio, convém destacar que este reconheceu a necessidade de se discutir ou, melhor, rediscutir a relação atuarial da prestação do serviço, sem aceitar o argumento de que tal questão já fora definitivamente resolvida pela previsão da gratuidade no texto constitucional, conforme sustentara os demais ministros. ${ }^{85}$

Ao decidir os casos relacionados à fruição de direitos fundamentais com fundamento em conceitos abstratos, sem se preocupar com o contexto social, político e econômico, o Supremo Tribunal Federal, no caso apresentado, se esquivou de aprofundar a análise de questões de cunho econômico.

O não enfrentamento dos contornos econômicos e políticos relacionados ao direito fundamental de ir e vir, cuja fruição era o objetivo da politica pública de gratuidade de

\footnotetext{
${ }^{84}$ Sustenta o Ministro: "O que decorre da gratuidade não há de ser sustentado pela sociedade em si. Esta já satisfaz, numa gradação insuplantável, os impostos e os tributos. Deve ser arcado pelo próprio Estado." VOTO Ação Direita de Inconstitucionalidade 3768-4 Distrito Federal, p.622-623. Disponível em $<$ http://redir.stf.jus.br/paginadorpub/paginador.jsp?docTP=AC\&docID=491812 >Acesso em 25 de junho de 2015.

${ }^{85}$ Conforme declarado no voto do Min. Marco Aurélio: "Volto à pergunta: como fica a relação atuarial, ante a prestação do transporte na via não direta mas indireta, mediante atuação de pessoa jurídica de direito privado? Será que a Carta da República, será que o Estado acabou por prever e inserir, ele próprio, no contexto da definição da matéria, que esse ônus será arcado [...] por aqueles que contém menos de 65 anos, pela prestadora dos serviços? A resposta, para mim é negativa. Toda vez que o Estado prevê a gratuidade, a menos que desprezamos os contornos, a interpretação sistemática da Constituição Federal, deve dar os meios para se alcançar esse objetivo." VOTO Ação Direita de Inconstitucionalidade 3768-4 Distrito Federal, p. 624-627. Disponível em <http://redir.stf.jus.br/paginadorpub/paginador.jsp?docTP=AC\&docID=491812> Acesso em 12 de jan. de 2014.
} 
transportes para idosos, não fez com que tais questões desaparecerem, mas transferiu o enfrentamento das mesmas para a esfera política ou tecnocrática.

$\mathrm{O}$ item seguinte cuidará de alguns aspectos econômicos relacionados à política de gratuidade do transporte publico para idosos; registre-se, desde já, que não se tem a pretensão de esgotar o assunto, mas tão somente possibilitar ao leitor a reflexão a respeito dos aspectos envolvidos em tal política, nem sempre considerados pelo legislador ou pelo policy maker.

\subsection{Superficialidade no tratamento da dimensão econômica}

Outras considerações acerca da temática sobre a qual se debruçaram as análises oferecidas pelos julgadores do caso comentado merecem ser registradas.

Ao se furtar a debater mais cuidadosamente os aspectos econômicos da atividade de transporte público urbano, tais como as fontes de custeio para a gratuidade do serviço em relação a pessoas acima de sessenta e cinco anos, o STF perdeu a oportunidade de discutir os critérios para o financiamento da fruição do direito, cuja análise não deve ser relegada apenas ao ambiente político ou à tecnocracia econômica. Especialmente esta última (tecnocracia econômica) ordinariamente não põe ênfase em preocupações que avancem na direção de tornar a economia "justa". Inversamente a isto, o tribunal - como visto acima - enfrenta dificuldades em tornar economicamente viáveis eventuais medidas de justiça.

A manifestação da Relatora ao desconsiderar o direito à gratuidade do transporte como incluído nas disposições relativas à assistência social fundamentou-se nos referenciais da dogmática jurídica objetivando afastar tão somente as supostas contradições internas ao texto.

De acordo com o art. 194 da CRFB, a seguridade social compreende um conjunto integrado de ações dos Poderes Públicos e da sociedade destinadas a assegurar os direitos à saúde, à previdência e à assistência social. Os direitos inseridos na assistência social encontram suas diretrizes no artigo 204 e seguintes da Constituição Federal. Conforme disposto no art. 204 da CRFB, as ações na área de assistência social serão custeadas com recursos do orçamento da seguridade social e outros, in verbis:

Art. 204. As ações governamentais na área da assistência social serão realizadas com recursos do orçamento da seguridade social, previstos no art. 195, além de outras fontes, e organizadas com base nas seguintes diretrizes: 
Não por acaso, a Associação Nacional das Empresas de Transportes Urbanos procurou demonstrar a relação entre a gratuidade e a assistência social, pois tal demonstração, segundo a perspectiva de argumentação adotada, afastaria a responsabilidade das concessionárias e permissionárias de arcar com os ônus financeiros do serviço oferecido a idosos.

A preocupação com a "localização textual" do dispositivo citado reflete a visão segundo a qual o direito, no caso o direito constitucional, consistiria em um "sistema" cujo objetivo é exercer um papel " politicamente unificante”. A chamada interpretação sistemática, nos moldes defendidos por Savigny, teria a função de "revelar" as pretensões ontológicas que se ocultavam sob as formas supostamente coesas e que teriam se desenvolvido ao longo da história. (Castro, 2012, p.148-149). ${ }^{86}$

O julgador na tentativa de "revelar" o sentido da norma se afasta da análise do contexto social no qual a implementação desta se insere, ao mesmo tempo em se aproxima do formalismo extremo; no caso em tela, a Ministra Carmem Lúcia afasta os argumentos a respeito do financiamento com recursos previdenciários ao negar a "natureza" previdenciária da norma, que não se encontra em determinado dispositivo constitucional. ${ }^{87}$

Além disso, a manifestação da relatora não fez qualquer menção à renda dos beneficiários, adotando desta vez a interpretação literal a respeito do direito ao transporte coletivo urbano gratuito, cujo fundamento residiria (segundo entendeu a relatora) tão somente na idade das pessoas, e não em sua renda. ${ }^{88}$

Deste modo, uma pessoa acima de 65 anos, de acordo com a interpretação literal do dispositivo constitucional adotada ao final pelo STF, mesmo tendo recursos para arcar com a

\footnotetext{
${ }^{86}$ De acordo com Castro (2012, p.149) a noção de "instituto" jurídico concebido como um conjunto de relações que existiriam espontaneamente na sociedade desde a Antiguidade, competindo ao juristas tão somente revelálas, se mostra inadequada para determinar o sentido prático de textos normativos, que na realidade não formam um sistema discursivo coerente e completo.

${ }^{87}$ Castro (2012, p.154) ressalta que a forte influência no Brasil da Escola Histórica Alemã e do conceitualismo do século XIX se reflete na permanência de disciplinas denominadas "Teoria Geral do Direito" nas faculdades de direito brasileiras. De acordo com o referido autor, a permanência desse referencial tem como consequências: "(i) o fechamento do estudo do direito sobre os seus próprios conceitos formais; (ii) a consequente dificuldade de conciliar o ensino do direito com outras disciplinas,; e (iii) a dificuldade de absorver a pesquisa empírica e seus frutos para o campo do direito como conjunto de práticas intelectuais." ( nota de rodapé)

${ }^{88}$ Dispõe o $\$ 2^{\circ}$ do art. 230 da CRFB:
}

Art. 230. A família, a sociedade e o Estado têm o dever de amparar as pessoas idosas, assegurando sua participação na comunidade, defendendo sua dignidade e bem-estar e garantindo-lhes o direito à vida.[...]

$\S 2^{\circ}$ - Aos maiores de sessenta e cinco anos é garantida a gratuidade dos transportes coletivos urbanos. (grife-se) 
tarifa, ainda assim, será beneficiária do direito ao transporte coletivo urbano gratuito. Portanto, na ótica de uma interpretação "literal" da CRFB, para exercer o direito bastaria à pessoa contar com mais de 65 anos, sem maiores discussões a respeito sobre quem de fato responderia pelo ônus.

A distribuição do ônus das gratuidades do transporte público urbano foi objeto de estudos do Instituto de Pesquisa Econômica Aplicada (IPEA). Segundo o referido instituto, a partir do final da década de 1980, a tarifa de ônibus urbanos passou a responder quase que exclusivamente pelo custeio do referido transporte no Brasil, poucos sendo os recursos extratarifários utilizados no financiamento do setor. (VASCONCELLOS et al, 2011, p.41)

O modelo de financiamento baseado exclusivamente nas tarifas causa várias distorções, dentre as quais se destacam a perda de demanda e a sobretaxa aos passageiros pagantes. A perda de demanda consiste no afastamento de parcela de usuários em razão do aumento do valor da tarifa, pois tal aumento gera grande impacto para a população de menor renda, que constitui a maior parte dos usuários de transportes coletivos. Assim, a majoração do preço da passagem termina por afastar a população de menor poder aquisitivo, reduzindo o número de usuários e tornando a passagem, consequentemente, mais dispendiosa para aqueles que continuam usando os serviços; gerando um círculo vicioso. (CARVALHO et al, 2013, p.11-12)

A seu turno, a sobretaxa resultante de benefícios cruzados ocorre quando usuários de menor renda são obrigados a arcar com o custo de gratuidade, incluindo para idosos de renda mais alta, visto que o direito, conforme assinalado anteriormente, foi reconhecido pelo STF às pessoas com mais de 65 anos, independentemente de sua faixa de renda. Neste caso o usuário que paga integralmente a tarifa arca com os custos dos demais usuários não pagantes, o que torna o sistema cada vez mais regressivo. (CARVALHO et al, 2013, p.11-12)

O descompasso entre os múltiplos aspectos da realidade também pode ser verificado na aplicação dos princípios pelo ilustre min. Celso de Mello, conforme já mencionado anteriormente. Embora o referido Ministro tenha acompanhado o voto da relatora, que negou a hipótese de direito de cunho assistencial, Celso de Mello sustentou que o direito à gratuidade teria sua origem no "princípio da solidariedade".

Insta registrar que, além do aspecto moral, o princípio da solidariedade constitui-se em um dos principais, senão o principal, fundamento das discussões a respeito de sistemas contributivos, em especial o sistema da seguridade social, que engloba governo, sociedade e beneficiários da previdência, atribuindo-se peso à contribuição de cada um deles. 
O princípio da solidariedade, além do conteúdo moral, suscita a possibilidade de distribuição do ônus financeiros entre os partícipes do sistema, garantindo-se que o gozo do benefício por uns será assegurado pela contribuição dos demais. ${ }^{89}$

Destarte, ao fundamentar a decisão no princípio da solidariedade, apenas considerando o aspecto moral, o julgador se olvida da dimensão econômica própria do sistema, no caso o financiamento de transporte urbano. Neste caso, o julgador deveria estabelecer (ou ao menos indicar a necessidade de se estabelecer) o peso da participação de cada um dos sujeito nominados: concessionários, usuários e governo. A ausência de debate a respeito do ônus, por afastar a transparência, contribui para que a gratuidade seja custeada apenas pelos demais usuários do sistema de transporte público, possibilitando a ampliação de lucros para uns e reforçando a regressividade do sistema para outros, conforme indicado no estudo do IPEA. (CARVALHO et al, 2013, p.11-12)

Como se percebe, a decisão proferida pelo STF no julgamento da ADI n ${ }^{\circ} 3.768-4$, no tocante aos reflexos econômicos da concessão da gratuidade do serviço de transporte de passageiros foi, por assim dizer, superficial, não tendo se aprofundado no debate das fontes de financiamento para o serviço de transporte público, além da própria tarifa.

Mesmo a manifestação do Ministro Marco Aurélio que busca excluir a responsabilidade pelo ônus dos usuários pagantes, das concessionárias de transporte e da sociedade em geral, atribuindo unicamente ao Estado a responsabilidade pelas despesas resultantes da gratuidade, esbarra novamente na questão já apontada no texto: de que modo o Estado assumiria o ônus, sem que o mesmo fosse repassado para a sociedade na forma de mais impostos? A primeira hipótese consistiria na assunção direta da prestação do serviço de transporte (encampação) ${ }^{90}$, o que representaria o fim da própria concessão do serviço. Esta hipótese, contudo, não encontra qualquer respaldo na decisão proferida pelo Egrégio Tribunal.

\footnotetext{
${ }^{89}$ A respeito da Solidariedade (art. $3^{\circ}, \mathrm{I}$ da $\mathrm{CF} / 88$ ), insta registrar que “ [s]em dúvida, é o princípio securitário de maior importância, pois traduz o verdadeiro espírito da previdência social: a proteção coletiva, na qual as pequenas contribuições individuais geram recursos suficientes para a criação de um manto protetor sobre todos, viabilizando a concessão de prestações previdenciárias em decorrência de eventos preestabelecidos. [...]

A solidariedade é a justificativa elementar para a compulsoriedade do sistema previdenciário, pois os trabalhadores são coagidos a contribuir em razão da cotização individual ser necessária para a manutenção de toda a rede protetiva, e não para a tutela do indivíduo, isoladamente considerado." (IBRAHIM, 2008, p. 55)

${ }^{90}$ Encampação é definida no o art. 37 da Lei no $8987 / 98$ nos seguintes termos:
}

Art. 37. Considera-se encampação a retomada do serviço pelo poder concedente durante o prazo da concessão, por motivo de interesse público, mediante lei autorizativa específica e após prévio pagamento da indenização, na forma do artigo anterior. 
Embora a manifestação de Marco Aurélio seja contraditória a respeito da assunção do ônus da gratuidade pelo Estado, a preocupação em excluir a responsabilidade dos usuários pagantes pelo ônus suscita o questionamento a respeito de outras fontes de financiamento, além da própria tarifa do transporte público urbano, o que também foi objeto de estudo do IPEA.

O estudo realizado pelo IPEA apresenta as seguintes fontes alternativas: recursos provenientes do orçamento geral, fundos vinculados a outras políticas públicas, taxa sobre o combustível, taxa sobre o uso da via sujeita a congestionamento, cobrança de estacionamentos em vias públicas, cobrança de estacionamentos em espaços privados, tributos incidentes sobre a produção, comercialização e propriedades dos veículos individuais, vale transporte, tributo com base na folha de pagamento de empresas, instrumento de captura de valor e atividades geradoras de renda associadas ao transporte. Os pesquisadores ressaltam, contudo, a necessidade do aprofundamento dos estudos antes da aplicação das medidas propostas. (CARVALHO et al, 2013, p.16-18)

Importante registrar que todas as medidas supramencionadas embora possam contribuir para reduzir a regressividade do sistema de tarifas de transporte público, preveem a contribuição da sociedade sob a forma de pagamento de valores (impostos, taxas, pedágios, etc) ou por meio da isenção de tributos, o que também atrai a necessidade de realocação das receitas arrecadadas pelo Estado, o que evidencia o descompasso entre o voto do Ministro Marco Aurélio e as hipóteses de financiamento do sistema.

Entre as fontes extratarifárias apontadas pelo estudo do IPEA, uma merece maior destaque, trata-se da utilização de recursos arrecadados a título de Contribuição de Intervenção do Domínio Econômico (CIDE) como fonte de financiamento para o transporte. O destaque atribuído por esta Dissertação à CIDE visa demonstrar o descompasso entre a aplicação dos recursos sob o ponto de vista fático e a justificativa para tanto. ${ }^{91}$

\footnotetext{
${ }^{91}$ Contribuição de Intervenção sobre o Domínio Econômico (CIDE) foi criada pela Emenda Constitucional (EC) $\mathrm{n}^{\circ} 33$, de 11 de dezembro de 2001. De acordo com o art. 177, § $4^{\circ}$, inciso II da CRFB, os recursos da CIDE devem ter a seguinte destinação.

Art. $177[\ldots]$

II - os recursos arrecadados serão destinados:

a) ao pagamento de subsídios a preços ou transporte de álcool combustível, gás natural e seus derivados e derivados de petróleo;

b) ao financiamento de projetos ambientais relacionados com a indústria do petróleo e do gás;

c) ao financiamento de programas de infra-estrutura de transportes. (grifou-se)
} 
Ao se debruçar a respeito da questão referente às fontes de financiamento das passagens de ônibus, a Nota Técnica elaborada por pesquisadores do IPEA (CARVALHO et al, 2013, p.19) suscita breve questionamento a respeito da utilização de recursos da CIDE como fonte de financiamento para o transporte público. Os pesquisadores apresentam soluções para o que chamam de impossibilidade de se utilizar os recursos da CIDE diretamente no custeio da tarifa de transporte, embora não esclareçam o que entendem por impossibilidade. $^{92}$

Antes de se analisar os motivos da suposta impossibilidade, apresenta-se ao leitor a solução apontada pelos pesquisadores, qual seja: a utilização dos recursos para pagamento de subsídio cruzado na cadeia de derivados, o que acarretaria a redução do preço do diesel, por exemplo. Deste modo os recursos não seriam utilizados diretamente no custeio das tarifas, mas tornariam estas menos dispendiosas, uma vez que a CIDE não seria recolhida na comercialização de diesel, combustível utilizado pelos ônibus. ${ }^{93}$.

Uma vez que o texto do IPEA não esclarece os motivos da suposta impossibilidade, convém destacar que a interpretação literal conferida ao texto do dispositivo constitucional e ao artigo $1^{\circ}$ da lei $\mathrm{n}^{\mathrm{o}} 10.336$, de 19 de dezembro de $2001,{ }^{94}$ que definiu a aplicação da CIDE,

92 O trecho que trata da suposta impossibilidade foi redigido nos seguintes termos: "No Brasil existe o mecanismo da CIDE, que tem como destino investimentos em infraestrutura e, a priori, não poderia financiar a operação dos serviços. Ainda assim, existe a possibilidade de subsídios cruzados a cadeia de derivados, que acarretaria a redução do preço do diesel vendido aos operadores [...] “(CARVALHO et al, 2013, p.19).

${ }^{93}$ De acordo com proposta apresentada em 2009 pela NTU, a alíquota zero da CIDE apenas para o diesel utilizado no transporte público coletivo poderia ser compensado pelo aumento da alíquota em $5 \%$ do preço da gasolina, correspondendo a subsídio cruzado para reduzir em $50 \%$ do preço do diesel. De acordo com a Nota Técnica do IPEA, o estabelecimento de subsidio cruzado, contudo, deveria ser acompanhado do estabelecimento de cotas de diesel para empresas como ocorre para o ICMS, caso contrários poderia resultar em um incentivo; utilização de transportes movidos a combustível fóssil e desestimular a utilização de outros modais menos poluentes (CARVALHO et al, 2011, p.19-20)

${ }^{94} \mathrm{O}$ artigo $1^{\mathrm{o}}$ da Lei $\mathrm{n}^{\mathrm{o}}$ 10.336, de 19 de dezembro de 2001, reproduz o texto constitucional, in verbis:

Art. $1^{\underline{0}}$ Fica instituída a Contribuição de Intervenção no Domínio Econômico incidente sobre a importação e a comercialização de petróleo e seus derivados, gás natural e seus derivados, e álcool etílico combustível (Cide), a que se refere os arts. $\underline{149}$ e 177 da Constituição Federal, com a redação dada pela Emenda Constitucional $\underline{\mathrm{n}^{\circ} 33, \text { de } 11 \text { de dezembro de } 2001 .}$.

$\S 1^{\mathrm{o}} \mathrm{O}$ produto da arrecadação da Cide será destinada, na forma da lei orçamentária, ao:

I - pagamento de subsídios a preços ou transporte de álcool combustível, de gás natural e seus derivados e de derivados de petróleo;

II - financiamento de projetos ambientais relacionados com a indústria do petróleo e do gás; e

III - financiamento de programas de infra-estrutura de transportes. (grifou-se) 
considera que os recursos somente poderão ser aplicados em "programas" de infraestrutura dos transportes.

Segundo Ives Gandra, em razão da "natureza jurídica" do tributo, no caso a contribuição para intervenção do domínio econômico, este somente poderia ser destinado à finalidade específica, motivo pelo qual o financiamento da infraestrutura de transporte, de acordo com o referido tributarista, seria matéria do orçamento geral e a CIDE somente poderia ser aplicada em "programas" relacionados à infraestrutura. (GANDRA, 2008, p.698) $)^{95}$.

A interpretação do dispositivo apresentada por Gandra, profundamente influenciada pelo conceitualismo, mostra-se mais preocupada em revelar a "natureza jurídica"96 do tributo do que em analisar os aspectos práticos do uso dos recursos. De acordo com a crítica formulada por Castro e já mencionada anteriormente, o discurso jurídico brasileiro, preso às formas, não parece perceber o quanto estas se revelam insuficientes para a compreensão da realidade fática, ao mesmo tempo em que limitam o papel do direito como instrumento de promoção das liberdades. (CASTRO, 2012, p.218)

No caso da aplicação dos recursos da CIDE, este descompasso se mostra ainda mais evidente, conforme os alertas formulados por VASCONCELLOS et al (2011, p. 40) e já mencionados no capítulo 1 desta Dissertação. Segundo este autor, os recursos arrecadados com a Cide não são, na prática, investidos no setor de transporte em geral e tampouco no transporte coletivo urbano. Os recursos da CIDE são pulverizados entre os mais de cinco mil municípios brasileiros sem qualquer comprovação de que os mesmos estão sendo aplicados na infraestrutura de transporte, conforme foi reconhecido pelos Ministérios da Fazenda e das

\footnotetext{
${ }^{95}$ Nas palavras de Gandra: "se o objeto do financiamento e programas de infra-estrutura de transportes for o transporte em geral (de quaisquer produtos e até de pessoas), ainda que, indiretamente, possa alcançar o transporte de produtos do setor (petróleo, gás, álcool), ele não constituirá parte da área, salvo se ficar definida uma finalidade específica. O financiamento da infra-estrutura de transporte é matéria do orçamento geral, sendo próprio de impostos. Como a lei e a Constituição falam em financiamento de programas, é preciso ficar atento a que tais programas tenham o perfil de uma destinação específica. Do contrário, teremos imposto e não contribuição de intervenção no domínio econômico" (Gandra, 2008, p.698). (grife-se).

96 A interpretação de Ives Gandra tem como fundamento a jurisprudência firmada pelo Supremo Tribunal Federal a respeito da "natureza jurídica" dos tributos; segundo o tributarista, "a partir do julgamento do RE 146.733-9/S, no qual foi examinada a constitucionalidade da Lei no 7.689/88 que criou a Contribuição Social sobre o Lucro das pessoas jurídicas o relator do processo, Ministro Moreira Alves, enfrentou a questão relativa à natureza das contribuições, manifestando entendimento no sentido de que, com a Constituição Federal de 1988, a classificação dos tributos passou a ser a seguinte: impostos, taxas e contribuições de melhoria, referidas no art. 145, além de duas outras modalidades, para cuja instituição só a União é competente: o empréstimo compulsório e as contribuições sociais, inclusive as de intervenção no domínio econômico e de interesse de categorias e profissionais ou econômicas (arts. 148 e 149 )n - RTJ. 143:684. No mesmo sentido, o acórdão proferido no RE 148:754/RJ (RTJ, 150:888), dentre outros. (Gandra, 2008, p.669)
} 
Cidades na Portaria Interministerial $n^{\circ} 7 / 2006$, onde consta que "cerca de $7 \%$ dos recursos totais da CIDE são atribuídos ao transporte público". 97 (apud VASCONCELLOS et al, 2011, p.41)

Assim, conforme observa Vasconcellos et al (2011, p.40), os recursos da CIDE já são repassados aos municípios sem qualquer monitoramento acerca da observância da finalidade prevista em lei.

Desse modo, enquanto prevalece o entendimento pela vedação da aplicação de recursos no custeio das tarifas, os municípios utilizam os recursos oriundos da CIDE para custear outras despesas, mas não para tornar o valor das passagens mais condizentes com a prestação do serviço, sem onerar demasiadamente os usuários pagantes ${ }^{98}$.

Voltando à decisão proferida pelo STF no julgamento da ADI no 3.768-4, convém registrar que esta não se aprofundou na questão reativa a outras fontes de custeio além das tarifas; tampouco, na assunção do ônus da gratuidade do transporte de pessoas com mais de 65 anos com renda superior por usuários pagantes de renda inferior e menos ainda, na repartição dos custos da gratuidade em virtude da aplicação do princípio da solidariedade.

Ante o exposto, verifica-se que tanto a aplicação dos referencias da dogmática jurídica, presos aos aspectos formais, quanto o discurso do neoconstitucionalimo, voltado à aplicação de princípios apartados do contexto social, sem que ocorra em qualquer dos casos o aprofundamento acerca dos reflexos econômicos das medidas adotadas, embora possam, em tese, assegurar a fruição de determinado direito, no caso a gratuidade do transporte público urbano para usuários com mais de 65 anos, a despeito de sua renda; ao mesmo tempo, podem ter tornado mais longínqua a possibilidade prática de efetiva fruição desse direito por outra parcela significativa da população brasileira, que terá que arcar com os custos inerentes a este reconhecimento.

\footnotetext{
${ }^{97} \mathrm{O}$ governo federal zerou as alíquotas da CIDE por meio do Decreto $\mathrm{n}^{\mathrm{o}} 7.764 / 2012$. De acordo com Carvalho (2013, p.19), “[c]om a alíquota da CIDE atualmente zerada, não há mais espaço para essas deduções [PIS e COFINS] e abre-se mão de parcela importante da arrecadação (cerca de R\$ 43,21 bilhões entre 2004 e 2012). A definição da alíquota da CIDE com foco no controle de preços prejudica a adoção de subsídio cruzado entre combustíveis (e. g. redução do preço do diesel, que era subsidiado pela gasolina via outros instrumentos até 2001) e a realização de investimento em infraestrutura de transporte."

Recentemente, o Decreto $n^{\circ} 8395 / 2015$ restabeleceu a alíquota da CIDE em $\mathrm{R} \$ 100,00$ (cem Reais) por metro cúbico de gasolina e R $\$ 50,00$ (cinquenta Reais) por metro cúbico de óleo diesel.

98 Recentemente a Lei de mobilidade urbana 12.587/2012, em seu artigo $9^{\circ}$ estabeleceu que a tarifa de remuneração da prestação do serviço de transporte público coletivo será constituída pelo preço público cobrado somada a "outras" fontes de custeio, de modo a afastar a tarifa como fonte única de financiamento do sistema. A Lei n ${ }^{\circ} 12.587 / 2012$, contudo, não definiu o que seriam as "demais" fontes de financiamento.
} 
De toda sorte, ao enfraquecer o debate a respeito das questões de cunho econômico e político, ambas as abordagens (dogmática jurídica e neoconstitucionalismo) reduziram o papel do direito enquanto elemento estruturador da realidade social, reduzindo o espaço para reforma jurídica das políticas públicas subjacentes à fruição do direito focalizado, e fragilizando, por via de consequência, o próprio debate jurídico como também a efetividade dos direitos subjetivos. A necessidade de se incorporar o debate político e econômico ao debate jurídico será tratada no próximo capítulo. 


\section{A MOBILIDADE URBANA COMO PROBLEMA JURÍDICO- ECONÔMICO}

\subsection{Observações gerais}

Conforme já destacado no capítulo anterior, a dogmática jurídica e o neoconstitucionalismo têm afastado os aspectos político-econômicos do debate jurídico, no primeiro caso, por meio da adoção do discurso da suposta neutralidade da "forma" jurídica e, no segundo, ao supervalorizar o discurso moral abstrato. Em ambos os casos (dogmática e neoconstitucionalismo), o discurso jurídico padece da falta de contextualização e de pouco contato com a realidade social e econômica. A importância de se incorporar os aspectos econômicos ao debate jurídico sobre o conteúdo da constituição reside na possibilidade de tornar este último mais transparente e, deste modo, mais disponível para integrar a institucionalidade da democracia.

De acordo com David Kennedy (2013, p.8), os elementos da vida econômica: capital, trabalho, crédito e dinheiro são elementos não apenas da economia, mas também do direito. A norma jurídica não apenas regulamenta esses elementos, ela tem um papel na sua criação. Conforme sublinha KENNEDY (2013, p.8), a história da vida política e econômica é também a história das instituições e das normas jurídicas. O direito constitui os atores, insere-os na estrutura de relações em processo de estabilização e lhes fornece os limites para sua interação. A norma jurídica fornece, ainda, o discurso para o embate político e econômico. A análise da norma jurídica deve ser capaz de iluminar as mudanças econômicas e políticas que ocorrem no mundo e suas raízes no cotidiano da sociedade.

Assim, ao traçar os impactos das formas jurídicas sobre os atores políticos e econômicos, os juristas tornam-se capazes de identificar as escolhas entre as diferentes trajetórias da política e da economia. $\mathrm{O}$ entendimento do contexto no qual as normas foram criadas e dos propósitos aos quais se propunham servir possibilita aos juristas formularem não apenas um entendimento realista da norma e suas consequências, mas também propostas de reforma.

No caso da política de transporte, a análise descontextualizada da legislação e de aspectos constitucionais relacionados conduz ao fortalecimento de projetos que beneficiam determinados grupos de interesse sob o pretexto de serem os únicos caminhos possíveis para a 
efetivação de direitos subjetivos da população como um todo. De fato, a história da legislação de transporte no Brasil, conforme já ressaltado, está repleta de exemplos disso: a instalação de ferrovias ao estilo "cata-café" sem preocupação com o estabelecimento de redes de comunicação internas; a adoção do transporte rodoviário com o abandono de outros modais já estabelecidos, como forma de atender aos imediatismos do mercado; a adoção preferencial de veículos movidos por combustíveis fósseis, independentemente das externalidades produzidas por essas escolhas, etc. Em comum a todos esses casos, verifica-se a prevalência dos objetivos político-econômicos, cabendo à norma jurídica o papel instrumental de efetivação desses objetivos.

Além do mais, atualmente, é cediço que o exercício das liberdades individuais também pressupõe uma atuação por parte do Estado, visando protegê-las ou mesmo concretizá-las, o que tornou fútil a dicotomia entre direitos positivos e negativos, tão prezada pela dogmática jurídica ${ }^{99}$. Portanto, é a constatação de que a atuação estatal é necessária para a concretização dos direitos, mormente quando os custos para a implementação de determinadas políticas públicas são usados como justificativas para afastar sua implementação, que torna necessária a incorporação, pelo debate jurídico, dos aspectos econômicos relativos às políticas públicas. Por isso, ao excluir do debate jurídico aspectos econômicos relevantes de políticas públicas - como ocorre tanto sob o tratamento dogmático quanto sob a perspectiva neoconstitucionalista no Brasil - não estaremos protegendo a fruição dos direitos, mas fortalecendo a premissa de que as escolhas econômicas escapam à análise da sociedade por meio do discurso jurídico. É justamente porque sempre haverá consequências em termos de possibilidade de fruição de direitos pelos seus titulares, os cidadãos que integram a sociedade, que o jurista não deve se afastar ou se deixar excluir do debate, ou aceitar as restrições impostas por um discurso "abstrato" e formalista ou supostamente "neutro" advindo seja da economia como disciplina, seja de "formas" jurídicas abstratas e vazias da dogmática e do neoconstitucionalismo.

A complexidade do debate político, apontada por Posner (2010, p.117), como motivo de afastamento da sociedade que prefere delegar aos governantes o poder de escolha, também tem sido utilizada como escudo do debate econômico, o que, em última análise, favorece os grupos de interesse que tão bem dominam esse discurso.

\footnotetext{
${ }^{99}$ A dicotomia entre direitos negativos e positivos, conforme ressaltam Holmes e Sunstein, é baseada em uma confusão não apenas teórica, mas também empírica, de modo que a proteção das liberdades não se restringem à limitação do poder do estado, mas requerem uma atuação por parte deste Estado, visando a garantia desses direitos. (Holmes and Susntein,1999, p.36-48)
} 


\subsection{Da Análise Econômica do Direito}

A necessidade de que os aspectos econômicos do direito de ir e vir, subjacentes à mobilidade urbana, sejam considerados no debate jurídico, suscita outro questionamento: qual a abordagem deverá ser empregada?

A despeito da existência de diversas abordagens ${ }^{100}$, convém indicar as características principais e apontar eventuais críticas a respeito da Disciplina denominada Law and Economics, traduzida para a Língua Portuguesa como Direito e Economia ou Análise Econômica do Direito (AED). Tal escolha se justifica não apenas em razão da repercussão que a AED provocou no mundo jurídico a partir da década de sessenta do século $\mathrm{XX}$, mas também pelos objetivos desta dissertação, mais especificamente, a elaboração da análise da Política de Mobilidade Urbana e a apresentação de críticas e sugestões de reforma, utilizandose da metodologia da AJPE que, por sua vez, confronta-se com a AED de forma crítica.

De acordo com Bruno Salama (2008, p.5), a Análise Econômica do Direito consiste no corpo teórico fundado na aplicação da Economia às instituições jurídicas e políticas. Origina-se da Economia Política e do Realismo Jurídico estadunidense. A disciplina da Economia Política surge com Adam Smith no século XVIII e o Realismo Jurídico, nas faculdades norte-americanas na primeira metade do século XX, com o objetivo de estudar as leis e normas jurídicas como de fato elas funcionavam, ao invés de como previstas nos códigos, além de procurar a motivação dos entes e indivíduos na elaboração das mesmas. ${ }^{101}$

Salama $^{102}$ ressalta a existência de divergências com relação à classificação da AED como uma disciplina jurídica e indaga se esta corresponde a mais uma disciplina da Ciência Econômica. Dentre os autores mais destacados da literatura de "Direito e Economia", apontados por Salama (2008, p.6), estão Ronald Coase, Richard Posner, Guido Calabresi e Henry Manne.

Conforme observa CASTRO (2012, p.207), a AED surgiu como uma reação contrária às políticas redistributivas (que foram reforçadas nos Estados Unidos a partir da

\footnotetext{
100 Salama (2008, p.5) destaca a Escola de Chicago, Escola de New Haven, Escola Austríaca, Escola Institucionalista, Escola Neo-institucionalista e vertentes, que segundo Salama não configuram propriamente "escolas", são elas: Economia e Desenvolvimento, Teoria dos Jogos aplicada ao Direito, Direito e Economia Comparado, Direito e Economia Experimental, Direito e Economia Comportamental.

101 De acordo com Mercuro \& Mederma (2006, p.92 ), as raízes da AED encontram-se em Adam Smith e Jeremy Benthan.

${ }^{102}$ Cf. SALAMA $(2008$, p.11)
} 
década de 1960 como resultado do movimento em prol dos direitos civis) e também como alternativa ao fortalecimento, nas faculdades de direito, das ideias que defendiam uma articulação mais efetiva das "formas" jurídicas com os interesses de grupos sociais desfavorecidos do ponto de vista social e econômico. Posner, através de seu livro Economics Analysis of Law, de certo modo, "codificou" essa abordagem (AED) ao pregar a adoção de pressupostos da microeconomia como parte do processo de determinação das formas jurídicas e base da análise de questões jurídicas.

Apesar de Posner ter sido identificado como o grande expoente da AED, os seus referenciais analíticos vieram de Ronald Coase, cujas concepções acerca da interrelação entre Direito e Economia, que remontavam a década de 1930, foram ignoradas pelo debate acadêmico por muitos anos. (cf. CASTRO, 2012, p. 207)

De acordo com Mercuro \& Mederma (2006, p.103-104), a AED apresenta as seguintes premissas: (i) os indivíduos são racionais e por isso procuram maximizar sua satisfação em seu comportamento tanto em relação ao mercado, quanto nas relações "fora" do mercado (non-market behaviour); (ii) os indivíduos respondem a incentivos e (iii) as normas jurídicas devem servir de base para garantir a eficiência.

As premissas supramencionadas revelam a confiança que a AED deposita no "mercado" abstratamente concebido. Em razão desta confiança, as decisões dos juízes devem promover a "eficiência" que se supõe ínsita às ações empreendidas mediante a participação no mercado, pois deste modo será garantida a satisfação da sociedade. A AED, portanto, substituiu o indivíduo "razoável", das teorias tradicionais do direito, pelo indivíduo "racional" da Ciência Econômica. (MERCURO \& MEDERMA, 2006, p.11)

Neste sentido, colaciona-se o exemplo oferecido por Ronald Coase (1960, p. 8-9) a respeito da flexibilização de direitos, no caso o direito à propriedade, que o autor propõe com base na análise do caso Sturges v. Bridgman. Nesta ação judicial, uma confecção usava dois almofarizes, uma deles em operação a mais de 26 anos. Um médico adquiriu um imóvel próximo à confecção e na época não sofria nenhum dano. Oito anos após a aquisição, o médico construiu um consultório, próximo à cozinha da confecção. $\mathrm{O}$ barulho e a vibração vindos da cozinha impossibilitavam o atendimento dos pacientes no recém-construído consultório. Em virtude disso, o médico ajuizou uma ação visando impedir a confecção de usar seu maquinário. Ao final, a corte decidiu que o médico tinha direito de impedir o uso de maquinário. Coase sustenta que outro entendimento seria possível caso tivesse ocorrido uma negociação entre as partes. Na hipótese aventada por Coase, o médico permitiria o uso do 
maquinário se a confecção estivesse disposta a lhe pagar uma quantia suficiente para cobrir os prejuízos advindos da perda de pacientes decorrente da incapacidade de usar o consultório. A solução do problema acerca da continuidade do uso do maquinário residiria no fato de tal uso ser mais lucrativo para a confecção do que a renda que poderia ser suprimida do médico. Na segunda hipótese de decisão apresentada por Coase, o resultado prolatado pela corte teria sido diferente e a pretensão do médico teria sido indeferida. Neste caso, a confecção continuaria operando, sem pagar nada ao médico. Supondo que a renda do médico fosse reduzida pela continuidade das atividades da confecção, caberia ao médico pagar para que as atividades da confecção fossem encerradas. Ao final, Coase critica o fato da maioria das decisões judiciais não considerarem a hipótese de transação entre as partes, mesmo quando elas excedem o ganho obtido pelo exercício de um direito.

A abordagem da AED, encorajada por Coase e praticada pela Escola de Chicago, apresentava-se em oposição às ideias de Arthur Cecil Pigou, expoente da chamada "economia do bem-estar" (welfare economics). Pigou apoiava a introdução de impostos como meio de desencorajar ações econômicas que provocassem, mesmo que de modo involuntário, danos à sociedade. Um dos exemplos apresentados por Pigou dizia respeito à cobrança de um imposto compensatório a ser pago por companhias ferroviárias que causassem incêndios em florestas adjacentes às linhas férreas, decorrentes da produção de fagulhas provocadas pela passagem dos trens sobre os trilhos.

Coase defendeu que, ao invés da cobrança de impostos compensatórios em razão do dano, seria preferível empregar o conceito de custo de oportunidade ${ }^{103}$, por meio da comparação entre o valor do produto gerado pelos fatores de produção em relação aos danos provocados por aqueles. Destarte, para Coase, uma ação econômica capaz de causar prejuízos a terceiros poderia ser admitida, sendo que, nestes casos, os prejuízos deveriam ser considerados como parte integrante dos "custos" econômicos do investimento. Assim, as condutas causadoras de malefícios, caracterizáveis como "ofensas a um direito subjetivo", poderiam ser justificáveis econômica e juridicamente. Nas palavras de Castro (2012, p. 209):

[para] os adeptos da AED ao estilo de Chicago, as condutas vistas como injuriosas sob o prisma jurídico convencional passam a ser consideradas como juridicamente válidas, se forem economicamente justificáveis. O exemplo já referido deixa esse

\footnotetext{
$103 \mathrm{O}$ custo de oportunidade pode ser entendido como a perda que se tem ao se escolher um bem em detrimento de outro. De acordo com Mankiw, os economistas presumem que as pessoas são racionais, de modo que ao decidir por determinada escolha, elas vão considerar os resultados obtidos em relação aos custos. ( MANKIW, 2009, p. 52)
} 
ponto claro: o trem que emite fagulhas ao trafegar sobre a ferrovia passaria a ter, entre os 'custos' lícitos de sua operação, as florestas incendiadas.

Deste modo, pode-se dizer que, de um modo geral, a AED propõe a substituição da eficiência de Pigou pela de Pareto ${ }^{104}$ e pelo critério de Kaldor-Hicks. ${ }^{105}$ A "melhor"106 escolha, para a AED, portanto, seria aquela que de modo racional contribuísse para o aumento da riqueza da sociedade como um todo, conforme pressuposto da Economia Política segundo o qual ao fazer o bem para si o comerciante estará necessariamente fazendo um bem para toda a sociedade (SMITH, 1996).

Entre os custos do investimento, consoante preconiza Posner (2010), a decisão judicial deveria considerar como sendo custos lícitos até mesmo os custos que (com base em pressupostos convencionais) sejam eventualmente reputados 'maléficos', caso a atividade econômica ensejadora destes custos "maléficos" contribuam para o aumento de riquezas existentes na sociedade, em razão do custo-benefício apresentado.

O tipo de raciocínio defendido pela AED tem se replicado para muitas finalidades, inclusive para determinar conteúdos regulatórios de atividades econômicas nas democracias contemporâneas. Conforme observa Castro: (2012, p. 209)

[a análise de custo-benefício tem] motivado inúmeras iniciativas na área de regulação, inclusive a criação de metodologia de avaliação administrativa de políticas públicas, tais como a famosa (e controvertida) Ordem Executiva n. 12291,

\footnotetext{
104 A Eficiência de Pareto é explicada por Salama (2008, p.24) nos seguintes termos: "Dada uma gama de possíveis alocações de benefícios ou renda, uma alteração que possa melhorar a situação de pelo menos um indivíduo, sem piorar a situação de nenhum outro indivíduo, é chamado de 'melhora de Pareto'. Uma alocação será ótima no sentido de Pareto quando não for possível realizar novas melhoras de Pareto.

Dessa perspectiva, uma situação será eficiente se, e somente se, nenhum indivíduo puder melhorar sua situação sem fazer com que pelo menos um indivíduo piore a sua"

O "ótimo" de Pareto, portanto, consiste em buscar a melhora de um indivíduo e evitar a piora de outro. Ainda segundo Salama (2008, p.24) o "ótimo de Pareto" possibilitaria a concentração dos " recursos da sociedade em um único agente", impossibilitando, muitas vezes, as mudanças legislativas, posto que estas seriam afastadas sempre que correspondesse a supressão de recursos de um grupo em beneficio de outro.

105 De acordo com Salama (2008, p.24), o "ótimo de Pareto se completa com uma outra noção, o chamado critério (ou compensação) de Kaldor-Hicks. Suponha que uma mudança qualquer (por exemplo, a edição de uma nova lei) beneficie um determinado grupo de indivíduos ('os ganhadores'), mas prejudique outro grupo ('os perdedores'). Pelo critério de Pareto, tal mudança não poderia jamais ser eficiente (afinal há 'perdedores', isto é, indivíduos que pioram sua situação com mudanças.) Assim, por este critério, qualquer norma que estabeleça um privilégio, por mais nefasto que seja, jamais poderia ser alterada (afinal, o detentor deste privilégio sairia prejudicado pela mudança legislativa, mesmo que ela beneficiasse toda a sociedade) [...] O critério de KaldrorHicks busca superar a restrição imposta pelo ótimo de Pareto de que mudanças somente são eficientes e nenhum indivíduo fica em posição pior. Pelo critério de Kaldor-Hicks, o importante é que os ganhadores possam compensar os perdedores, mesmo que efetivamente não o façam. [...]”
}

106 Posner rejeita o entendimento de Dworkin a respeito da única escolha possível (POSNER, 2010, p. 263) 
adotada em 1981 pelo presidente Ronald Reagan (1911-2004), e a chamada 'Analise de Impacto Regulatório', propagada pela Organização para a Cooperação e Desenvolvimento Econômico e pelo Banco Mundial.

Deve-se observar que, no caso do influente trabalho de Posner (2010), a adoção de custos provenientes de ações controvertidas como sendo custos "lícitos", contudo, logo se revelou insustentável, levando o autor a uma postura que ele mesmo chamou de "pragmatismo", com o objetivo de relativizar a estratégia de submeter a análise jurídica aos conceitos da microeconomia. Posner passou então a sustentar que o pragmatismo, conforme ele defende, tem por objetivo a tomada de decisões ponderando as consequências das mesmas. (CASTRO, 2012)

Segundo Posner (2010, p.47), a adjudicação "pragmática" não é, como seus detratores acusam, sinônimo de tomada de decisão ad hoc, isto é, sempre decidir um caso de forma que tenha as melhores consequências imediatas sem considerar possíveis consequências futuras. De acordo com o referido autor, tal abordagem seria não pragmática ao desconsiderar as consequências sistêmicas adversas da adjudicação ad hoc.

De acordo com Castro (2012), a orientação de Posner ao abraçar a postura do "pragmatismo" não é convincente e constitui, ao que tudo indica, uma postura escapista diante de críticas, para as quais a lucratividade de um investimento não deve ser o critério definitivo de sua capacidade de gerar benefícios para a sociedade.

Destarte, a metodologia da AED pretende investigar as causas e consequências das regras jurídicas visando prever o comportamento dos cidadãos e agentes públicos diante de determinada regra; além disso, AED busca estabelecer os custos e benefícios resultantes da aplicação de determinados incentivos, considerando que as escolhas são fruto de uma decisão racional do agente que busca maximizar seu bem estar e reduzir seus prejuízos, considerando, principalmente, os pressupostos conceituais da Economia Neoclássica (GICO JR. In. TIMM, 2012, p.19)

Neste apanhado a respeito da AED, considerando os elementos apontados por Posner e Coase, destacam-se os seguintes pressupostos: a importância da análise a respeito do custobenefício como fundamento para a implementação de uma política pública ou para o reconhecimento de um direito; a submissão do direito aos conceitos da Economia Neoclássica e, portanto, a uma noção abstrata de "mercado"; a interdisciplinariedade e também o pragmatismo. 
A seguir, serão apresentados os pressupostos da AJPE, bem como as criticas formuladas por essa abordagem acerca dos elementos supramencionados.

\subsection{Da Análise Jurídica da Política Econômica}

As linhas gerais da Análise Jurídica da Política Econômica (AJPE) podem ser encontradas em Castro (2009), Castro (2012) e Castro (2014). Trata-se de abordagem jurídica a respeito da política econômica que rejeita tanto a concepção do Direito Econômico, decorrente da construção da dogmática das formas de intervenção do Estado no domínio econômico, quanto à concepção correspondente às elaborações da AED (CASTRO, 2009, p.6). Conexões entre a AJPE e o Direito Constitucional estão em Castro (2014 a).

O autor destaca a importância da interdisciplinaridade como instrumento para melhor compreensão das relações sociais e suas motivações materiais e imateriais (valores não econômicos). A AJPE defende o diálogo do direito com diversos campos da elaboração intelectual, acolhendo contribuições conceituais e metodológicas de várias disciplinas, em especial da Economia, embora não restrita à denominada "economia neoclássica", mas também a Antropologia Econômica, a Ciência Política, Sociologia Política, a Sociologia Econômica, a Teoria das Relações Internacionais e o Direito Econômico Internacional. A interdisciplinaridade deve auxiliar na abordagem e problematização das relações entre interesses materiais e valores não econômicos, além da percepção dos contextos empíricos onde as ditas relações se estabeleceram. (CASTRO, 2009, p. 8-9)

De acordo com a AJPE, a moeda não é uma entidade "neutra", associada apenas às funções de troca e "reserva de valor", mas sim uma "instituição social complexa", pois contém, além do valor quantificável atribuível a bens e serviços, também significados culturais, estéticos, religiosos, etc. Embora permaneça indissociável da política monetária, em sentido amplo, o emprego da moeda recebe influências da atividade financeira privada e de contratos não inteiramente alcançados pela normas de interesse público. Portanto, além de 
viabilizar a coordenação de interesses para fins econômicos, a moeda, na visão da AJPE, também está envolvida por significados não econômicos. ${ }^{107}$

Outro pressuposto da AJPE diz respeito à sua visão da economia, que é concebida como sendo formada por "redes de contratos" ou, conforme denominado por Castro, por agregados contratuais, ou ainda, por conjuntos de portfólios. Os agregados contratuais ou portfólios e suas interrelações abrangem não apenas os elementos da economia real e da economia monetária, mas também as articulações entre elas. Os contratos são formados por conteúdos de utilidade (que formam a "cláusula de utilidade") e conteúdos monetários (correspondentes ao que a AJPE designa por "cláusula monetária”). Os conteúdo contratuais de utilidade dizem respeito à utilidade do contrato no plano da economia real, aquilo que se busca obter materialmente com a sua execução. Já os conteúdos monetários, dizem respeito ao preço atribuído à utilidade adquirida, mas abrangem também obrigações monetárias de interesse público, tais como tributos e a taxa de juros básico da economia.

A AJPE distingue ainda entre os contratos financeiros e os não-financeiros. A diferença entre eles é que nos primeiros a cláusula de utilidade corresponde a uma prestação pecuniária ou obrigação financeira.

De acordo com a AJPE, embora a economia de mercado seja formada por agregados contratuais ou portfólios, cujos contratos são pactuados, em princípio, livremente, as relações econômicas permanecem submetidas ao jogo político democrático, fruto dos processos legislativo, administrativo e judicial traduzindo-se frequentemente como verdadeiros "conteúdos de interesse público" inseridos nos contratos privados. Os conteúdos de interesse público não estão sujeitos à livre negociação entre as partes, id. est., não podem ser negociados privadamente. Assim sendo, sua modificação depende de alterações promovidas por meio de processos dos quais a ordem jurídica exige ampla publicidade, como ocorre tipicamente com os processos legislativo, judicial e administrativo.

A análise de agregados contratuais pela AJPE permite a inclusão dos aspectos das políticas públicas na análise jurídica, contornando, assim, as dificuldades em se determinar o que se refere a "direitos subjetivos" de indivíduos e grupos daquilo que, para o administrador, constitui elemento técnico de uma política pública.

\footnotetext{
${ }^{107}$ Para melhor compreensão deste pressuposto, apresenta-se o exemplo colhido nos estudos da Antropologia Econômica acerca do valor simbólico atribuído à moeda por diversas sociedades, como praticado pelos habitantes das Ilhas Fiji que "bebem" dinheiro como meio de obter dádivas dos deuses. (CASTRO, 2009, p. 28)
} 
Ao analisar as políticas públicas, a AJPE distingue, sob o aspecto formal, os “contratos administrativos" e os "pactos sociais", estes últimos considerados, para fins de análise jurídica, como constitutivos de expectativas relevantes para os membros da sociedade a respeito do entendimento de "bem", "justiça" e "direito". Os pactos sociais são tratados como "contratos" especiais, em que os governos democráticos escolhidos pela sociedade indicam no momento eleitoral o que deve se tornar referência para reformas de políticas públicas. Os contratos administrativos - como, por exemplo, os contratos de concessão, de compra, de execução de obras - são considerados contratos formais, ao passo que os pactos sociais correspondem à relação estabelecida entre cidadãos e governos que constroem expectativas, tendo ademais incidência sobre a regulação dos contratos.

Castro (2009, p.37) ressalta a importância da percepção dos pactos sociais na análise da política econômica nos seguintes termos;

\begin{abstract}
A percepção a respeito dos pactos sociais é importante para fins de análise jurídica da política econômica, pois a consideração deles permite vislumbrar que a fruição de direitos privados (por exemplo, a propriedade predial urbana) inclui o recebimento de prestações estatais (por exemplo, o planejamento urbano) por parte do titular. Tais prestações são vistas como derivadas de 'pactos sociais', não de contratos formais. Os pactos sociais são considerados, nesse sentido, como variantes de contratos, ou balizamentos políticos deles, e assim, integram as redes ou agregados contratuais que organizam a economia.
\end{abstract}

Do ponto de vista da organização da economia, a AJPE considera importante distinguir quais direitos encontram-se abrangidos na órbita do consumo e quais se relacionam mais à produção e à troca comercial. Os direitos classificados como de produção têm como foco a troca econômica e a produção de bens e serviços (destinados à troca comercial), diferentemente dos direitos de consumo. Estes últimos são considerados sustentáculos jurídicos de "práticas que adquirem significado (cultural, moral, religioso, etc.) a partir de atividades mediante as quais os atores expendem - e não se engajam intencionalmente na produção ou troca comercial de - produtos e serviços”. (CASTRO, 2014, p. 44). Em ambas as espécies devem ser considerados não apenas os direitos individuais, mas também aqueles relacionados aos grupos sociais. (CASTRO, 2009, p.49-50).

De acordo com Castro (2009, p.51-52), a economia de mercado deve buscar a coordenação entre os aspectos da produção e do consumo visando garantir a fruição dos 
direitos e afastar os "exageros" que por ventura possam surgir na proteção dada a determinados direitos em detrimento dos outros. ${ }^{108}$

Neste sentido, pensando-se no caso da política das tarifas de transporte público, deve ela coordenar, de forma transparente, os aspectos do "direito de produção"109 voltados para o concessionário (custos e lucros) e os aspectos de consumo voltados para os usuários cuja pretensão consiste em pagar uma quantia módica em troca de um serviço de boa qualidade.

Os procedimentos analíticos da AJPE serão abordados no próximo item da dissertação. Antes, contudo, cumpre registrar, uma breve síntese das críticas formuladas pela AJPE a respeito da AED.

Embora tanto a AED quanto a AJPE tenham em comum a abertura para interdisciplinaridade e a importância atribuída a elementos empíricos, cumpre ressaltar que a AED considera como elemento decisivo para o estabelecimento de determinada política pública o custo-benefício resultante da mesma, ao passo que a AJPE elenca como prioridade a verificação da fruição dos diretos humanos e fundamentais. Nesse sentido, para a AJPE, as cartas de direito e declarações internacionais de direitos humanos "cumprem uma função 'dêitica' - valem como indicações de condensações discursivas que sinalizam áreas de preocupação de muitas autoridades e parcelas importantes da opinião pública local e global e representam um convite à ação institucional criativa e construtiva". 110

Ressalte-se que a análise de custo-benefício tal como aplicada pela AED tem como fundamento as lições da filosofia utilitarista, da economia neoclássica e da concepção desta

\footnotetext{
108 Nas palavras de Castro (2012, p.51), "A ênfase na proteção aos direitos de produção pode ser exagerada e redundar no aprofundamento da injustiça social. Contudo, a proteção dada ao consumo, impulsionada por idealismos em prol da justiça social, pode também ser exagerada e [...] comprometer definitivamente a capacidade de uma sociedade promover a produção competitiva. No limite, sendo suprimida propriedade comercial (essa foi a opção do socialismo real), destrói-se a economia de mercado e a dinâmica transformativa que lhe é inerente."

109 De acordo com Marcus Faro de Castro (2009, p.49-50), “[...] a AJPE considera importante distinguir, dentre os direitos fundamentais e os direitos humanos, os que, de um lado, do ponto de vista da organização da economia, se relacionam mais à produção, e, de outro, os que estão na órbita do consumo. Isso permite classificar os chamados 'direitos sociais, econômicos e culturais' (DESC) genericamente como 'direitos de consumo’ não importando se forem aplicados ao consumo de um indivíduos ou de um grupo. Outros direitos (exemplarmente, o direito de propriedade e a liberdade de contratar) são vistos como centralmente implicados nas esferas de produção e de troca econômica. Estes, portanto, são classificados genericamente como 'direitos de produção"”.

Importante registrar que a respeito da propriedade, Castro diferencia a propriedade comercial (ligada ao direto de produção), da propriedade civil (ligada ao direito de consumo).Como exemplo, o referido autor indica que "[u]m pacote de arroz na prateleira de um supermercado ou na despenda de um restaurante é propriedade comercial; porém o mesmo pacote no armário de minha cozinha 'transforma-se' em propriedade civil'." (grifos do autor)

${ }^{110}$ Castro (2014a, p. 715).
} 
última a respeito do "mercado" como resultado de um processo econômico apartado do aspecto político. Embora a AJPE não se negue a dialogar com os conceitos da economia neoclássica, não restringe sua análise a tal modelo, visto que considera o mercado não como uma noção "abstrata" cujas leis econômicas sempre serão seguidas, independentemente do contexto jurídico, cultural, político, religioso e social. Ao contrário disso, para a AJPE, os mercados são realidades empíricas contextualizadas em estruturas institucionais distintas, em grande parte dadas pelas redes contatuais sobre cuja estruturação e modificação dinâmica têm influência os pactos sociais. É porque entende o mercado como fruto, não apenas das leis econômicas, mas também de valores culturais, morais, políticos e sociais, ${ }^{111}$ que a AJPE define a moeda como uma instituição complexa, cujas funções vão além da troca e da reserva de valor estipuladas pelo mercado.

A AJPE, por outro lado, rejeita a visão pragmática do direito, nos moldes escapistas apresentados por Posner, ao mesmo tempo em que defende a necessidade de se considerar não apenas os aspectos econômicos, mas também os valores não-econômicos envolvidos na promoção de determinada política pública.

Cumpre esclarecer que a AJPE reconhece a necessidade de se considerar as consequências da adoção de determinada política pública não de forma isolada, mas inserida em um contexto social, razão pela qual defende uma visão consequencialista do direito, ressaltando a importância da análise jurídica como elemento de transformação social, de modo que as decisões devem ser consideradas não apenas em seus efeitos imediatos, mas também em razão das consequências mediatas provocadas pelas escolhas.

A seguir, critérios e procedimentos analíticos da AJPE serão empregados na tarefa de explicitar como conteúdos do direito de ir e vir, subjacente à mobilidade urbana, poder ser reformados. Não se trata de avançar uma proposta que deriva de "uma única resposta certa", mas de um exercício de análise jurídica que visa ilustrar como os desafios da reforma das

\footnotetext{
${ }^{111}$ Embora saliente a importância de estruturas institucionais e outros elementos valorativos, a AJPE contrasta com o chamado "neoconstitutionalismo" econômico conforme defendido por Douglass North. Para este autor e seus colaboradores, as instituições são relevantes apenas enquanto elementos promotores da ação maximizadora de utilidades. Cf. Lang (2013, p. 159-160). Em contraste com isso, para a AJPE, valores não-econômicos podem orientar uma ação para resultados distintos do que seriam os da ação maximizadora de utilidades. Neste sentido, Castro (2005), com base em Karl Polanyi, registra: “[T] oda economia (...) repousa sobre um conjunto de relações que não se define apenas economicamente. Tal conjunto de relações, embora não seja fixo, é formado por pessoas e / ou coisas às quais os indivíduos destinam, em determinadas circunstâncias, uma consideração de tal modo especial que o valor delas não pode ser facilmente traduzido em um preço econômico, ou seja, em uma prestação pecuniária contratualmente estabelecida. Tal consideração especial que os indivíduos destinam a pessoas e coisas durante a sua vida prende-se a noções de honra, dignidade, decência, afetividade, auto-estima, reverência, etc."
} 
políticas públicas de mobilidade urbana no Brasil podem ser enfrentados, do ponto de vista do direito, incluindo o direito constitucional. 


\section{ESTRUTURA DA PESQUISA}

\subsection{Delimitação do contexto empírico: a escolha das regiões administrativas}

Preliminarmente, em respeito ao rigor técnico e jurídico, deve-se ressaltar que o desmembramento do Distrito Federal em municípios é medida vedada pelo art. 32 da Constituição Federal. Apesar de tal impedimento constitucional, as áreas urbanas localizadas fora do Plano Piloto sofreram processo de expansão desde a inauguração da capital, processo este que se acentuou consideravelmente nos últimos anos. Com vistas a tornar a administração mais eficiente, o Governo do Distrito Federal instituiu as Regiões Administrativas (RAs) por meio da descentralização administrativa, sem, contudo, lhes conferir a autonomia própria dos municípios.

A escolha das regiões administrativas objeto desta pesquisa teve por fundamento o histórico de ocupação. Enquanto a RA de Águas Claras foi planejada como área urbana ${ }^{112}$ desde seu início (semelhante ao próprio DF), a RA de Vicente Pires foi idealizada inicialmente como colônia agrícola ${ }^{113}$ e, posteriormente, sofreu processo de urbanização sem contar com o apoio do poder público (similar à maioria das regiões administrativas do Distrito Federal).

Tendo em vista o histórico da ocupação, seria de se esperar que os índices relativos à fruição empírica do direito à mobilidade urbana apresentassem diferenças significativas entre as R.A's. Os resultados obtidos serão analisados mais adiante, quando se poderá verificar se de fato a origem da ocupação urbana foi fator determinante para a fruição do direito na atualidade.

As pesquisas realizadas pela Companhia de Planejamento do Distrito Federal (CODEPLAN), tanto em Águas Claras quanto em Vicente Pires seguiram a metodologia já utilizada na Pesquisa Distrital por Amostra de Domicílios (PDAD) realizada em 2004 e 2011,

112 CODEPLAN, Pesquisa Distrital por Amostra de Domicílio (PDAD) - 2013 em Águas Claras. Disponível em<http://www.codeplan.df.gov.br/images/CODEPLAN/PDF/pesquisa_socioeconomica/pdad/2013/Aguas_Clar as2013-2014.pdf $>$ Acesso em 13 de dez. de 2014.

\footnotetext{
${ }^{113}$ CODEPLAN. Pesquisa Distrital por Amostra de Domicílio (PDAD) - 2013-2014 em Vicente Pires. Disponível em http://www.codeplan.df.gov.br/images/CODEPLAN/PDF/pesquisa_socioeconomica/pdad/2013/Vicente Pires2013-2014.pdf > Acesso em 13 de dez. de 2014.
} 
quando foram utilizados o Cadastro Nacional de Endereços para Fins Estatísticos (CNEFE) do Instituto Brasileiro de Geografia e Estatística (IBGE). ${ }^{114}$

Embora a ocupação de Águas Claras tenha sido inicialmente planejada como área urbana e a de Vicente Pires, não, a média de renda das populações em ambas as RAs não apresentam grandes disparidades. De acordo com a Pesquisa realizada pela CODEPLAN, a maioria da população em ambas as regiões apresentam renda entre 10 e 20 salários mínimos; no caso de Águas Claras, ${ }^{115}$ esse índice é de 38,39\% e de Vicente Pires, o índice é de 33,68\%. A Tabela $\mathrm{n}^{\mathrm{a}}$ 2, mostrada abaixo, contém dados sobre as classes de renda na Região Administrativa de Águas Claras, formada pelas sub-regiões de Águas Claras Vertical, Arniqueiras e Areal. Já a Tabela $n^{\circ} 3$, mostrada na sequência, registra os dados sobre classes sociais na Região Administrativa de Vicente Pires.

\section{Tabela n 2 - Classes de Renda - Distribuição dos domicílios ocupados, segundo as Classes de Renda Domiciliar}

\begin{tabular}{|l|c|c|c|c|c|c|c|c|}
\hline \multirow{2}{*}{$\begin{array}{c}\text { Classes de } \\
\text { Renda* }\end{array}$} & \multicolumn{2}{|c|}{ Águas Claras } & \multicolumn{2}{|c|}{$\begin{array}{c}\text { Águas Claras } \\
\text { Vertical }\end{array}$} & \multicolumn{2}{c|}{ Arniqueiras } & \multicolumn{2}{|c|}{ Areal } \\
\cline { 2 - 9 } & $\mathbf{N}^{\mathbf{0}}$ & $\mathbf{\%}$ & $\mathbf{N}^{\mathbf{0}}$ & $\mathbf{\%}$ & $\mathbf{N}^{\mathbf{0}}$ & $\%$ & $\mathbf{N}^{\mathbf{0}}$ & $\%$ \\
\hline Até 1 SM & 613 & 1,83 & 118 & 0,55 & 70 & 1,13 & 425 & 7,20 \\
\hline Mais de 1 a 2 & 1.479 & 4,41 & 158 & 0,74 & 489 & 7,91 & 833 & 14,12 \\
\hline
\end{tabular}

\footnotetext{
114 De acordo com a CODEPLAN, “ [...] A opção por esse cadastro se justifica pela possibilidade de aplicação de ferramentas de geoprocessamento no controle em pesquisas amostrais domiciliares e pela confiabilidade indiscutível do cadastro do IBGE. [...] Para garantir robustez nas amostras, foi definido o menor tamanho amostral $n=450$ domicílios, de forma análoga à do IBGE na definição das áreas de ponderação, mesmo que a fórmula estatística indique uma amostra suficiente menor. Em algumas RAs, a amostra suportará subdivisão, por exemplo, o setor Vale do Amanhecer, de Planaltina, poderá ser desagregado, pois sua amostra atende ao tamanho mínimo de 450 domicílios." Embora se refira à pesquisa de Aguas Claras, explicação idêntica foi registrada na PDAD de Vicente Pires 2013.” (PDAD, 2014, p.6). Disponível em<http://www.codeplan.df.gov.br/images/CODEPLAN/PDF/pesquisa_socioeconomica/pdad/2013/Aguas_Clar as2013-2014.pdf> Acesso em 13 de dez. de 2014.

Explicação idêntica para a escolha da metodologia foi consignada na pesquisa realizada em Vicente Pires. Disponível em http://www.codeplan.df.gov.br/images/CODEPLAN/PDF/pesquisa_socioeconomica/pdad/2013/Vicente Pires2013-2014.pdf > Acesso em 13 de dez. de 2014.

115 Conforme pode ser observado na Tabela $n^{\mathbf{0}} 3$, existem diferenças entre os percentuais relativos às classes sociais conforme o bairro, todavia, foi considerada nesta Dissertação a média indicada na primeira coluna.
} 


\begin{tabular}{|l|c|c|c|c|c|c|c|c|} 
Mais de 2 a 5 & 4.601 & 13,73 & 827 & 3,86 & 1.309 & 21,19 & 2.465 & 41,79 \\
\hline Mais de 5 a 10 & 6.647 & 19,84 & 3.900 & 18,20 & 1.710 & 27,68 & 1.037 & 17,58 \\
\hline$\underline{\text { Mais de 10 a 20 }}$ & $\underline{12.865}$ & $\underline{38,39}$ & $\underline{10.203}$ & $\underline{47,61}$ & $\underline{1.693}$ & $\underline{27,40}$ & $\underline{969}$ & $\underline{16,43}$ \\
\hline Mais de 20 & 7.302 & 21,79 & 6.224 & 29,04 & 908 & 14,69 & 170 & 2,88 \\
\hline Subtotal & 33.507 & 100 & 21.430 & 100 & 6.179 & 100 & 5.899 & 100 \\
\hline $\begin{array}{l}\text { Renda não } \\
\text { declarada }\end{array}$ & 5.855 & & 4.097 & & 925 & & 833 & \\
\hline Total & 39.362 & & 25.527 & & 7.104 & & 6.732 & \\
\hline
\end{tabular}

Fonte: CODEPLAN - PDAD 2013-2014 - Águas Claras

* - Renda em número de salários mínimos (SM).

Tabela no 3 - Classes de Renda. Distribuição dos domicílios ocupados, segundo as Classes de Renda Domiciliar

\begin{tabular}{|l|c|c|}
\hline $\begin{array}{l}\text { Vicente Pires - Distrito Federal - } \\
\text { 2013 Classes de Renda* }\end{array}$ & $\mathbf{N}^{\mathbf{0}}$ & $\%$ \\
\hline Até 1 SM & 312 & 1,84 \\
\hline Mais de 1 a 2 & 1.003 & 5,92 \\
\hline Mais de 2 a 5 & 3.478 & 20,53 \\
\hline & & \\
Mais de 5 a 10 & 4.236 & 25 \\
\hline & & \\
Mais de 10 a 20 & 5.707 & 33,68 \\
\hline Mais de 20 & 2.207 & 13,03 \\
\hline Subtotal & 16.943 & 100 \\
\hline Renda não declarada & 2.987 & \\
\hline Total & 19.930 & \\
\hline
\end{tabular}

Fonte: CODEPLAN - PDAD 2013-2014 - Vicente Pires

* Renda em número de salários mínimos (SM). 
A Região Administrativa (RA) de Águas Claras foi criada por meio da Lei Distrital $\mathrm{n}^{\circ}$ 3.153, de 06 de maio de 2003, publicada no Diário Oficial de 21 de maio de 2003, embora a criação do bairro de Águas Claras tenha sido prevista na Lei Distrital no 385/1992 que autorizou a implantação do referido bairro na Região Administrativa de Taguatinga - RA III. A Região Administrativa de Águas Claras, segundo a Companhia de Planejamento do Distrito Federal (CODEPLAN), engloba os setores de Águas Claras (Vertical), Areal e Arniqueiras, subsconstituída por Arniqueiras, Veredas da Cruz, Setor Veredas e Veredão. A população urbana estimada da referida RA é de 121.839 habitantes, de acordo com a pesquisa realizada pela CODEPLAN.

Águas Claras, de acordo com o sítio eletrônico mantido pela Administração Regional de referida RA, foi resultado de planejamento urbano similar ao que ocorreu no Plano Piloto do Distrito Federal, in verbis:

A criação de Águas Claras], deu-se pela necessidade de viabilizar o metrô como uma proposta racional de ocupação do solo e expansão ordenada de Brasília. Quando a cidade foi planejada pelo arquiteto e urbanista Paulo Zimbres buscou-se a mesma qualidade de vida do Plano Piloto, embora em outros moldes urbanísticos. [...] ${ }^{116}$

Segundo a CODEPLAN, a RA de Vicente Pires, criada por meio da Lei n 4.327/2009, conta com uma população estimada em 73.300 habitantes e surgiu como resultado do processo de expansão urbana experimentado em todo o Distrito Federal. O nome da RA tem sua origem na Colônia Agrícola Vicente Pires que foi criada visando à produção de hortifrutigranjeiros em razão da abundância da água e da terra fértil da região, ainda na década de 70 do século $\mathrm{XX}^{117}$.

Idealizada, incialmente, como cinturão verde, Vicente Pires apresenta atualmente uma zona urbana (informalmente denominada Setor Habitacional Vicente Pires), formada principalmente por condomínios horizontais. A urbanização, realizada sem planejamento pelo poder público, apresenta sérios riscos para região rica em mananciais. Dentre os riscos

\footnotetext{
${ }^{116}$ Disponível em < http://www.aguasclaras.df.gov.br/a-regiao/dados-gerais.html> Acesso em 19 jan. 2015

${ }^{117}$ Disponível em < http://www.codeplan.df.gov.br/images/CODEPLAN/PDF/pesquisa socioeconomica/pdad/2013/Vicente Pires2013-2014.pdf > Acesso em 13 de dez. de 2014.
} 
decorrentes de aterramentos, ressaltam-se a impermeabilização do solo e a alteração de sua dinâmica. (CARVALHO JÚNIOR, 2011, p.36-37)

De acordo com o relatório de projetos apresentados pelo Governo do Distrito Federal em 2013 (GDF, 2013, p. 133), a região de Vicente Pires seria de responsabilidade federal ${ }^{118}$, razão pela qual a ocupação nesse território seria irregular, o que dificultaria a construção de equipamentos públicos. Ao mesmo tempo em que afirma que a área é de responsabilidade federal, o referido documento informa que em março de 2013 foi publicado o Projeto de Urbanismo de Vicente Pires, aprovado pelo Conselho de Planejamento Territorial e Urbano do Distrito Federal (Codeplan/DF), com previsão de empreendimentos na área de transporte para a referida Região Administrativa.

4.2. Etapas da análise

Com fundamento nos pressupostos mencionados no capítulo 3, a AJPE adota um conjunto de procedimentos no tratamento das questões jurídicas relacionadas às políticas públicas e às politicas econômicas de modo a verificar se essas políticas atendem aos requisitos de "concretização" ou de promoção da "efetividade" de direitos fundamentais. Insta ressaltar que, para a AJPE, uma política econômica pode ser "eficiente" quando considerados apenas os interesses materiais subjacentes, resultando até mesmo em algum crescimento do Produto Interno Bruto (PIB), mas ao mesmo tempo ser considerada "injusta" por contrariar interesses morais, culturais, religiosos de determinado grupos reduzindo a "disposição para a cooperação livremente consentida." (CASTRO, 2009, p.37)

A AJPE indica as seguintes etapas de análise:

\footnotetext{
${ }^{118}$ De acordo com o Caderno das Cidades, "Atualmente, a região de Vicente Pires é de responsabilidade federal e qualquer ocupação nesse território é irregular, o que dificulta a instalação de equipamentos públicos. Em 22 de março deste ano, contudo, foi dado mais um passo rumo à solução do problema. O Projeto de Urbanismo de Vicente Pires foi aprovado pelo Conselho de Planejamento Territorial e Urbano do Distrito Federal (Conplan/DF)" (GDF, 2013, p.133). Disponível em http://www.transparencia.df.gov.br/Planejamento\%200ramento\%20\%20Relatrios\%20Gerenciais/caderno cidad es\%202013.pdf > acesso em 10 de dez. de 2014.
} 
O primeiro passo consiste na identificação de uma política pública, um componente de uma política ou uma proposta de reforma que suscitem controvérsia entre os interessados e a opinião pública nas democracias.

O segundo passo consiste em identificar qual(is) o(s) direito(s) fundamental(is) previsto(s) na Constituição, leis, tratados internacionais atingido(s) pela controvérsia.

Identificado o direito, o terceiro passo diz respeito à "decomposição analítica" do mesmo, ou seja, a identificação das prestações necessárias para que se possa caracterizar o efetivo gozo do direito.

Após a identificação dos elementos, passa-se a "quantificação", etapa que consiste em mensurar e atribuir peso aos elementos prestacionais. Nesta etapa, podem ser utilizados dados ou informações produzidos por autoridades, especialistas ou o pesquisador pode produzir dados novos.

O quinto passo consiste na reunião de todas as informações correspondentes aos componentes prestacionais quantificados com vistas à elaboração do "índice de fruição empírica" (IFE).

$\mathrm{Na}$ sexta etapa, com fundamento no índice supramencionado, o pesquisador realiza a análise jurídica da politica pública ou econômica visando à construção de um "padrão" utilizado para caracterizar, em termos quantitativos, a "efetividade empírica juridicamente validada do direito considerado". Trata-se do "Padrão de Validação Jurídica" (PVJ) ${ }^{119}$ A pesquisa pode, ainda, ter como finalidade demonstrar de modo objetivo as diferenças na implementação de determinada política pública em relação a populações de diferentes raças, classes sociais, cidades, estados, países, etc., o que pode revelar desigualdades entre experiências de fruição empírica de direitos subjetivos.

O uso de indicadores tem adquirido grande importância como meio de planejamento de politicas de governança global não apenas pelas agências internacionais, notadamente a Organização das Nações Unidas e pelo Banco Mundial, como também por grupos interessados em negócios e investimentos. Mas o que se entende por indicadores? De acordo com Davis et al(2011, p.3), indicadores são conjuntos de dados ordenados hierarquicamente com o propósito de representar determinado fenômeno social. ${ }^{120}$

\footnotetext{
119 Conforme esclarece Castro (2009, p.45), o pesquisador pode estar interessado em verificar a efetividade de um direito após a implementação de uma determinada política; neste caso, o PVJ estabelecerá a comparação entre a realidade anterior e posterior à implementação de determinada politica.

120 Davis define os indicadores nos seguintes termos: "An indicator is a named collection of rank-ordered data that purports to represent the past or projected performance of different units. The data are generated through a
} 
Embora o uso de indicadores não seja o único meio possível para representar os fenômenos sociais que podem também ser representados por textos, fotos, vídeos, etc, os indicadores suscitam a possibilidade de simplificação dos fenômenos sociais geralmente mais complexos do que a forma como são representados, o que possibilita aos formuladores de políticas públicas justificar a adoção de determinadas medidas em detrimento de outras, tomando como fundamento determinados indicadores. (DAVIS et al, 2011, p.11-12). Não obstante a produção e o uso de indicadores tenha o potencial de alterar as formas de exercício do poder, pouco se tem questionado como as condições nas quais foram produzidos os indicadores influenciam os processos de decisões baseados nos mesmos e como tais índices afetam a distribuição de poder e o planejamento das políticas públicas. (DAVIS et al, 2011,p.3-4)

Considerando a importância hodierna dos indicadores para a formulação das políticas públicas, a AJPE não se limita a apresentar os indicadores isoladamente, mas busca, de posse de tais informações, formular propostas de reforma das políticas públicas. Destarte, a etapa final da pesquisa, desenvolvida sob a perspectiva da AJPE, corresponde à recomendação de reforma da política pública subjacente ao exercício de um direito fundamental cuja efetividade tenha sido considerada insuficiente.

Dito isto, cumpre registrar os dados da pesquisa realizada, conforme a metodologia supramencionada. A pesquisa, realizada no âmbito desta dissertação para fins demonstrativos do emprego dos instrumentos analíticos e ideias da AJPE, consistiu na coleta de dados das regiões administrativas de Águas Claras e Vicente Pires, ambas no Distrito Federal, objetivando o estabelecimento de comparação entre as referidas regiões, por meio de critérios objetivos. Conforme já ressaltado acima, o exercício tem por finalidade, não produzir diagnósticos ou recomendações definitivas de reformas, mas exemplificar como o trabalho jurídico pode ser desenvolvido de maneira útil, com foco sobre fatos relevantes da experiência social, com vistas a dar efetividade à fruição de direitos fundamentais, sem marginalizar a importância da dimensão econômica das políticas públicas.

process that simplifies raw data about a complex social phenomenon. The data, in this simplified and processed form, are capable of being used to compare particular units of analysis (such as countries or institutions or corporations), synchronically or over time, and to evaluate their performance by reference to one or more standards."(DAVIS, 2011, p.7) Um indicador consiste em uma coleção de dados, ordenados de forma hierarquizada, referentes a eventos passados ou projetados para o futuro. Os dados são generalizações através de um processo que simplifica um fenômeno social complexo. Esta simplificação permite que sejam usados para comparar dados unitários de países, corporações ou organizações em um mesmo período ou ao longo do tempo com base em padrões estabelecidos.) 
4.3. A análise dos dados

Definidas as regiões administrativas, deve-se seguir os passos indicados pela metodologia da AJPE:

\section{A) Identificação da Política Pública}

A política pública se refere à politica de mobilidade urbana desenvolvida tendo em vista sua implementação nas Regiões Administrativas de Águas Claras e Vicente Pires.

\section{B) Identificação do Direito Fundamental correlato:}

O direito fundamental, cujo nível de fruição se busca verificar por meio da análise dos dados, se refere ao direito de ir e vir ou liberdade de locomoção/circulação, consignado no art. $5^{\circ}$, inciso XV, da Constituição Federal, in verbis:

\footnotetext{
Art. $5^{\circ}$ Todos são iguais perante a lei, sem distinção de qualquer natureza, garantindo-se aos brasileiros e aos estrangeiros residentes no País a inviolabilidade do direito à vida, à liberdade, à igualdade, à segurança e à propriedade, nos termos seguintes: [...]

$\mathrm{XV}$ - é livre a locomoção no território nacional em tempo de paz, podendo qualquer pessoa, nos termos da lei, nele entrar, permanecer ou dele sair com seus bens;
}

\section{C) Decomposição analítica do direito}

A decomposição analítica consiste na identificação das prestações necessárias à efetivação do direito de ir e vir no contexto acima delimitado. 
Compulsando a legislação referente à política pública em foco, é possível identificar alguns conteúdos de interesse público. Entre as leis relevantes para a identificação de tais conteúdos estão incluídas: a Lei de Mobilidade Urbana (Lei $n^{\circ} 12.587 / 2012$ ), a Lei de concessão e permissão de serviços públicos (Lei n ${ }^{\circ}$ 8.987/1995), Código de Trânsito Brasileiro (Lei $n^{\circ}$ 9.507/1997) e Leis distritais. De acordo com o art. 14, inciso I, da Lei $n^{\circ}$ 12.587/2012, os usuários do Sistema Nacional de Mobilidade Urbana têm o direito de receber serviços adequados nos termos do art. $6^{\circ}, \S 1^{\circ}$, da Lei $n^{\circ} 8.987 / 95$, que define o serviço público adequado como sendo aquele que satisfaz as condições de segurança, continuidade, regularidade, eficiência, segurança, atualidade, generalidade, cortesia na sua prestação e modicidade das tarifas.

A despeito da indicação nas leis dos conteúdos de segurança, modicidade das tarifas, atualidade do serviço, a legislação brasileira atual não traz definições objetivas e contextualizadas acerca do significado de tais conteúdos, o que facilita a subtração dos respectivos temas do âmbito do debate jurídico, sendo as discussões pertinentes, no mais das vezes, transferidas para a esfera politica, que frequentemente procura apoio em contribuições e avaliações de tecnocratas. Ao recomendar o estabelecimento critérios objetivos para a verificação da existência de tais conteúdos, atuando de forma interdisciplinar, a AJPE possibilita que o debate novamente seja em parte reabsorvido para o interior do campo jurídico.

Os conteúdos de interesse público, conforme já explicitado anteriormente, são elementos que escapam ao poder de negociação privada das partes e cuja alteração está submetida aos processos legislativo, administrativo ou judicial. Evidentemente, além dos conteúdos indicados nesta pesquisa, muitos outros poderiam ser apontados. Todavia, em virtude da dificuldade em se conseguir dados e tendo em conta, ainda, a necessidade de se delimitar o objetivo específico da pesquisa, serão considerados os aspectos apresentados abaixo da política de mobilidade urbana, correspondentes aos seguintes "elementos prestacionais":

(i) Segurança;

(ii) Prioridade para o transporte não motorizado;

(iii) Modicidade das Tarifas e

(iv) Diversidade de modais públicos. 
A seguir, serão oferecidos comentários gerais sobre cada um desses tipos de elementos prestacionais considerados na pesquisa da presente dissertação. Na sequência, será explicitada a quantificação constitutiva da fruição empírica do direito em questão nas duas RAs selecionadas.

Ref. (i) - Segurança

O direito à segurança nos deslocamentos das pessoas, correlato ao próprio direito à vida, foi consignada no art. $5^{\circ}$, inciso VI, da Lei de Mobilidade Urbana, do mesmo modo que o direito ao transporte seguro foi previsto no art. $6^{\circ}, \S 1^{\circ}$, da Lei $n^{\circ} 8.987 / 1995$. É importante observar, ainda, que o art. $1^{\circ}, \S 1^{\circ}$, da Lei $n^{\circ} 9.507 / 1997$ considera o trânsito, em condições seguras, como um direito de todos e dever dos órgãos e entidades componentes do Sistema Nacional de Trânsito, cabendo a esses adotar medidas destinadas a assegurar esse direito.

Com vistas a reduzir os acidentes de trânsito com vítimas fatais, a Organização das Nações Unidas (ONU), em Assembleia Geral realizada em 2 de março de 2010, por meio da Resolução A/64/L44, proclamou o período de 2011 a 2020 como a Década Mundial de Ações para a Segurança no Trânsito. O Brasil, signatário da Resolução por meio do Comitê Nacional de Mobilização para a Segurança e Paz no Trânsito, coordenado pelo DENATRAN/Ministério das Cidades, elaborou um plano nacional de redução de mortes e acidentes e lançou a Campanha PARADA - Pacto Nacional pela Redução de Acidentes, como objetivo de reduzir em $50 \%$ o número de mortes no trânsito. ${ }^{121}$

Tendo em vista os objetivos traçados pela ONU e pelas autoridades brasileiras de trânsito, colaciona-se a pesquisa sobre acidentes de trânsito com mortes realizada pelo Departamento de Trânsito do Distrito Federal (DETRAN-DF) nas vias urbanas das RAs de Águas Claras e Vicente Pires.

$\mathrm{Na}$ Tabela $\mathrm{n}^{\circ} 4$ abaixo estão registrados os dados de acidentes com mortes na Região Administrativa de Águas Claras e na Tabela ${ }^{\circ}$ 5, da Região Administrativa de Vicente Pires.

\footnotetext{
${ }^{121}$ Disponível em < http://www.brasil.gov.br/saude/2012/11/novo-site-da-campanha-parada-2013-um-pactopela-vida-ja-esta-no-ar > Acesso em 14 de jan. de 2014.
} 
Tabela no 4 - Acidentes de trânsito com morte, por via - R. A. Águas Claras

\begin{tabular}{|c|c|c|c|c|c|c|c|c|c|c|}
\hline & 2005 & 2006 & 2007 & 2008 & 2009 & 2010 & 2011 & 2012 & 2013 & $\begin{array}{c}2014 \\
\text { Até } \\
\text { dezem } \\
\text { bro }\end{array}$ \\
\hline $\begin{array}{c}\text { Total de } \\
\text { acidentes - } \\
\text { Águas } \\
\text { Claras }\end{array}$ & $\mathbf{2}$ & - & $\mathbf{3}$ & $\mathbf{3}$ & $\mathbf{4}$ & $\mathbf{3}$ & $\mathbf{5}$ & $\mathbf{1}$ & $\mathbf{2}$ & $\mathbf{2}$ \\
\hline $\begin{array}{c}\text { Av. Águas } \\
\text { Claras }\end{array}$ & - & - & 1 & - & 1 & - & 1 & - & - & - \\
\hline $\begin{array}{c}\text { Av. } \\
\text { Arniqueiras }\end{array}$ & - & - & - & - & - & - & 1 & - & - & - \\
\hline $\begin{array}{c}\text { Av. } \\
\text { Araucárias }\end{array}$ & 1 & - & - & 1 & - & - & 1 & - & - & - \\
\hline $\begin{array}{c}\text { Av. das } \\
\text { Castanheiras }\end{array}$ & - & - & - & - & 1 & - & - & - & - & 1 \\
\hline $\begin{array}{c}\text { Av. Parque } \\
\text { Aguas Claras }\end{array}$ & - & - & - & 1 & - & - & - & - & - & - \\
\hline $\begin{array}{c}\text { Av. Vereda } \\
\text { da Cruz }\end{array}$ & - & - & - & - & - & - & 2 & - & - & - \\
\hline $\begin{array}{c}\text { Via entre } \\
\text { ADE/SHA }\end{array}$ & - & - & - & - & - & - & - & - & 1 & 1 \\
\hline $\begin{array}{c}\text { Via interna }- \\
\text { colônia } \\
\text { agrícola } \\
\text { Arniqueiras }\end{array}$ & - & - & - & - & - & - & - & - & 1 & - \\
\hline $\begin{array}{c}\text { Via paralela a } \\
\text { DF 075 }\end{array}$ & - & - & - & - & - & - & - & 1 & - & - \\
\hline $\begin{array}{c}\text { Não } \\
\text { classificada }\end{array}$ & 1 & - & 2 & 1 & 2 & 3 & - & - & - & - \\
\hline
\end{tabular}

Fonte: GDF/SSP/DETRAN-DF/GEREST ${ }^{122}$

Nota: considera-se vitima fatal, quando o óbito ocorre até 30 dias após a data do acidente.

Tabela no 5 - Acidentes de trânsito com morte, por via - R. A. de Vicente Pires

\begin{tabular}{|l|c|c|c|c|c|c|c|c|c|c|}
\hline & 2005 & 2006 & 2007 & 2008 & 2009 & 2010 & 20122 & 2012 & 2013 & $\begin{array}{c}2014 \text { (até } \\
\text { dezembro) }\end{array}$ \\
\hline Total de & - & 1 & - & - & 1 & - & 1 & 5 & 2 & 2 \\
\hline
\end{tabular}

${ }^{122}$ Disponível em < http://www.detran.df.gov.br/o-detran/estatisticas-do-transito/acidentes.html $>$ Acesso em 20 de jan. de 2014. 


\begin{tabular}{|c|c|c|c|c|c|c|c|c|c|c|}
\hline $\begin{array}{l}\text { acidentes - } \\
\text { Vicente } \\
\text { Pires }\end{array}$ & & & & & & & & & & \\
\hline Rua 05 & - & - & - & - & - & - & 1 & 1 & - & - \\
\hline Rua 06 & - & - & - & - & - & - & - & 1 & - & - \\
\hline Rua 08 & - & - & - & - & 1 & - & - & 1 & 1 & - \\
\hline Rua 10 & - & 1 & - & - & - & - & - & 1 & 1 & - \\
\hline Rua 12 & - & - & - & - & - & - & - & 1 & - & - \\
\hline Rua 48 & - & - & - & - & - & - & - & - & - & 1 \\
\hline $\begin{array}{l}\text { Via interna } \\
\text { C. A. de } \\
\text { Vicente } \\
\text { Pires } \\
\end{array}$ & - & - & - & - & - & - & - & - & - & 1 \\
\hline
\end{tabular}

Fonte: GDF/SSP/DETRAN-DF/GEREST ${ }^{123}$

Nota: considera-se vitima fatal, quando o óbito ocorre até 30 dias após a data do acidente.

Considerando o número de acidentes com mortes e o número de habitantes em cada uma das regiões administrativas, foi elaborada a Tabela $\mathrm{n}^{\circ} 6$, que indica o número proporcional de acidentes com morte por habitantes.

Tabela $\mathbf{n}^{0} 6$ - Número de acidentes com morte x número de habitantes

\begin{tabular}{|c|c|c|c|}
\hline $\begin{array}{c}\text { Região } \\
\text { Administrativa }\end{array}$ & $\begin{array}{c}\text { Número de } \\
\text { Acidentes com } \\
\text { mortes } \\
(\mathbf{2 0 0 5 - 2 0 1 4 )}\end{array}$ & $\begin{array}{c}\text { Número de } \\
\text { habitantes (1) }\end{array}$ & $\begin{array}{c}\text { Percentual número } \\
\text { de } \\
\text { acidentes/habitantes }\end{array}$ \\
\hline Águas Claras & 25 & 121.839 & 0,02 \\
\hline Vicente Pires & 12 & 73.300 & 0,01 \\
\hline
\end{tabular}

Fonte: GDF/SSP/DETRAN-DF/GEREST

Fonte: CODEPLAN - PDAD 2013-2014 (1)

Ref. (ii) - Prioridade para o transporte não motorizado

A prioridade para o transporte não motorizado constitui uma das diretrizes da Política Nacional de Mobilidade Urbana fixada no art. $6^{\circ}$, inciso II, da Lei ${ }^{\circ} 12.587 / 2012$. Tal política

\footnotetext{
${ }^{123}$ Disponível em < http://www.detran.df.gov.br/o-detran/estatisticas-do-transito/acidentes.html $>$ Acesso em 20 de jan. de 2014.
} 
tem como objetivo a redução das externalidades (ambientais) provenientes dos transportes movidos por combustíveis fósseis, sendo, portando, um dos aspectos também do direito fundamental ao meio ambiente equilibrado previsto no art. 225 da Constituição Federal, que, na análise realizada, fica incorporado à experiência da fruição do direito de ir e vir.

Entre as externalidades ambientais geradas pelo transporte, uma das mais graves é a poluição ${ }^{124}$. A poluição atmosférica é resultado do "lançamento de gases e partículas sólidas na atmosfera, provenientes do processo de combustão do motor que usa combustíveis fósseis". (ANTP, 2012, parte I, p. 96).

Os veículos movidos a diesel são os maiores poluentes. No Brasil, esse combustível é permitido para uso de ônibus, caminhões e alguns utilitários. ${ }^{125}$

Objetivando reduzir a emissão de gases poluentes, o Código de Trânsito Brasileiro determinou, em seu art. 104, que todos os veículos motorizados fossem submetidos a inspeções cuja periodicidade seria estabelecida pelo CONTRAN, para os itens de segurança, e pelo Conselho Nacional do Meio Ambiente (CONAMA), para controle dos índices de emissão de gases poluentes e de ruídos. ${ }^{126}$ Neste mesmo diapasão, a Lei $n^{\circ} 8.723$, de 28 de outubro de 1993, estabeleceu a obrigação dos fabricantes de motores e veículos automotores de adotar providências visando reduzir os níveis de emissão de gases, enquadrando-se nos limites estabelecidos no texto legal.

Além de causar poluição atmosférica, o trânsito é responsável pela poluição sonora. A Organização para Cooperação e Desenvolvimento Econômico (OCDE) recomenda que o ruído do tráfego não exceda 65 decibéis. Infelizmente, as cidades brasileiras não realizam medições sistemáticas de ruídos, o que inviabiliza a coleta de dados. (ANTP, 2013, p.105).

\footnotetext{
${ }^{124}$ As preocupações com o meio ambiente também foram consignadas na Lei $\mathrm{n}^{\mathbf{0}}$ 12.187/2009 que instituiu a Politica Nacional sobre Mudança do Clima e o "compromisso nacional voluntário de redução das emissões de gases de efeito estufa" (art12). A referida lei foi regulamentada pelo Decreto $n^{0} 7.390 / 2010$.

125 A proibição do uso de diesel por automóveis foi consignada na Portaria no 23, de 6 de junho de 1994, editada pelo Departamento Nacional de Combustível (DNC), do Ministério de Minas e Energia.
}

126 De acordo com o artigo 104 do CTB, Art. 104. "Os veículos em circulação terão suas condições de segurança, de controle de emissão de gases poluentes e de ruído avaliadas mediante inspeção, que será obrigatória, na forma e periodicidade estabelecidas pelo CONTRAN para os itens de segurança e pelo CONAMA para emissão de gases poluentes e ruído.” 
Já a poluição de resíduos do sistema de transporte diz respeito ao descarte de pneus velhos $^{127}$, carcaças de veículos, óleo e lubrificantes usados que causam prejuízos aos solos e aos recursos naturais (lençóis freáticos) em razão da decomposição química de seus componentes (ANTP parte I, 2012, p. 106)

Além de gerar essas externalidades, o trânsito é responsável pela morte e acidentes que geram altos custos para a sociedade. Tendo em vista a relevância de tal elemento, este foi indicado no primeiro índice ( " $S$ ").

Em atenção às disposições contidas na Constituição Federal e na Política Nacional de Mobilidade Urbana, que prevê o incentivo ao transporte não motorizado ${ }^{128}$, o Distrito Federal editou a lei $\mathrm{n}^{\mathrm{o}} 3.639$, de 28 de julho de 2005 que dispôs dobre a implantação de ciclovias nas rodovias do Distrito Federal, cuja regulamentação seria feita pelos órgãos competentes. Em 2006, foi editada a Lei Distrital $\mathrm{n}^{\mathrm{o}} 3.885$ instituindo a política de mobilidade urbana cicloviária e de incentivo ao uso de bicicleta no DF. De acordo com o art. $2^{\circ}$ da referida lei, a politica de mobilidade urbana cicloviária deverá garantir a qualidade de vida nas cidades do DF, a implementação de infraestrutura cicloviária, constituída por ciclovias ${ }^{129}$, ciclofaixas $^{130}$, faixas compartilhadas, bicicletários, paraciclos, sinalização e similares, além da integração da bicicleta no sistema de transporte público existente.

$\mathrm{Na}$ Tabela $\mathrm{n}^{\mathrm{o}} 7$, adiante colacionada, foi registrada a extensão a malha cicloviária em várias áreas do Distrito Federal, considerando o processo de implementação divulgado pelo governo distrital.

\footnotetext{
127 Conforme dados divulgados pela Associação Nacional da Indústria de Pneus (ANIP), em 2011, foram comercializados no Brasil cerca de 67 milhões de pneus, a maioria cerca de 32 milhões para automóveis. Segundo cálculos da ANTP, se cada pneu ocupar $0,10 \mathrm{~m}^{3}$, seriam necessários 3,0 milhões de $\mathrm{m}^{3}$ para armazenalos todos os anos. Embora a ANTP reconheça que o programa iniciado em 1999 que determinou a utilização do resíduo na indústria de sapatos, pisos, borrachas, tenha suavizado o problema, grande parte dos pneus ainda são descartados na natureza. (ANTP, 2013, 165)

128 Algumas diretrizes da Política Nacional de Mobilidade Urbana apresentadas pelo Ministério das Cidades foram divulgadas antes da edição da própria Lei $\mathrm{n}^{\circ} 12.587 / 2012$ que trata do tema. (v. capítulo 1 desta dissertação)

129 Ciclovias são pistas isoladas das vias destinadas aos veículos motorizados, são dimensionadas para a circulação segregada de bicicletas. (ANTP, parte II, 2012, p.40)

${ }^{130}$ Ciclofaixas são "faixas exclusivas para bicicletas, implantadas em parte de pistas existentes do sistema viário das cidades e dimensionadas para a circulação segura de bicicletas.” (ANTP, 2parte II, 2012, p.41)
} 
Tabela n 7 - Extensão das Ciclovias no Distrito Federal

\begin{tabular}{|c|c|c|c|c|}
\hline LOCAL & \multicolumn{2}{|l|}{ ESTÁGIO } & VALOR (R\$) & \begin{tabular}{|l} 
EXTENSÃO \\
$(\mathrm{m})$
\end{tabular} \\
\hline $\begin{array}{l}\text { Asa Sul - Lote } 2 \\
\text { (L2) }\end{array}$ & $\begin{array}{l}\text { Em } \\
\text { andamento }\end{array}$ & $97 \%$ & $6.500 .072,71$ & $16.724,01$ \\
\hline UNB - Lote 7 & \begin{tabular}{|l} 
Em \\
andamento
\end{tabular} & $95 \%$ & $3.476 .965,05$ & $12.003,50$ \\
\hline Guará & $\begin{array}{l}\text { Em } \\
\text { andamento }\end{array}$ & $90 \%$ & $1.118 .728,37$ & $5.768,61$ \\
\hline $\begin{array}{l}\text { Asa Norte -lote } 4 \text { - } \\
\text { (W4) }\end{array}$ & $\begin{array}{l}\text { Em } \\
\text { andamento }\end{array}$ & $68 \%$ & $6.063 .812,74$ & $18.507,45$ \\
\hline Gama Lote 1 - & $\begin{array}{l}\text { Em } \\
\text { andamento }\end{array}$ & $91 \%$ & $1.954 .023,71$ & $11.582,56$ \\
\hline Gama Lote 2 - & $\begin{array}{l}\text { Em } \\
\text { andamento }\end{array}$ & $74 \%$ & 2.222.906,56 & $13.448,43$ \\
\hline Eixo Monumental & $\begin{array}{l}\text { Em } \\
\text { andamento }\end{array}$ & $70 \%$ & $5.076 .500,07$ & $17.632,53$ \\
\hline Riacho Fundo II & $\begin{array}{l}\text { Em } \\
\text { andamento }\end{array}$ & $93 \%$ & $1.606 .765,97$ & $8.033,35$ \\
\hline Park Way - Lote 1 & $\begin{array}{l}\text { Em } \\
\text { andamento }\end{array}$ & $99 \%$ & $1.731 .478,77$ & $12.980,05$ \\
\hline Park Way - Lote 2 & $\begin{array}{l}\text { Em } \\
\text { andamento }\end{array}$ & $72 \%$ & $1.994 .468,82$ & $14.374,16$ \\
\hline Park Way - Lote 3 & $\begin{array}{l}\text { Em } \\
\text { andamento }\end{array}$ & $87 \%$ & $1.538 .023,45$ & $11.289,84$ \\
\hline Lago Sul - Lote 1 & $\begin{array}{l}\text { Em } \\
\text { andamento }\end{array}$ & $30 \%$ & $3.637 .959,79$ & $13.405,33$ \\
\hline Lago Sul - Lote 2 & $\begin{array}{l}\text { Em } \\
\text { andamento }\end{array}$ & $1 \%$ & $1.285 .344,25$ & $5.287,28$ \\
\hline Lago Sul - Lote 3 & $\begin{array}{l}\text { Em } \\
\text { andamento }\end{array}$ & $20 \%$ & 3.093.661,92 & $10.337,53$ \\
\hline TOTAL & & & $41.300 .712,18$ & $171.374,63$ \\
\hline
\end{tabular}

Disponível em < http://www.novacap.df.gov.br/noticias/item/2358-df-\%C3\%A9refer\%C3\%AAncia-nacional-e-internacional-em-ciclovias.htm) >Acesso em 04 de set. de 2015 - (Projetos em processo de implementação)

Adiante, a Tabela $n^{\circ} 8$ apresenta o percentual da malha cicloviária em relação ao território das Regiões Administrativas de Vicente Pires, Águas Claras, Guará e Riacho Fundo 
II. Foram incluídos também os dados referentes às cidades de Brasília, Rio de Janeiro, São Paulo e Curitiba, que apresentam as malhas cicloviárias mais extensas do país . ${ }^{131}$

\section{Tabela no 8 - Território e Extensão Malha cicloviária}

\begin{tabular}{|l|c|c|c|}
\hline \multicolumn{1}{|c|}{$\begin{array}{c}\text { Cidade/Região } \\
\text { Administrativa }\end{array}$} & $\begin{array}{c}\text { Área Total } \\
(\mathrm{Km} 2)\end{array}$ & $\begin{array}{c}\text { Extensão da Malha } \\
\text { Cicloviária }(\mathrm{Km})\end{array}$ & $\begin{array}{c}\text { Território x Malha } \\
\text { cicloviária }\end{array}$ \\
\hline Brasília & $5.802(1)$ & $440(4)$ & $7,58 \%$ \\
\hline Rio de Janeiro & $1.264,296(1)$ & $374(4)$ & $29,58 \%$ \\
\hline São Paulo & $1.522,986^{(1)}$ & $265,5(4)$ & $17,43 \%$ \\
\hline Curitiba & $435(1)$ & $171(4)$ & $39,31 \%$ \\
\hline RA Guará & $37,50(2)$ & $5,76(5)$ & $15,36 \%$ \\
\hline $\begin{array}{l}\text { RA Riacho Fundo } \\
\text { II }\end{array}$ & $30,60(2)$ & $8,03(5)$ & $26,24 \%$ \\
\hline R.A Águas Claras & $31,50(2)$ & 0 & $0 \%$ \\
\hline RA Vicente Pires & $24,95(3)$ & 0 & $0 \%$ \\
\hline & & & \\
\hline
\end{tabular}

Disponível em < http://www.suapesquisa.com/> Acesso em 15 de out. de 2015. (1)

Fonte: Secretaria de Estado de Desenvolvimento Urbano e Habitação - SEDUH, 2012.(2) ${ }^{132}$

Dado Aproximado extraído de SEPLAN e CODEPLAN, 2006 apud ALVES, 2011. (3) ${ }^{133}$

Fonte: Prefeituras e União dos Ciclistas do Brasil - Dados de abril de 2015 (4). ${ }^{134}$

Disponível em < http://www.novacap.df.gov.br/noticias/item/2358-df-\%C3\%A9- refer\%C3\%AAncianacional-e-internacional-em-ciclovias.htm) >Acesso em 04 de set. de 2015 (5)

131 Dados de abril de 2015. Fontes: Prefeituras e União dos Ciclistas do Brasil. Disponível em< https://www.woie.com.br/blog/extensao-das-ciclovias-no-brasil-km/> Acesso em 29 de out. de 2015.

132 Anuário Descritivo do Distrito Federal 2012. Disponível em < www.codeplan.df.gov.br/.../274caracterizacao-do-territorio-descritivo.h...> Acesso em 04 de set. de 2015.

133 A Região Administrativa de Vicente Pires, incialmente Colônia Agrícola Vicente Pires, foi constituída inicialmente por 399 lotes de 5 hectares e por 10 lotes de 5 a 10 hectares, de acordo com dados da SEPLAN e CODEPLAN, 2006 apud ALVES, 2011, p.51. Tendo em vista que o processo de regularização de Vicente Pires ainda não foi concluído, os limites territoriais estão pendentes de definição, razão pela qual a extensão não consta no Anuário divulgado pela CODEPLAN conforme disposto no Anuário Descritivo do Distrito Federal 2012, p.5. Disponível em. <www.codeplan.df.gov.br/.../274-caracterizacao-do-territorio-descritivo.h...> Acesso em 04 de set. de 2015.

${ }^{i 34}$ Disponível em< https://www.woie.com.br/blog/extensao-das-ciclovias-no-brasil-km/> Acesso em 29 de out. de 2015. 
O critério utilizado (extensão da malha cicloviária $\mathrm{X}$ extensão territorial) representa apenas um elemento da política de valorização do transporte não-motorizado, outros aspectos, tais como a integração da malha e a instalação de equipamentos públicos, em razão da limitação temporal e de recursos, não serão abordados nesta pesquisa, o que poderá ser retomado futuramente.

Ainda, no tocante ao critério selecionado, convém trazer a baila a critica formulada pela representante do Movimento Rodas da Paz, Renata Florentina, por ocasião da Audiência Pública realizada na Câmara Legislativa do Distrito Federal em $1^{\circ}$ de novembro de 2013.A representante do referido movimento criticou a política de instalação de ciclovias, feita, segundo a mesma, "de forma desordenada e sem garantir a segurança" dos usuários e transeuntes. Florentino lembrou, ainda, que as calçadas continuam sem conservação e que a maioria dos prédios públicos, como a própria Câmara Legislativa, não ofereciam bicicletários à população. ${ }^{135}$

Em resposta às críticas acerca da ausência de integração entre as ciclovias e os outros transportes públicos e a falta de conexão entre os trechos, o Coordenador de Planejamento e Gestão da Casa Civil do DF, Paulo Passos, em entrevista ao Portal O Globo, em maio de 2013, reconheceu que as ciclovias são falhas, pois ainda estão inacabadas ${ }^{136}$.

\section{Ref.(iii) - Modicidade das tarifas}

A modicidade das tarifas para os usuários está consignada no at. $8^{\circ}$, inciso VI, da Lei $\mathrm{n}^{\mathrm{o}} 12.587 / 2012$ e no art. $6^{\circ}, \S 1^{\circ}$, da Lei $\mathrm{n}^{\mathrm{o}} 8.987 / 95$. A Lei de mobilidade urbana contempla diretrizes para o estabelecimento do valor da tarifa, que será o resultado do preço público cobrado ao usuário pelos serviços, somado à receita oriunda de outras fontes de custeio, visando cobrir os reais custos do serviço além da remuneração do prestador. Ainda segundo a Lei $\mathrm{n}^{\mathrm{o}} 12.587 / 2012$, compete ao poder delegante a fixação, o reajuste e a revisão da tarifa de

\footnotetext{
135 Disponível em <http://www.cl.df.gov.br/ultimas-noticias/-/asset publisher/IT0h/content/falta-planejamentointegrado-para-mobilidade-sustentavel-alertamespecialistas?redirect=http\%3A\%2F\%2Fwww.cl.df.gov.br\%2Finicio> Acesso em 10 dez 2014

136 Disponível em< http://g1.glob.com/bom-dia-brasil/noticia/2013/05/ciclovias-do-df-sofrem-com-falta-de continuidade-e-abuso-de motorias.html > Edição do dia 30/052013 12h:28 - Atualizado em 30/05/2013 15h28. Acesso em 10 dez. 2014
} 
remuneração da prestação do serviço público. Os reajustes deverão incluir a transferência de parcela dos ganhos de eficiência e produtividade das empresas aos usuários.

As tarifas de transporte público urbano nas principais capitais brasileiras apresentam entre seus itens de custos: pessoal e encargos; combustível; impostos e taxas; despesas administrativas; depreciação; remuneração; rodagem; lubrificantes; peças e acessórios. (CARVALHO et al, 2013. p.7) A necessidade de se estipular uma tarifa módica reside no fato de que os custos supracitados, segundo CARVALHO et al (2013, p.7), são, ao final, suportados pelos usuários.

Embora a Lei $n^{\circ} 8.987 / 95$ e a Lei $12.587 / 2013$ consignem o direito à modicidade tarifária, nenhum dos diplomas legais estipulou critérios para definir o que seria uma tarifa "módica".

A Lei $n^{\circ} 12.587 / 2013$ estabeleceu que, além da tarifa, podem ser utilizados outros recursos de forma complementar para cobrir os custos. A referida lei, porém, não definiu as fontes de tais recursos, nem os critérios a serem considerados para a complementação da receita obtida com as tarifas.

A respeito dos critérios para destinação de recursos complementares à tarifa, vale a pena registrar o estudo do Banco Mundial, desenvolvido ainda nos anos 80 do século passado. De acordo com estudos realizados por Alan Armstrong-Wright para o Banco Mundial, as tarifas podem ser consideradas "discriminatórias" quando um percentual superior a $10 \%$ das famílias gasta mais do que $15 \%$ da renda familiar nas viagens casa-trabalho; essa equação é denominada "Máxima de Armstong-Wright". De acordo com este critério, a política de preços administrados para o setor que previsse a complementação de recursos pelo Poder Público para custeio do serviço de transporte seria plenamente justificada desde que fossem verificados os percentuais combinados (10\% das famílias com $15 \%$ da renda comprometida com transporte). (Cf. BANCO MUNDIAL, 2003, p.43) ${ }^{137}$

\footnotetext{
137 A respeito do conceito de "Tarifa Suportável", o Banco Mundial indicou o seguinte: "[o] preço e a qualidade do serviço prestado são de óbvia importância na avaliação do impacto do transporte urbano sobre os pobres. O conceito de "preço tolerável" é popular e sedutor, e os governos com freqüência controlam as tarifas do transporte público, considerando que, se fixadas inaceitavelmente onerosas para os pobres. Ainda que não tenha sido originalmente criada como uma norma de política de preços, a "máxima de Armstrong-Wright" 24, de que podem ser vistas como discriminatórias as situações em que mais de $10 \%$ das famílias gastam mais de $15 \%$ de sua renda nas viagens para o trabalho, tem sido interpretada como regra razoável para determinar o nível de um preço politicamente administrado.

Deve-se recomendar cautela com relação a essa política. Em primeiro lugar, o impacto de qualquer patamar de custos de transporte sobre o nível agregado de bem-estar da família depende não apenas da sua renda e da tarifa. Nos casos em que se oferecem residência e aquecimento a preços muito baratos, por meio de subsídios públicos financiados pelos impostos (como acontece em muitas economias de transição), a proporção da renda líquida disponível para gastos com transporte pode ser correspondentemente mais alta. Porém, é importante que se lembre que o preço não é o único fator que conta. [...]” (BANCO MUNDIAL,2003, p.43) Disponível em <
} 
Em razão das restrições de tempo e financeiras, serão abordados neste trabalho acadêmico apenas os aspectos de consumo (referentes à fruição do direito de ir e vir) para o estabelecimento de índices sobre a modicidade das tarifas, o que não impede a complementação posterior, com a inclusão de índices relacionados aos custos de produção.

Considerando, no caso em tela, mais um componente econômico do direito de consumo focalizado (direito de ir e vir), informações úteis encontram-se em levantamento realizado pela revista Exame, que incorpora dados de estudo da OCDE. Tais informações dizem respeito à correlação entre salário mínimo e o preço da passagem em diversas cidades do mundo. ${ }^{138}$

Os dados divulgados pela Revista Exame apresentam os gastos mensais com transporte, considerando o valor despendido por usuários nos trajetos de ida e volta ao trabalho nos 20 dias úteis do mês, tendo como referência o valor do bilhete individual. Em sua pesquisa, a Exame converteu o dólar americano em reais pela cotação cambial do dia 9 de janeiro de 2015. ${ }^{139}$

Assim, com base nas informações indicadas (ver Tabela $\mathrm{n}^{\circ}$ 9, abaixo), e tendo em vista que a maior parte do transporte de passageiros no Distrito Federal é realizado por ônibus (conforme pesquisa realizada pela Câmara Legislativa do DF em 2012 -Tabela $n^{\circ}$ 10), foram considerados, para fins de representar formalmente o Índice de Fruição Empírica (IFE) na presente dissertação, os valores da chamada "Tarifa Metropolitana 2", ${ }^{140}$ trajeto longo, que liga as cidades satélites ao plano piloto. O valor dessa tarifa, desde de 2005 , é de $\mathrm{R} \$ 3,00$ (três reais), conforme estipulado pelo Decreto $n^{\circ}$ 26.501/2005, vigente sem alterações neste

http://wwwwds.worldbank.org/external/default/WDSContentServer/IW3P/IB/2005/10/20/000160016 20051020180730/Rend ered/PDF/24910a10portuguese1cities1on1the1move.pdf > Acesso em 10 de mar. de 2015.

${ }^{138}$ Disponível em <http://exame.abril.com.br/brasil/noticias/onibus-de-sp-e-o-que-mais-pesa-no-bolso-entre-12metropoles $>$ Acesso em 20 fev. 2015.

${ }^{139}$ Disponível em <http://exame.abril.com.br/brasil/noticias/onibus-de-sp-e-o-que-mais-pesa-no-bolso-entre-12metropoles $>$ Acesso em 20 fev 2015

140 As tarifas de ônibus no DF são definidas pelo Decreto $n^{\circ} 26.501 / 2005$, para cada uma das regiões atendidas:

- Metropolitana 1 (Ligação Curta): Cidade-Satélite / Plano Piloto.

- Metropolitana 2 (Ligação Longa): Cidade-Satélite / Plano Piloto.

- Metropolitana 3 (Ligação Intermediária): Cidade-Satélite / Cidade-Satélite; Cidade-Satélite / Plano Piloto.

- Urbana 1 (Circular Curta): Cidade-Satélite e Plano Piloto.

- Urbana 2 (Circular Longa): Cidade-Satélite e Plano Piloto.

- Urbana 3 (Circular Interna): Cidade-Satélite.

Disponível em < http://www.dftrans.df.gov.br/informacoes/tarifas.html $>$ Acesso em 10 jan. 2015 
ponto até a data de encerramento da redação do presente trabalho. Além disso, como se sabe, o salário mínimo brasileiro, a partir de janeiro de 2015 , foi fixado no valor de $\mathrm{R} \$ 788,00 .^{141}$

Tabela no 9 - Salário mínimo e valor da passagem

\begin{tabular}{|c|c|c|c|c|c|}
\hline País & Cidade & $\begin{array}{c}\text { Salário } \\
\text { mínimo } \\
\text { mensal em R\$ }\end{array}$ & $\begin{array}{c}\text { Tarifa de } \\
\text { onibus (bilhete } \\
\text { individual) em } \\
\mathbf{R} \$\end{array}$ & $\begin{array}{c}\text { Gasto } \\
\text { Mensal com } \\
\text { transporte } \\
\mathbf{( R \$ )}\end{array}$ & $\begin{array}{c}\text { Peso do } \\
\text { transporte } \\
\text { público no bolso } \\
\text { do trabalhador } \\
\text { (\%) }\end{array}$ \\
\hline Brasil & São Paulo & 788 & 3,5 & 140 & 17,77 \\
\hline Brasil & $\begin{array}{c}\text { Rio de } \\
\text { Janeiro }\end{array}$ & 788 & 3,4 & 136 & 17,26 \\
\hline Brasil & $\begin{array}{c}\text { Belo } \\
\text { Horizonte }\end{array}$ & 788 & 3,1 & 124 & 15,74 \\
\hline Portugal & Lisboa & $2.659,19$ & 5,62 & 224,8 & 8,45 \\
\hline Chile & Santiago & $1.074,76$ & 2,79 & 111,6 & 10,38 \\
\hline México & $\begin{array}{c}\text { Cidade do } \\
\text { México }\end{array}$ & 284,87 & 0,72 & 28,8 & 10,11 \\
\hline $\begin{array}{c}\text { Estados } \\
\text { Unidos }\end{array}$ & Nova York & $3.343,11$ & 6,63 & 265,2 & 7,93 \\
\hline Espanha & Madri & $2.659,19$ & 4,7 & 188 & 7,07 \\
\hline Israel & Tel Aviv & $3.168,20$ & 4,64 & 185,6 & 5,86 \\
\hline $\begin{array}{c}\text { Reino } \\
\text { Unido }\end{array}$ & Londres & $4.483,94$ & 6,02 & 240,8 & 5,37 \\
\hline Japão & Tóquio & $3.556,60$ & 4,43 & 177,2 & 4,98 \\
\hline França & Paris & $5.051,91$ & 5,62 & 224,8 & 4,45 \\
\hline
\end{tabular}

Fonte: OCDE/ Levantamento de EXAME.com ${ }^{142}$

141 O Decreto $\mathrm{n}^{\circ} 8.381 / 2014$ fixou o valor de $\mathrm{R} \$ 788,00$ para o salário mínimo nacional a partir de $1^{\circ}$ de janeiro de 2015.

${ }_{142}$ Disponível em < http://exame.abril.com.br/brasil/noticias/onibus-de-sp-e-o-que-mais-pesa-no-bolso-entre-12metropoles $>$ Acesso em 20 fev.2015. 
Ref. (iv) - Diversidade de Modais Públicos

A diversidade de modais tem como objetivo evitar a sobrecarga e subutilização dos mesmos, bem como reduzir a dependência de determinado meio de transporte e os prejuízos advindos da interrupção da prestação dos serviços correspondentes. A diversidade representa, portanto, objetivo a ser perseguido pelo formulador de política pública ao elaborar o plano de mobilidade urbana. (BRASIL, 2007, p.34)

A diversidade também é pressuposto para integração, que, por sinal, consiste em uma das diretrizes da Política Nacional de Mobilidade Urbana, conforme do art. $6^{\circ}$, inciso III, da Lei $n^{\circ} 12.587 / 2012$.

Segundo a ANTP (2012, parte II, p. 64-65), entre os maiores benefícios da integração entre os meios de transporte destacam-se a ampliação das redes de atendimento e o aumento da acessibilidade às diferentes áreas das cidades, o que significa a racionalização da prestação do serviço de transporte, facilitando as revisões de linhas e a supressão de superposições.

Registre-se, ainda, que a integração entre modais é acompanhada, na maioria das vezes, da integração entre tarifas, o que gera impactos positivos para o mercado de trabalho, principalmente para o mercado formal, visto que neste caso os empregadores são obrigados por lei a fornecer vale-transporte. A integração beneficia os trabalhadores que residem em lugares mais distantes, pois reduzem os gastos com vales-transportes para os empregadores. (ANTP - parte II, 2012)

Conforme dito anteriormente, a integração entre modais pressupõe a diversidade de modos de transporte disponíveis, principalmente públicos, e também a instalação de infraestrutura de transporte que contemple estacionamentos, bicicletários, locais específicos para embarque e desembarque de passageiros, etc.

Embora a instalação do metrô tenha sido apontada como fator principal para a ocupação do solo urbano em Águas Claras, tendo em vista que serviria como veículo facilitador da mobilidade urbana, o modal público mais utilizado tanto nesta RA, quanto em Vicente Pires continua sendo o ônibus comum, conforme pesquisa realizada pela Câmara Legislativa do Distrito Federal (CLDF) em 2012, tabela colacionada adiante. ${ }^{143}$

\footnotetext{
${ }^{143}$ Pesquisa realizada pela Câmara Legislativa do Distrito Federal. Pesquisa de Opinião. Metrô DF. Distrito Federal. Abril de 2012. Arquivo: Pesquisa_de_opinião_transporte_2012.pdf. Consulta Acervo Biblioteca Paulo Bertran.
} 
Tabela no 10 - Modal mais utilizado

Qual o transporte que o (a) $\mathrm{Sr}$ (a) mais usa?

\begin{tabular}{|l|c|c|c|}
\hline & Brasília & Vicente Pires & Águas Claras \\
\hline $\begin{array}{l}\mathrm{N}^{\circ} \text { de pessoas } \\
\text { entrevistadas }\end{array}$ & 260 & 97 & 179 \\
\hline Onibus/micro & $26,5 \%$ & $29,9 \%$ & $48,6 \%$ \\
\hline Carro particular & $81,9 \%$ & $53,6 \%$ & $35,2 \%$ \\
\hline Ônibus/micro/metrô & $3,5 \%$ & $8,2 \%$ & $8,4 \%$ \\
\hline $\begin{array}{l}\text { Carro particular } \\
\text { /Ônibus/Micro }\end{array}$ & $8,5 \%$ & $-1 \%$ & $3,4 \%$ \\
\hline $\begin{array}{l}\text { Carro particular/ } \\
\text { metrô }\end{array}$ & $0,8 \%$ & - & $3,9 \%$ \\
\hline Metrô & - & $5,2 \%$ & - \\
\hline $\begin{array}{l}\text { Onibus/micro/ } \\
\text { Transporte pirata }\end{array}$ & - & - & - \\
\hline Transporte pirata & $0,4 \%$ & - & - \\
\hline $\begin{array}{l}\text { Carro particular/ } \\
\text { Transporte pirata }\end{array}$ & - & $-6 \%$ \\
\hline NS/NR & & - & - \\
\hline
\end{tabular}

Fonte: CLDF, Pesquisa de satisfação, 2012.

A pesquisa de satisfação realizada pela CLDF entrevistou 3.878 pessoas em todo o Distrito Federal, no período entre 13 a 19 de abril de 2012. Foram entrevistadas 97 pessoas em Vicente Pires e 179, em Águas Claras. A qualidade na prestação do serviço de ônibus foi mal avaliada em ambas as regiões administrativas, conforme se dados indicados na Tabela $\mathrm{n}^{\circ}$ 10, adiante colacionada. ${ }^{144}$ De acordo com os moradores de Vicente Pires, o transporte

\footnotetext{
${ }^{144}$ Pesquisa realizada pela Câmara Legislativa do Distrito Federal. Pesquisa de Opinião. Metrô DF. Distrito Federal. Abril de 2012. Arquivo: Pesquisa_de_opinião_transporte_2012.pdf. Consulta Acervo Biblioteca Paulo Bertran.
} 
realizado por ônibus é considerado péssimo para 77,3\%; ruim para 12,4\%, regular para 4,1\%, bom para $1 \%$ e ótimo para $0 \%$.

Perguntados a respeito do meio de transporte mais utilizado, 29,9\% dos moradores responderam ônibus e 53,6\%, carros particulares, índice que revela a grande dependência do automóvel pelos moradores de Vicente Pires.

Segundo os moradores de Águas Claras, 50,8\% consideram o transporte de ônibus péssimo; ruim para 26,3\%; regular para 15,6\%; bom para 3,9\% e ótimo para $0 \%$. Questionados a respeito do meio de transporte mais utilizado, 48,6\% respondeu que utiliza os ônibus e $35,2 \%$ utiliza carro particular.

Tabela no 11 - Pesquisa de Satisfação

Como o(a) Sr(a) avalia o serviço oferecido pelas empresas de ônibus do DF?

\begin{tabular}{|l|l|l|l|}
\hline & Brasília & Vicente Pires & Aguas Claras \\
\hline $\begin{array}{l}\text { Número de pessoas } \\
\text { entrevistadas }\end{array}$ & 260 & 97 & 179 \\
\hline Ótimo & --- & --- & --- \\
\hline Bom & $3,5 \%$ & $1 \%$ & $3,9 \%$ \\
\hline Regular & $5,8 \%$ & $4,1 \%$ & $15,6 \%$ \\
\hline Ruim & $17,7 \%$ & $12,4 \%$ & $26,3 \%$ \\
\hline Péssimo & $70 \%$ & $77,3 \%$ & $50.8 \%$ \\
\hline NS/NR & $3,1 \%$ & $5,2 \%$ & $3,4 \%$ \\
\hline
\end{tabular}

Fonte: CLDF, Pesquisa de satisfação, 2012.

De acordo com o Caderno das Cidades de 2013 (GDF, 2013) ${ }^{145}$, que contém os projetos do governo do Distrito Federal para o referido ano, estavam previstos investimentos na área de mobilidade urbana visando à ampliação da capacidade do transporte público local. Entre os projetos previstos no setor de transportes, constavam a expansão do Metrô, a implementação do Expresso ${ }^{146}$ Eixos Sul e Oeste, a expansão e melhoria da malha cicloviária

\footnotetext{
145 Registre-se que este trabalho acadêmico optou por indicar os modais consignados no Programa do GDF visando, assim, afastar eventuais questionamentos a respeito da impossibilidade técnica para implementação dos mesmos nas referidas Regiões Administrativas, uma vez que a escolha de determinado meio de transporte deve observar questões de ordem técnica relacionadas às peculiaridades topográficas e ambientais do local no qual se pretende implementá-los.

146 O Expresso Eixo-Sul, como é chamado o Sistema Bus Rapid Transit (BRT) pelo governo do Distrito Federal, "baseia-se no conceito da utilização de um corredor exclusivo à circulação de ônibus, com direito específico de
} 
e a implementação do Veículo Leve sobre Trilhos (VLT) ${ }^{147}$, posteriormente retirado da matriz da Copa de 2014 pelo governo do GDF. ${ }^{148}$

Os projetos de mobilidade para Vicente Pires contemplaram apenas a implementação do Expresso. (GDF, 2013, p.134) Para a RA de Águas Claras, foi prevista a implementação de ciclovia e a implementação do expresso DF-Eixo Oeste. ${ }^{149}$ (GDF, 2013).

Verifica-se, assim, que o Distrito Federal como um todo e as RAs de Águas Claras e Vicente Pires, em particular, contam com uma oferta reduzida de meios de transporte público. A pouca diversidade de modais públicos se mostra ainda mais preocupante se for considerado que a grande maioria dos habitantes das sobreditas RAs precisam se deslocar diariamente até o Plano Piloto, principalmente, por motivos profissionais, conforme indicado na Tabela $\mathrm{n}^{\mathrm{o}} 12$, colacionada logo abaixo.

\section{Tabela no 12 - Número de habitantes $x$ número de deslocamentos por motivos profissionais (Ano 2011)}

\begin{tabular}{|c|c|c|}
\hline $\begin{array}{c}\text { Região } \\
\text { Administrativa }\end{array}$ & $\begin{array}{c}\mathbf{N}^{\mathbf{0}} \text { de habitantes que } \\
\text { trabalham na } \\
\text { própria RA }\end{array}$ & $\begin{array}{c}\mathbf{N}^{\mathbf{0}} \text { de habitantes que } \\
\text { trabalham em } \\
\text { Brasília }\end{array}$ \\
\hline Águas Claras & 9.820 & 23.930 \\
\hline Vicente Pires & 4.650 & 13.180 \\
\hline
\end{tabular}

Fonte: Pesquisa Distrital por Amostra de Domicílios do Distrito Federal PDAD/DF-2011 in: MIRAGAYA, 2013.

passagem, similar ao transporte metroviário" com a instalação de estações construídas para a facilitar o embarque e desembarque, além da cobrança da passagem. (ANTP, parte II, 2012, p.100)

${ }^{147}$ De acordo com a ANTP, o "VLT pode ser de superfície, com segregação parcial, variando desde o bonde moderno compartilhando a via com outros modos, até o LRT (dos americanos) ou o Tramway (dos franceses), com faixa reservada nas grandes avenidas e ruas, mas compartilhando a via até com pedestres nos centros históricos como Montpellier)”. (ANTP, parte II, 2012, p.110)

${ }^{148}$ O projeto do Veículo Leve sobre Trilhos (VLT) foi retirado da Matriz de Responsabilidade da Copa, pois as obras não ficariam prontas até o evento. Postado em 28/09/2012 16:32 / atualizado em 28/09/2012 21:03

Disponível em<

http://www.correiobraziliense.com.br/app/noticia/cidades/2012/09/28/interna cidadesdf,325044/vlt-deixa-deser-assunto-da-copa-e-nao-ficara-pronto-ate-o-evento.shtml > Acesso em 10 de jan. de 2015.

149 (GDF, 2013, p.109) Outras medidas foram indicadas, que embora digam respeito à politica de mobilidade (pavimentação de ruas, instalação de abrigos, etc.) não tratam especificamente da implementação de modais, bem como de sua integração, razão pela qual não foram consideradas neste quesito. Ademais, a simples indicação deveria ser comprovada por meio de pesquisa empírica, o que em razão do tempo e recursos não seria possível neste trabalho acadêmico. 
Definidos os elementos prestacionais a serem considerados, a próxima fase diz respeito à quantificação dos mesmos.

\section{D) Da quantificação}

Após a indicação dos conteúdos, o próximo passo, conforme orienta a AJPE, é a quantificação dos elementos no contexto da fruição empírica do direito em tela. A quantificação tem por objetivo a produção de índices ou indicadores: o Índice de Fruição Empírica (IFE) e o Padrão de Validação Jurídica (PVJ). A elaboração de tais referenciais, conforme já ressaltado, leva em conta o crescente uso desse tipo de recurso analítico para diversas finalidades no campo da elaboração e implementação de políticas públicas, cujas características se correlacionam à fruição de direitos subjetivos.

Quantificação (i) - Segurança (notação "S”)

Tendo em vista que o direito à vida é pressuposto para o exercício dos demais direitos, será atribuído peso 3 ao elemento prestacional segurança ("S"). Assim, será utilizada a fórmula (3 $\left.S^{*}-1\right)$, de modo que cada acidente fatal corresponda à pontuação negativa.

Será considerada a proporção entre acidentes com mortes e números de habitantes, considerando o número de acidentes ocorridos nas Regiões administrativas pesquisadas no período de 2005 até dezembro de 2014, conforme indicado nas Tabelas $n^{\circ} 4$ e $n^{\circ} 5$.

Quantificação (ii) - Prioridade de transporte não motorizado （notação “ $N$ ”)

Neste item foi considerada a proporção entre a extensão da malha cicloviária em relação ao território da Região Administrativa pesquisada, com base nos dados indicados nas tabelas $n^{\circ} 7$ e $n^{\circ} 8$. Será atribuído peso simples a este elemento. 
O Índice de Fruição Empírica será calculado considerando a extensão da malha cicloviária e a extensão territorial das RAs, tendo como referência os dados indicados na Tabela $n^{\circ} 6$ que apresenta o percentual de execução dos projetos de instalação da malha cicloviária no Distrito Federal, de acordo com a área ou região administrativa discriminada. Como se verá no item referente ao Padrão de Validação Jurídica (PVJ) mais adiante, serão considerados os percentuais entre extensão de ciclovias em relação ao território das Regiões Administrativas do Guará e do Riacho Fundo, indicados na Tabela $n^{\circ} 8$.

Quantificação (iii) - Modicidade da tarifa (notação “ $T$ ”)

Tendo em vista que o valor excessivo da tarifa tem o condão de afastar parcela considerável dos usuários do serviço público de transporte, conforme indicado na pesquisa do IPEA (CARVALHO et al, 2013), foi atribuído peso 2 a este elemento prestacional. Em seguida foi calculada a média aritmética dos percentuais apresentados pelo levantamento da Revista Exame/OCDE, que refletem o impacto do gasto com transporte sobre o salário mínimo em 12 (doze) cidades do mundo. As informações utilizadas referem-se ao gasto mensal de passageiros com transporte urbano, considerando o valor do salário mínimo e o valor despendido na ida e volta do trabalho nos 20 dias úteis do mês usando o bilhete individual. A média aritmética obtida foi de $9,6 \%(0,09)$.

Com vistas a obter os índices de Águas Claras e Vicente Pires, foram considerados o salário mínimo de $\mathrm{R} \$ 788,00$ e a tarifa de $\mathrm{R} \$ 3,00$ (três reais), relativa ao trajeto longo, que liga as cidades satélites ao plano piloto, conforme estipulado pelo Decreto $n^{\circ}$ 26.501/2005.

Considerando os critérios estabelecidos no levantamento Revista Exame/OCDE, a tarifa a $\mathrm{R} \$ 3,00$ (três reais) que corresponde ao gasto referente ao trajeto casa-trabalho-casa equivale ao gasto diário de $\mathrm{R} \$ 6,00$ (seis reais), este valor multiplicado pelo número de dias uteis (20 dias), obtém-se como resultado, $\mathrm{R} \$ 120,00$ (cento e vinte reais) por mês.

A correlação, em percentual, entre o valor do salário mínimo e o gasto mensal com a tarifa $(\mathrm{R} \$ 120,00)$ corresponde a $15 \%$ ou 0,15 . Os percentuais obtidos para ambas as Regiões Administrativas foram idênticos, pois a tarifa para o trajeto cidade satélite-plano piloto-cidade satélite é determinado pelo Governo Distrital e tem abrangência em todo o DF. Ressalte-se que neste cálculo foi considerado apenas o transporte por meio de ônibus e apenas o trajeto 
longo, sem a integração com os demais modais, mormente porque não há oferta de outros meios de transportes públicos em Vicente Pires.

Quantificação (iv) - Diversidade de modais públicos disponíveis (notação “M”)

Os meios de transporte públicos considerados nesta pesquisa foram aqueles indicados no programa formulado pelo Governo do Distrito Federal em 2013 (GDF, 2013), que incluía os seguintes meios de transporte: metrô, VLT, linhas de ônibus comum e BRT.

Conforme dito anteriormente, o VLT foi retirado da matriz da Copa em 2013; já o BRT, até março de 2014, contemplava os trechos do Gama, Santa Maria e Park Way até a Rodoviária do Plano Piloto, conforme sítio eletrônico do GDF. ${ }^{150}$ Foram atribuídos 1 ponto para cada um dos modais públicos: metrô, VLT, BRT(expresso) e linhas de ônibus comum, no total de 4 pontos. Foi atribuído peso simples a este elemento prestacional.

\section{E) Formulação do Índice de Fruição Empírica (IFE)}

O índice de fruição empírica proposto considera todos os cinco elementos prestacionais supramencionados, isto é: segurança (notação “ $S$ ”), transporte não motorizado (notação “ $N$ ”), modicidade das tarifas (notação “ $T$ ”) e diversidade de transporte público (notação “ $M$ ”). O resultado será obtido pela média aritmética alcançada.

\footnotetext{
150 De acordo com informação publicada no sítio eletrônico do GDF: “A partir de 28 de março, os cerca de 270 mil passageiros do sistema de transportes Eixo Sul (BRT Sul) pagarão R\$ 3 pela viagem. O serviço liga as regiões administrativas do Gama, do Park Way e de Santa Maria ao Plano Piloto. Segundo o Transporte Urbano do Distrito Federal (DFTrans), a integração continuará valendo. Assim, para se locomover entre uma dessas três localidades e o Plano Piloto, os passageiros pagarão apenas uma passagem". Disponível em< http://www.df.gov.br/conteudo-agencia-brasilia/item/18749brt-sul-ter\%C3\%A1-passagem-de-r\$-3-a-partir-de-28-de-mar\%C3\%A7o.html> Acesso em 30 de junho de 2015.
} 
Fórmula no 1 - Índice de Fruição Empírica (IFE)

$$
I F E=\frac{3(S *-1)+N+2 T+M}{4}
$$

Fórmula $\mathbf{n}^{\circ} 1.1$ - IFE quantificado de Águas Claras.

$$
\frac{I F E=3(-0,02)+0+2(0,15)+2}{4}=0,56
$$

Fórmula no 1.2 - IFE quantificado de Vicente Pires

$$
I F E=\frac{3(-0,01)+0+2(0,15)+1}{4}=0,31
$$

\section{F) Padrão de Validação Jurídica (PVJ)}

O Padrão de Validação Jurídica será a meta a ser atingida para que se considere a efetiva fruição do direito em relação às prestações que constam do IFE. No caso em tela, será obtido como resultado da média aritmética simples dos quatro elementos considerados. 
Recapitulando, o primeiro índice relativo à Segurança $(\mathrm{S})$ diz respeito ao número de acidentes com mortes que deverá ser igual a 0 (zero), ou seja nenhum acidente com vítima fatal.

$\mathrm{O}$ segundo item diz respeito à valorização do transporte não motorizado $(\mathrm{N})$, será considerada como PVJ, no caso, a proporção entre a extensão da malha cicloviária em relação ao território das Regiões Administrativas do Guará e Riacho Fundo II. Diferentemente do elemento modicidade tarifária, escolheu-se a média de duas Regiões Administrativas retromencionadas e não da totalidade das áreas apresentadas na Tabela $\mathrm{n}^{\circ} 7$, pois as demais não representam o percentual total das regiões administrativas, mas sim de áreas inseridas nas RAs. ${ }^{151}$ Portanto, a média aritmética obtida, considerando os percentuais das cidades de Brasília, Rio de Janeiro, São Paulo e Curitiba, além das Regiões Administrativas do Guará e Riacho Fundo II, foi de $22,58 \%$ ou 0,22 .

$\mathrm{O}$ terceiro elemento diz respeito à modicidade tarifária $(\mathrm{T})$, correspondente ao percentual do salário mínimo gasto com transporte da média das cidades apresentas na pesquisa Exame/OCDE. Neste caso será considerada módica a tarifa que corresponder a 9\% do salário mínimo ou 0,09, sendo esta a proporção com base nos dados sobre gastos com transporte urbano nas cidades apresentadas na pesquisa OCDE/Exame.

Por fim no elemento disponibilidade de modais (M), serão considerados para efeitos de cálculo os meios de transportes públicos cuja instalação foi indicada no Programa do GDF de 2013, no total de 4 (quatro) pontos, um ponto para cada modal.

A média aritmética desses quatro elementos deverá alcançar o total de 1,1, sendo este o Padrão de Validação Jurídica, ou seja o índice por meio do qual pode-se verificar, de forma objetiva, a fruição do direito à mobilidade urbana.

Fórmula no 2 - Padrão de Validação Jurídica (PVJ)

$$
P V J=\frac{(3 * 0)+0,22+(2 * 0,09)+4}{4}=1,1
$$

\footnotetext{
${ }^{151}$ A Tabela no 7 apresenta o percentual de lotes do Gama e do Park Way, por exemplo, e não a área total das referidas regiões administrativas.
} 


\section{REVISITANDO A POLÍTICA DE MOBILIDADE}

Considerando os resultados obtidos pela aplicação do índice de fruição empírica, a AJPE abre ao jurista/pesquisador a oportunidade para formular propostas para a política pública analisada, o que será tratado neste item.

Após a adoção das etapas previstas na metodologia da AJPE, foi obtido o índice de 1,1 , sendo este a meta a ser alcançada como Padrão de Validação Jurídica (PVJ) para que se possa considerar que a política publica é exitosa em garantir a fruição do direito à mobilidade urbana.

Todavia, enquanto o PVJ obtido foi de 1,1, Águas Claras obteve o índice de 0,56 e Vicente Pires, o índice de 0,31. Verifica-se que ambas as RAs estão distantes da meta pela qual se pode considerar, de maneira objetiva, que a política pública desenvolvida é bem sucedida ao garantir a fruição ao direito à mobilidade urbana.

No tocante ao elemento prestacional Segurança (“S”), ambas as RAs tiveram valores negativos, o que demanda do poder público a adoção de medidas visando à redução dos índices de acidentes. A incidência de vítimas fatais no trânsito deve ser monitorada por meio de pesquisas que indiquem não apenas o número, mas também a relação entre os acidentes e as infrações de trânsito. De posse de tais informações, o DETRAN/DF poderá monitorar possíveis reincidentes e assim atuar de forma diligente na aplicação de sanções mais severas, como a cassação da Carteira Nacional de Habilitação (CNH). ${ }^{152}$ Embora seja vedado ao poder local alterar a penalidade, o maior controle por parte do Departamento de Trânsito do DF pode evitar a circulação de condutores que já tenham ultrapassado o limite de pontuação indicado pelo CTB para suspensão do direito de dirigir ou cassação da Carteira Nacional de Habilitação. Além dessas medidas, também recomenda-se a intensificação de campanhas educativas para a segurança do trânsito, conforme previsto no CTB.

Com relação ao elemento diversidade de modais ("M"), deve-se considerar as especificidades de cada RA. Embora escape aos objetivos deste trabalho acadêmico questionar a legalidade da ocupação de Vicente Pires, cuja urbanização começou de forma não planejada e se intensificou nos últimos anos, é imprescindível que se observe que tal expansão ocorreu em área rica de mananciais. Assim, considerando a importância da área, a

\footnotetext{
${ }^{152}$ De acordo com o art. 263 da Lei no 9.507/93, a CNH poderá ser cassada quando suspenso o direito de dirigir o condutor for flagrado dirigindo qualquer veículo, no caso de reincidência e quando houver condenação judicial por delito de trânsito. A reincidência consiste em incidir, no prazo de 12 meses, nas infrações previstas no inciso III do art. 162 e nos arts, 163, 164, 165, 173, 174 e 175 do CTB.
} 
ausência de projetos prevendo a implementação de infraestrutura para meios de transporte menos poluentes (ciclovias ou VLT) no Programa apresentado pelo GDF, aumenta a dependência da população local dos veículos movidos por combustível fóssil, cujas externalidade já foram apresentadas neste trabalho.

Conforme indicado na pesquisa desenvolvida pela Câmara Legislativa do Distrito Federal em 2012 (Tabela n ${ }^{\circ}$ 10) , 53,6\% dos moradores de Vicente Pires utilizam o automóvel como principal meio de transporte. Considerando a situação especial de Vicente Pires, urge a necessidade de adoção de medidas visando não apenas o controle da expansão urbana, mas também a adoção de política de mobilidade urbana visando à diminuição dos danos ambientais, para o fim de assegurar a fruição dos direito de ir e vir nessas regiões em termos mais justos, conforme indicado pela pesquisa realizada neste trabalho.

Não obstante a ocupação de Águas Claras tenha sido planejada e a referida Região Administrativa conte com maior diversidade de meios de transportes, o índice de 0,56, obtido na pesquisa apresentada, corrobora os questionamentos a respeito da eficácia da infraestrutura dos transportes públicos na referida RA, divulgados pela imprensa. ${ }^{153}$ Acerca do planejamento de Águas Claras, convém esclarecer que, embora a região tenha sido planejada, ao longo do tempo a ocupação do solo foi sofrendo alterações em seu projeto original, tais alterações, contudo, não foram acompanhadas por uma política de mobilidade eficaz, conforme se verifica pelo índice negativo obtido nesta pesquisa ${ }^{154}$.

A política de mobilidade urbana deve ser considerada como parte do planejamento urbano, conforme salientado no capítulo 1. A politica de mobilidade não se resume à politica de transporte, de modo que a simples implementação de um meio de transporte, mesmo que

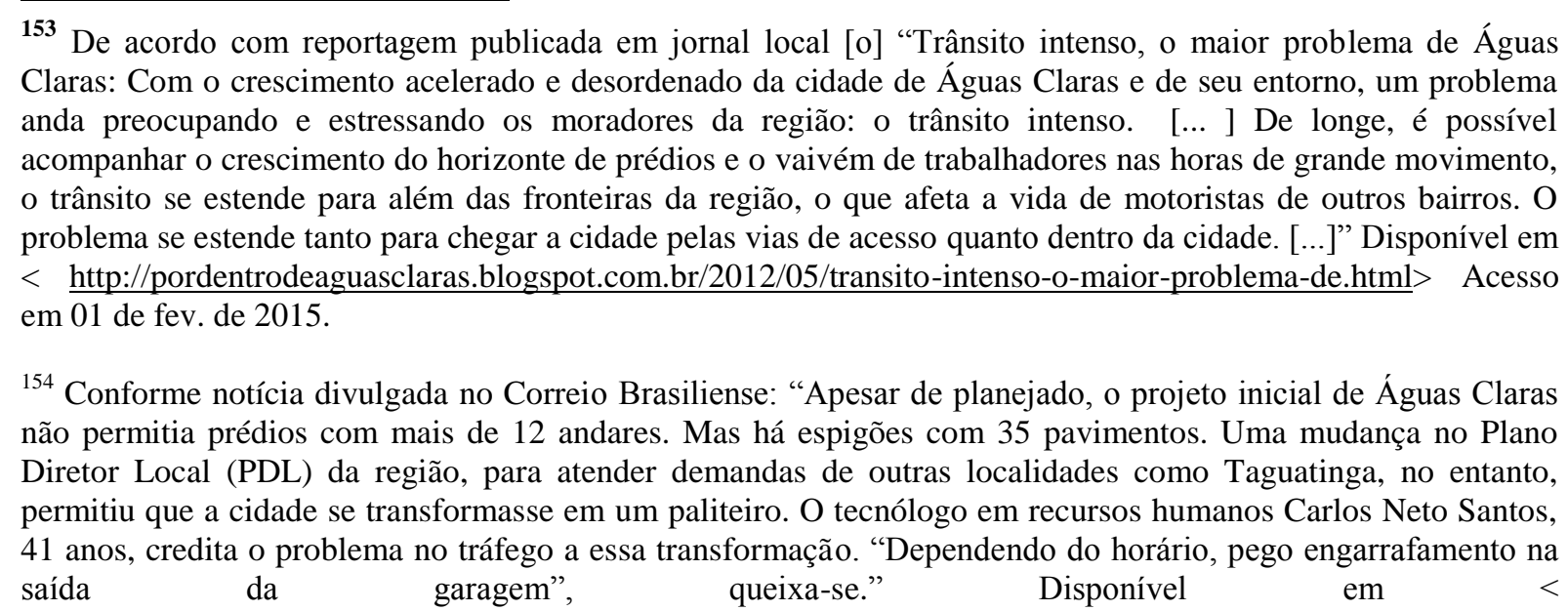
http://www.correiobraziliense.com.br/app/noticia/cidades/2015/03/28/interna cidadesdf,477365/moradores -de-aguas-claras-e-vicente-pires-reclamam-de-infraestrutura.shtml > Acesso em 28 de mar de 2015. 
de grande porte como o metrô, sem que sejam adotadas outras medidas de planejamento urbano, não será suficiente para tornar eficaz a politica de mobilidade urbana.

Como sugestão para melhoria da mobilidade na RA de Águas Claras, indica-se o início imediato de estudos a respeito da implementação de rodízio de veículos. Além desta sugestão, recomenda-se a realização de pesquisa a respeito da correlação entre os prédios e garagens, de modo a certificar se existem vagas para os automóveis dos residentes, bem como a identificação dos lugares onde estão sendo estacionados os veículos. Nunca é demais registar que o estacionamento em calçadas, além de dificultar a mobilidade, é prática vedada pelo Código de Trânsito Brasileiro. ${ }^{155}$

Considerando a necessidade de se incentivar a um só tempo a diversidade de serviços e o transporte não motorizado, recomenda-se a realização de estudo pela Administração, tanto para Águas Claras quanto para Vivente Pires, acerca da possibilidade de implementação de benefícios fiscais para a iniciativa privada visando à instalação, manutenção e extensão da malha cicloviária, bem como a prestação de serviços de estacionamento e aluguel de bicicletas. De acordo com dados da Associação Nacional do Transporte Público, quando instaladas em área pavimentada, o valor de instalação de ciclofaixas está estimada em cerca e R\$ 0,1 a 0,2 milhões por quilômetro. (ANTP, parte II, 2012, p.41) Ressalte-se, contudo, que não basta a instalação de ciclovias ou ciclofaixas, se estas não estiverem interligadas ao sistema cicloviário e aos demais meios de transporte.

Por fim, no tocante ao elemento modicidade tarifária, convém registrar que, em atenção ao que determina a Lei de Mobilidade Urbana e em respeito à transparência da política tarifária, o governo do Distrito Federal divulgou em seu portal eletrônico o procedimento para o cálculo tarifário, bem como a planilha de custos correspondentes ao serviço básico. ${ }^{156}$

Conforme descrito na sobredita planilha, foram calculados os valores considerando $100 \%$ da quilometragem programada sob a justificativa de que "não há dados disponíveis que comprovem a realização e admissão de quilometragem"; além disso, os dados, segundo o referido sítio eletrônico, não foram auditados. Considerando as respostas obtidas nas pesquisas realizadas pela Câmara Legislativa do Distrito Federal (Tabela $\mathrm{n}^{\circ} 11$ ) a respeito da

155 "Estacionar veículo sobre a calçada ou faixa de pedestre" - Código de Trânsito Brasileiro (CTB) - Art. 181, inciso VIII Infração: Grave - 05 (cinco) pontos Penalidade: Multa - R\$ 127,69. Medida administrativa: Remoção do veículo.

${ }^{156}$ Disponível em< http://www.dftrans.df.gov.br/images/PDFs/composicao\%20das\%20tarifas.pdf $>$ Acesso em 20 de jan. 2015. 
qualidade do serviço de transporte urbano realizado por ônibus, considera-se imprescindível a adoção por parte do poder publico de instrumentos capazes de medir a execução do serviço prestado, considerando o tempo e a quilometragem.

Além da contribuição de especialistas na área tecnológica, imprescindível ao tema, registre-se desde já a existência de "tacógrafos", aparelhos registradores instantâneos e inalteráveis de velocidade e tempo, cujo uso é obrigatório para veículos que transportam carga com peso bruto total superior a $4536 \mathrm{KG}$, conforme determinação da Resolução CONTRAN 14/98, e para veículos de passageiros com mais de 10 (dez) lugares, conforme Resolução CONTRAN nº 87/99, sem prejuízo da adoção de outros meios eletrônicos de fiscalização e do uso integrado dos instrumentos de engenharia de tráfego; razão pela qual recomenda-se ao Poder Público o fortalecimento da fiscalização dos instrumentos e meios já identificados na legislação pertinente.

Insta ressaltar que a ausência de dados confiáveis a respeito do cumprimento da quilometragem e dos horários pelas concessionárias prejudica a análise a respeito da adequação dos valores para o cálculo das tarifas, bem como a real necessidade de eventuais reajustes tarifários.

Recomenda-se, por fim, a discussão a respeito das cláusulas contratuais consignando para tanto multas correspondentes aos atrasos e falhas dos serviços de transporte urbano, devendo o valor arrecadado em razão do descumprimento contratual ser utilizado na melhoria do serviço de transporte, conforme previsto na Lei de Mobilidade Urbana. 


\section{CONCLUSÃO}

A política de transportes desenvolvida no Brasil desde o período imperial sempre esteve intimamente ligada aos demais aspectos da política econômica, ora fortalecendo determinado setor, no caso o agrícola, por meio da instalação de ferrovias, ora incentivando o processo de industrialização tardio por meio da mudança da matriz de transporte e da instalação de indústrias automobilísticas.

No Capítulo 1 desta Dissertação foi apresentado um breve histórico a respeito da legislação do setor do transporte e seu respectivo contexto político e econômico. Neste capítulo também foi apresentada a mudança de paradigma, cujo foco não mais reside no "direito ao transporte", mas sim no "direito à mobilidade urbana", aquele mais preocupado com os setores da economia, este mais preocupado com a fruição do próprio direito de ir e vir. Importante destacar que em alguns casos o transporte inadequado será o principal obstáculo à mobilidade, conforme se percebe pelos inúmeros engarrafamentos nas cidades brasileiras.

Objetivando demonstrar a distância entre o discurso jurídico predominante no Brasil, referenciado na dogmática jurídica e no neoconstitucionalismo eclético, foi apresentado no Capítulo 2 o estudo da decisão proferida pelo Supremo Tribunal Federal no julgamento da ADI n 3.768-4, ajuizada em 2006 pela NTU, que buscava afastar a aplicação imediata do art. 39 do Estatuto do Idoso.

A decisão em comento, fundamentada ao mesmo tempo no formalismo e nos aspectos morais do princípio da solidariedade, esquivou-se em analisar com mais profundidade a regressividade da concessão de gratuidade à parcela da população com poder aquisitivo superior a dos demais usuários pagantes, em identificar os responsáveis "solidários" pelo ônus referente à gratuidade do transporte e em debater outras fontes de financiamento do sistema de transporte, além da tarifa.

Assim, visando ultrapassar a insuficiência do discurso jurídico predominante no Brasil, foi apresentado no Capítulo 3 as abordagens da Análise Econômica do Direito (AED), cuja escolha se deveu a sua influência no meio acadêmico norte-americano, principalmente a partir da década de 50, e, em contraposição, a Análise Jurídica da Política Econômica (AJPE). No referido capítulo foram apresentas as críticas à AED, em especial ao emprego pela mesma dos elementos da economia clássica e neoclássica na análise jurídica e sua preocupação com as escolhas racionais, muitas vezes divorciadas dos valores e conteúdos não econômicos, como no clássico exemplo apresentado por Coase a respeito dos motivos 
econômicos para a rejeição ao dever de indenizar em razão de incêndios nas florestas adjacentes às linhas férreas causados pelo trafego ferroviário.

Em oposição à AED, a AJPE inova ao propor a análise dos aspectos jurídicos não apenas dos contratos administrativos (agregados contratuais) em sua visão tradicional, mas também dos "pactos sociais" e das expectativas que estes geram para a sociedade. Assim, a AJPE, ao contextualizar o direito, revela as relações ocultas que muitas vezes impedem o exercício do mesmo e que, portanto, não podem ser subtraídas do debate, principalmente o acadêmico.

No Capítulo 4 foi apresentada a metodologia da AJPE, de forma exemplificativa, por meio da análise de dados das Regiões Administrativas de Águas Claras e Vicente Pires. A metodologia da AJPE, conforme indicado no capítulo 4, consiste em identificar a política pública e o direito fundamental correlato. Uma vez identificado o direito, o pesquisador deverá realizar a decomposição analítica que consiste em identificar os elementos prestacionais necessários à caracterização do mesmo. No caso do direito de ir e vir, foram identificados como elementos: o direito à segurança, ao incentivo ao transporte não motorizado, à modicidade tarifária e à diversidade de modais públicos disponíveis na região pesquisada. Embora muitos outros elementos pudessem ser identificados como necessários à caracterização do direito de ir e vir, a pesquisa se limitou a indicar os quatro elementos em virtude de limitações na obtenção de dados e da confiabilidade dos mesmos.

Os elementos supramencionados foram organizados em um índice denominado Índice de Fruição Empírica (IFE) que visa verificar de modo objetivo o gozo de cada um dos elementos que compõe o direito de ir e vir. Obtidos os índices quantificados de Águas Claras e Vicente Pires pela aplicação da fórmula do IFE, estes foram comparados ao Padrão de Validação Jurídica (PVJ), que nada mais é do que o índice necessário à verificação empírica da fruição do direito.

Por fim, foram apresentadas sugestões de reforma da politica de mobilidade urbana nas regiões supracitadas, com base nos índices obtidos pelo uso da metodologia da AJPE. A decomposição do direito analisado e a formulação de indicadores, conforme metodologia desenvolvida pela AJPE, permite que se discuta questões até então inseridas na esfera política de modo a explicitar as deficiências na fruição dos direitos e possibilitar ao jurista a formulação de propostas para superação dessas deficiências.

A dissertação procurou com isso demonstrar de que modo o discurso jurídico pode se libertar do culto às formas abstratas (formalismos e principiologias abstratas), se aproximando 
da realidade empírica; realidade esta mais complexa e variada do que supõem os conceitos “prontos” tão ao gosto da tradição jurídica brasileira. (CASTRO, 2014).

Importante ressaltar que embora se aproxime da realidade empírica e considere os aspectos econômicos subjacentes às políticas públicas, a AJPE considera não apenas esses aspectos, mas também os aspectos não-econômicos que apresentam conteúdo social, moral, ambiental e político. Neste sentido, os resultados obtidos na pesquisa utilizando a metodologia da AJPE sobre os elementos prestacionais do direito à mobilidade urbana na Região Administrativa de Águas Claras que em sua origem, de certo modo, representava o antigo paradigma centrado na "política de transporte" (no caso o metrô), sem a correspondente integração com a política de planejamento urbano sustentável, revela de modo objetivo a insuficiência da política de mobilidade urbana adotada para a referida RA.

Do mesmo modo, apesar dos impactos ambientais produzidos pela ocupação não planejada da RA de Vicente Pires que não conta com uma política pública clara voltada para a regularização fundiária ou de implementação de meios de transportes menos poluentes indicam o quanto a política, ou a ausência de uma política pública voltada para garantia da fruição do direito de ir e vir, revela o pouco apreço dos policy makers pelos aspectos econômicos, sociais, ambientais e morais que deveriam balizar suas escolhas políticas.

Destarte, o discurso jurídico constitucional conforme defendido pela AJPE, não mais limitado ao culto das formas abstratas, possibilita ao jurista debater questões relacionadas aos múltiplos aspectos da política e da economia, possibilitando-lhe propor sugestões de reforma que sejam capazes de assegurar a fruição dos direitos, garantido, deste modo, a transformação da realidade social. 


\section{REFERÊNCIAS BIBLIOGRÁFICAS}

ABREU, Marcelo de Paiva (Org.). A ordem do progresso: cem anos de política econômica republicana, 1889-1989. Rio de Janeiro: Campus, 1990.

ACIOLI, Rodrigo Girdwood. Os mecanismos de financiamentos das ferrovias brasileiras. 2007. 195 f. Dissertação de Mestrado em Engenharia, COPPE/UFRJ, M Sc. Programa de Engenharia de Transporte, Universidade Federal do Rio de Janeiro, 2007.

ALEXY, Robert. El concepto y la validez del derecho. $2^{\text {a }}$ ed. Barcelona: Gedisa, 1997.

. Teoria dos direitos fundamentais. São Paulo: Malheiros Editores, 2008.

Direito, Razão, Discurso. Estudos para a filosofia do direito. Porto alegre:

Livraria do Advogado Editora, 2010.

ALVES, José Conceição Lopes. Ocupação Urbana. Ocupação urbana e impactos ambientais - o reverso da ocupação irregular em Brasília/DF.2011. 106f . Dissertação de Mestrado Programa de pós-graduação em Sociedade, Tecnologia e Meio Ambiente - Centro Universitário de Anápolis - UniEvangélica, 2011. Disponível em<http://www.unievangelica.edu.br/files/images/disserta\%C3\%A7\% C3\% A3ozequinh a.pdf $>$ Acesso em 05 de set. de 2015.

ANTP. Gestão da Mobilidade Urbana - Parte I. São Paulo: Associação Nacional dos Transportes Públicos e SENAC, 2012.

. Gestão da Mobilidade Urbana - Parte II. São Paulo: Associação Nacional dos Transportes Públicos e SENAC, 2012.

Gestão da Mobilidade Urbana - Parte III. São Paulo: Associação Nacional dos Transportes Públicos e SENAC, 2012.

ARANHA, Márcio Iório. Manual de Direito Regulatório. (Fundamentos de Direito Regulatório) Scotts Valley, CA: Create Space, 2013. 
ÁVILA, Humberto. Teoria dos Princípios. Da definição à aplicação dos princípios jurídicos. $11^{\mathrm{a}}$ ed. Malheiros Editores: São Paulo, 2005.

AVILA, Humberto. "NEOCONSTITUCIONALISMO": ENTRE A "CIENCIA DO DIREITO" E O "DIREITO DA CIÊNCIA”. Revista Eletrônica de Direito do Estado (REDE), Salvador, Instituto Brasileiro de Direito Público no 17, janeiro/fevereiro/março de 2009. Disponível na internet < http://www.direitodoestado.com.br/rede.asp $>$ acesso em 20 de dezembro de 2014.

BANCO MUNDIAL. Cidades em movimento: estratégia de transporte urbano do Banco Mundial. São Paulo: Sumatra Editorial, 2003. Disponível em < http://wwwwds.worldbank.org/external/default/WDSContentServer/IW3P/IB/2005/10/20/000160016_20 051020180730/Rendered/PDF/24910a10portuguese1cities1on1the1move.pdf > Acesso em 10 de mar. de 2015.

BARROSO, Luis Roberto. O Direito Constitucional e a Efetividade de suas Normas. Limites e possibilidades da Constituição Brasileira. $7^{a}$ ed. Rio de janeiro: Renovar, 2003.

BENTHAM, Jeremy. An introduction to the principles of morals and legislation. In: BOWRING, John (coord). The Works of Jeremy Bentham. Edinburgh: William Tait, v. I, 1838-1843. Disponível em< http://oll.libertyfund.or/title/2009/138947 Acesso em dezembro de 2014.

BOBBIO, Norberto. Teoria do Ordenamento Jurídico. $6^{\mathrm{a}}$ ed. Brasília: Editora Universidade de Brasília, 1995.

BRASIL, Ministério das Cidades. Plan Mob: construindo a cidade sustentável. Caderno de Referência para Elaboração de Plano de Mobilidade Urbana, n 1, 2007.

BUCCI, Maria Paula Dallari. (Org.) Políticas públicas: reflexões sobre o conceito jurídico. São Paulo, 2006.

CÂMARA LEGISlativa DO DISTRITO FEDERAL. Pesquisa de Opinião. Metrô DF. Distrito Federal. Abril de 2012. Arquivo: Pesquisa_de_opinião_transporte_2012.pdf. Consulta Acervo Biblioteca Paulo Bertran.

CAMPOS, Juliana Cristine Diniz e ALBUQUERQUE, Felipe Braga. Nova Hermenêutica constitucional e (in)segurança jurídica: características e crítica a virada linguística no 
interpretar da Constituição. Questio Iuris. . Rio de Janeiro Vol. 08. N 02, p.774-792, 2015. DOI: http://dx.doi.org/10.12957/rqi.2015.16914.

CARBONELL, Miguel (Coord.) NEOCONTITUCIONALISMO(S). Madrid: Editorial, 2003.

CARVALHO, Carlos Henrique Ribeiro de; GOMIDE, Alexandre; PEREIRA, Rafael Henrique Moraes; MATION, Lucas Ferreira; BALBIM, Renato; NETO, Vicente Correa Lima; GALINDO, Ernesto Pereira; KRAUSE, Cleandro; GUEDES, Erivelton Pires. NOTA TÉCNICA: Tarifação e financiamento do transporte público urbano. Brasília: IPEA, 2013.

CARVALHO JÚNIOR, Wilson Martins. Expansão Urbana em Brasília- DF: Ausência de planejamento urbano e riscos aos mananciais das bacias do Riacho Fundo e Paranoá. Revista Projeção e Docência _ v. $2_{\text {_ n. }} 1_{\text {_ }}$ p. 20-00 _ mar._ 2011 Recebido em: 25/03/2011. Aprovado em: 29/03/2011. Disponível em <revista.faculdadeprojecao.edu.br/index.php/Projecao3/article/.../40/3> Acesso em $20 \mathrm{dez}$ 2014.

CASTRO, Marcus Faro de. Análise Jurídica da Política Econômica in. Revista da PGBC vol. 3, n. 1, jun. 2009.

Formas jurídicas e mudanças sociais: interações entre o direito, a filosofia, a política e a economia. São Paulo: Saraiva, 2012.

.Economic Development and the Legal Foundations of Regulation in Brazil. Law and Development Review. DE GRUYTER doi 10.515/Ldr - 2013-0003 LDR 2013.

Novas Perspectivas Jurídicas sobre a Reforma de Políticas Públicas no Brasil. Revista Direito UnB, vol. 1, p. 32-64, 2014.

.Globalização, Democracia e Direito Constitucional: Legados Recebidos e Possibilidades de Mudança, in Clèmerson Merlin Clève; Alexandre Freire (coords.). Direitos Fundamentais e Jurisdição Constitucional: Análise, Crítica e Contribuições. São Paulo: Editora Revista dos Tribunais, p. 697-719, 2014a. 
Direitos Sociais, Econômicos e Culturais: Uma Abordagem Pós-Neo-Clássica. Revista Jurídica da Presidência da República Ago, Brasília, v. 7, n.74, Set 2005. Disponível em < http://www.planalto.gov.br/ccivil_03/revista/Rev_74/artigos/Marcus_rev74.htm > Acesso em 20 de out. de 2015.

CAVALIERI FILHO, Sérgio. Programa de Responsabilidade Civil. $8^{\mathrm{a}}$ ed. São Paulo: Atlas, 2008.

CITTADINO, Gisele. Pluralismo, Direito e Justiça Distributiva. Elementos da Filosofia Constitucional Contemporânea. $4^{\text {a }}$ edição. Rio de Janeiro: Editora Lumen Juris, 2009.

COASE, Ronald. The Problem of social cost. The Journal of Law and Economics. The University of Chicago Pres. Volume III. October, p.1-44, 1960. Disponível em< http://www2.econ.iastate.edu/classes/tsc220/hallam/Coase.pdf $>$ Acesso em 10 de ou. De 2014.

COUTINHO, Diogo R.; MARQUES, Juliana N.; MORETTI, Julia Azevedo; PACHECO, Marcelo G.; ROZO, Fernanda F.G. $O$ Direito nas Políticas Públicas Urbanas $e$ Habitacionais: o uso de instrumentos urbanísticos no Município de Santo André, São Paulo. Cadernos Gestão Pública e Cidadania, v. 19, n. 64, Jan/jun, 2014.

DAVIS, Kevin E.; KINGSBURY, Benedict; MERRY, Sally. INDICATORS AS A TECHNOLOGY OF GLOBAL GOVERNANCE. Global Administrative Law Series. New York University School of Law IILJ Working Paper 2010/2 Rev (revised August 2011).

DENATRAN. Manual de procedimentos para o tratamento de pólos geradores de tráfego. Brasília: DENATRAN/FGV, 2001.

DUMONT, Louis. HOMO AEQUALIS. Bauru, SP: EDUSC, 2000.

DUNLOP, C.J. Apontamentos para a História dos Bondes no Rio de Janeiro. Rio de Janeiro: Editôra Gráfica Laemmet Ltda., 1953.

DWORKIN. Ronald. Levando os direitos a sério. $3^{\mathrm{a}}$ ed. São Paulo: WMF Martins Fontes, 2000. 
EICHENGREEN, Barry. Financing Infrastructure in Developing Countries: Lessons from the Railway Age. Econonomics Department WP 94-230, October, 1994. Disponível em < http://eml.berkeley.edu/ eichengr/research.html > Acesso em 13/11/2014.

FALCÃO, Alcino Pinto. Constituição Anotada. Volume II - Arts. 129 a 144 (Da Declaração de Direitos) . Rio de Janeiro: José Konfino Editor, 1957.

FERNANDES, Edésio \& ALFONSIN, Betânia (Org). DIREITO URBANÍSTICO. Estudos Brasileiros e Internacionais, Belo Horizonte: Del Rey, 2006.

FERREIRA, Waldemar Martins. História do Direito Constitucional Brasileiro. Ed. Facsimilar. Brasília: Senado Federal, Conselho Editorial, 2003.

FIGUEIREDO, Leonardo Vizeu. Lições de Direito Econômico. Rio de Janeiro: Forense, 2009.

GANDRA, Ives da Silva Martins. (org.) Curso de Direito Tributário. 10 a ed. São Paulo: Editora Saraiva, 2008.

GDF. Caderno das Cidades. Projetos e ações do Governo do Distrito Federal nas Regiões Administrativas, 2013. Disponível em< http://www.transparencia.df.gov.br/Planejamento\%20Oramento\%20\%20Relatrios\%20Gerenc iais/caderno_cidades\%202013.pdf $>$ acesso em 10 de dez. de 2014.

GUIMARÃES, Geraldo Spagno. Comentários à Lei de Mobilidade Urbana - Lei $\mathrm{n}^{\circ}$ 12.587/12: essencialidade, sustentabilidade, princípios e condicionantes do direito à mobilidade. Belo Horizonte: Fórum, 2012.

HOLMES, Stephen and SUNSTEIN, Cass R. The Cost of Rights. Why Liberty depends on taxes. New York: W.W Norton Company, 2000.

IBRAHIM, Fábio Zambitte. Curso de Direito Previdenciário. $11^{\mathrm{a}}$ ed. Rio de Janeiro: Impetus, 2008. 
IPEA. História - Encilhamento: crise financeira e República - Objetivo era promover a industrialização brasileira, mas o resultado foi um surto inflacionário. Revista Desafios do Desenvolvimento - IPEA. Brasília, Ano 8, Edição 65, 2011. Disponível em < http://www.ipea.gov.br/desafios/index.php?option=com_content\&view=article\&id=2490: cati $\underline{\mathrm{d}=28 \& \text { Itemid }=23}>$ Acesso em 16 fev. 2015

Mobilidade Urbana. O automóvel ainda é prioridade. Revista Desafios do Desenvolvimento - IPEA. Brasília, Ano 8, Edição 67, 2011a. Disponível em < http://www.ipea.gov.br/desafios/index.php?option=com_content\&view=article\&id=2490:cati $\underline{\mathrm{d}=28 \& \text { Itemid }=23}>$ Acesso em 16 fev. 2015

. Serie Eixos do Desenvolvimento Brasileiro $N^{o}$ 94. Infraestrutura Social e Urbana no Brasil subsídios para uma agenda de pesquisa e formulação de políticas públicas. A mobilidade Urbana no Brasil. 2011b. Disponível em < http://www.energiaeambiente.org.br/arquivos/files/comunicadoipea.pdf $>$ Acesso em 15 de jan. de 2015.

KELSEN, Hans. Teoria Pura do Direito. 6ª ed. São Paulo, Martins Fontes, 1998.

KENNEDY, David. Law and the Political Economy of the World. Leiden Journal of International Law, 2013.

Disponível em < http://journals.cambridge.org/abstract_S0922156512000635 > Acesso em 20 de jun. 2014.

LA PORTA, Rafael; LOPEZ-DE-SILANES, Florencio; SHLEIFER Andrei, The Economic Consequences of Legal Origins. Journal of Economic Literature, v. 46, 2008.

LANG, Andrew T.F. The Legal Construction of Economic Rationalities? Journal of Law and Society, v. 40, n. 1, p. 155-171.2013.

LIMA NETO, Oswaldo (Org.). Transporte no Brasil: história e reflexões. Distrito Federal: Empresa Brasileira de Planejamento de Transportes/ GEIPOT; Recife: Ed. Universitária da UFPE, 2001.

LOEWENSTEIN, Karl. Teoria de la Constitución. Barcelona: Editorial Ariel S.A., 1986,

MANKIW, N. Gregory. Introdução à Economia. São Paulo: Cengage Learnig, 2009. 
MENDES, Gilmar Ferreira \& BRANCO, Paulo Gustavo Gonet. Curso de Direito Constitucional. $8^{\mathrm{a}}$ ed. São Paulo: Saraiva, 2013.

MERCURO, N.; MEDEMA, S. G. Economics and the Law: From Posner to Postmodernism and Beyond. Princeton: Princeton University Press, 2006.

MIRAGAYA, Júlio. Perfil da distribuição dos postos de trabalho no Distrito Federal: concentração no Plano Piloto e déficits nas cidades-dormitório. Brasília: CODEPLAN/GDF, 2013.

MINISTÉRIO DAS CIDADES. Política Nacional de Mobilidade Urbana Sustentável. Princípios e Diretrizes aprovadas no Conselho das Cidades em setembro de 2004. Disponível em

http://www.capacidades.gov.br/biblioteca/detalhar/id/103/titulo/Cadernos+MCidades1+Politi

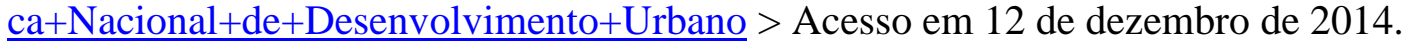

MIRANDA, Francisco Cavalcanti Pontes. Comentários à Constituição de 1946. $3^{\mathrm{a}}$ edição revista e aumentada. Editora Borsoi. Rio de Janeiro, 1960.

dos Tribunais, São Paulo, 1967.

Comentários à Constituição de 1967. Tomo IV. Editôra Revista Comentários à Constituição de 1967: com a Emenda n. 1 de 1969. Tomo IV. $3^{\text {a }}$ ed. Rio de Janeiro: Forense, 1987.

NEVES, Marcelo. Entre Hidra e Hércules: princípios e regras constitucionais. São Paulo: Editora WMF Martins Fontes, 2013.

POLETTI, Ronaldo. A Constituição de 1934. Brasília: As Constituições do Brasil, 1987.

POSNER, Richard A. Direito, Pragmatismo e Democracia. Rio de Janeiro: Forense, 2010.

2007.

Economic Analysis of Law. 8th ed. New York: Aspen Publishers, 
RIZZARDO, Arnaldo. Comentários ao Código de Trânsito Brasileiro. $7^{\mathrm{a}}$ ed. São Paulo: Editora Revista dos Tribunais, 2008.

SALAMA, Bruno Meyerhof. O que é Pesquisa em Direito e Economia? Fundação Getúlio Vargas. Estudo v. 5 n. 2. Março 2008.

SANTOS CARVALHO, Celso \& ROSSBACH, Claudia (org.) O Estatuto da Cidade: comentado $=$ The City Statute of Brazil: a commentary. São Paulo: Ministério das Cidades Aliança das Cidades, 2010.

SANTOS, Noronha. Meios de Transporte no Rio de Janeiro. $1^{\circ}$ volume. Rio de Janeiro: Typ. Do Jornal do Commercio. Rodrigues \& Co., 1934.

SCHOPPA, Renê Fernandes. Para onde caminham nossas ferrovias. Rio de Janeiro: Juruena \& Costa Velho Editores, 1982.

150 anos de trem no Brasil. Rio de Janeiro: Editoração

Vianopole Design e Comunicação Ltda., 2004.

SILVA, Virgílio Afonso da. Interpretação Constitucional e sincretismo metodológico in: idem (org.) Interpretação Constitucional. São Paulo: Malheiros, p. 115-143, 2005.

SMITH, Adam. A riqueza das nações. Investigação sobre a riqueza e as suas causas. Volume I. São Paulo: Editora Nova Cultural Ltda., 1996.

TERRA, Paulo Cruz. Conflitos cotidianos e motins: os usuários de bondes no Rio de Janeiro no final do século XIX e início do XX. In : História Social, $\mathrm{n}^{\circ} 22$ e 23, primeiro e segundo semestre de 2012. Disponível em http://www.ifch.unicamp.br/ojs/index.php/rhs/article/viewFile/1211/843 > Acesso em 13/02/2015.

TIMM, Luciano Benetti (org). Direito e Economia no Brasil. São Paulo: Editora Atlas, 2012.

VALE, André Rufino do. Estrutura das normas de direitos fundamentais: repensando a distinção entre regras, princípios e valores. São Paulo: Saraiva, 2009. 
VASCONCELLOS, Eduardo Alcântara de; CARVALHO, Carlos Henrique Ribeiro de; PEREIRA, Rafael Henrique Moraes. Transporte e mobilidade urbana. Brasília, DF: CEPAL, Escritório no Brasil/ IPEA, 2011. (Textos para Discussão CEPAL - IPEA, 34). Disponível em < http://www.cepal.org/brasil > Acesso em 17/09/2014.

WEBER, Max. Economia e Sociedade. Fundamentos da sociologia compreensiva. Volume 2. Brasília: Editora UNB, 2004.

WEBER, Max. Economy and Society. California: Stanford University Press, 2005.

WEID, Elisabeth von der. O Bonde como Elemento de Expansão Urbana no Rio de Janeiro. Siglo XIX, Cidade do México, n.16, p. 78-103, 1994. Disponível em < http://www.casaruibarbosa.gov.br > Acesso em 22/01/2015.

WRIGHT, Alan Armstrong. Urban Transit Systems. Guidelines for Examining Options. The WorldBank. Washington. D.C., USA, 1986.

\section{Referências Legislativas}

Constituição Política do Imperio do Brazil (de 25 de março de 1824). Disponível em < http://www.planalto.gov.br/ccivil 03/Constituicao/Constituicao91.htm > Acesso em 20 de out. de 2014.

Constituição da Republica dos Estados Unidos do Brasil (de 24 de fevereiro de 1891). Disponível em < http://www.planalto.gov.br/ccivil 03/Constituicao/Constituica091.htm> Acesso em 20 e out. de 2014.

Constituição a República dos Estados Unidos do Brasil (de 16 de julho de 1934). Disponível em < http://www.planalto.gov.br/ccivil 03/Constituicao/Constituicao34.htm > Acesso em 20 de out. de 2014.

Constituição dos Estados Unidos do Brasil (de 10 de novembro de 1937). Disponível em $<$ http://www.planalto.gov.br/ccivil 03/Constituicao/Constituica037.htm> Acesso em 20 de out. de 2014. 
Constituição dos Estados Unidos do Brasil (de 18 de setembro de 1946)._Disponível em < http://www.planalto.gov.br/ccivil 03/Constituicao/Constituicao46.htm > Acesso em 14 de jan. de 2015.

Constituição da República Federativa do Brasil de I967. Disponível em < http://www.planalto.gov.br/ccivil 03/Constituicao/Constituicao67.htm> Acesso em 14 de jan. de 2015.

Emenda Constitucional $n^{0}$ 1, de 17 de outubro de 1969. Disponível em < http://www.planalto.gov.br/ccivil 03/Constituicao/Constituica067.htm > Acesso em 15 de jan. de 2015.

Constituição da República Federativa do Brasil de 1988. Disponível em < http://www.planalto.gov.br/ccivil 03/constituicao/ConstituicaoCompilado.htm > Acesso em 15 de jan. de 2015.

Lei de 29 de agosto de 1828. (Estabelece regras para a construcção das obras publicas, que tiverem por objecto a navegação de rios, abertura de canaes, edificação de estradas, pontes, calçadas ou $\quad$ aqueductos.). Disponível em http://www2.camara.leg.br/legin/fed/lei sn/1824-1899/lei-38195-29-agosto-1828566164-norma-pl.html > Acesso em 21 de fev. de 2015.

Decreto $\mathrm{n}^{\mathbf{2}}$ 24, de 17 de Setembro 1835. (Autorisa o Governo a conceder privilegio exclusivo por tempo de 10 annos á Companhia denominada do -Rio Doce- ou a outra Companhia na falta desta, para navegar por meio de barcos de vapor, ou outros superiores, [...]) Disponível em < http://www2.camara.leg.br/legin/fed/decret/1824-1899/decreto24-17-setembro-1835-562387-publicacaooriginal-86394-pl.html > Acesso em 21 de fev. de 2015.

Decreto no 101, de 31 de Outubro de 1835. (Autorisa o Governo a conceder a uma ou mais Companhias, que fizerem uma estrada de ferro da Capital do Imperio para as de Minas Geraes, Rio Grande do Sul, e Bahia, o privilegio exclusivo por espaço de 40 annos [...]) Disponível em < http://www2.camara.leg.br/legin/fed/decret/1824-1899/decreto-101-31outubro-1835-562803-publicacaooriginal-86906-pl.html> Acesso em 22 de fev. de 2014.

Decreto $\mathrm{n}^{\circ}$ 641, de 26 de Junho de 1852. (Autorisa o Governo para conceder a huma ou mais companhias a construcção total ou parcial de hum cminho de ferro que, partindo do Municipio da Côrte, vá terminar nos pontos das Provincias de Minas Geraes e S. Paulo,[...]) Disponível em < http://www2.camara.leg.br/legin/fed/decret/1824-1899/decreto-641-26-junho1852-558790-norma-pl.html > Acesso em 22 de out. de 2014.

Decreto $\mathbf{n}^{0}$ 2.450, de 24 de Setembro de 1873. (Concede subvenção kilometrica ou garantia de juros ás Companhias que construirem estradas de ferro, na conformidade da Lei $n^{\circ} 611$ de 
26 de Junho de 1852). Disponível em < http://www2.camara.leg.br/legin/fed/decret/18241899/decreto-2450-24-setembro-1873-551003-publicacaooriginal-67086-pl.html > Acesso em 22 de out. 2014.

Decreto $n^{0}$ 6.995, de 10 de agosto de 1878. (Estabelece bases geraes para a concessão das estradas de ferro com fiança ou garantia de juros do Estado.) Disponível em < http://www2.camara.leg.br/legin/fed/decret/1824-1899/decreto-6995-10-agosto-1878547889-publicacaooriginal-62781-pe.html > Acesso em 25 de out. de 2014.

Decreto $n^{0}$ 159, de 15 de Janeiro de 1890. (Providencia sobre o modo de organização de um plano de viação federal.) Disponível em http://www2.camara.leg.br/legin/fed/decret/1824-1899/decreto-159-15-janeiro-1890523603-publicacaooriginal-1-pe.html > Acesso em 25 de out. de 2014.

Lei $\mathbf{n}^{\circ}$ 741, de 26 de dezembro de 1900. (Orça a receita geral da Republica dos Estados Unidos do Brasil para o exercicio de 1901, e dá outras providencias) Disponível em < http://www2.camara.leg.br/legin/fed/lei/1900-1909/lei-741-26-dezembro-1900-586193publicacaooriginal-109645-pl.html > Acesso em 23 de fev. de 2015.

Decreto $n^{0}$ 2.681, DE 7 de dezembro de 1912. (Regula a responsabilidade civil das estradas de ferro) Disponível em < http://www2.camara.leg.br/legin/fed/decret/19101919/decreto-2681-7-dezembro-1912-578354-publicacaooriginal-101207-pl.html > Acesso em 02 de mar. de 2015.

Decreto no 18.323, de 24 de Julho de 1928. (Approva o regulamento para a circulação internacional de automoveis, no territorio brasileiro e para a signalização, segurança do transito e policia das estradas de rodagem) Disponível em < http://www2.camara.leg.br/legin/fed/decret/1920-1929/decreto-18323-24-julho-1928516789-norma-pe.html > Acesso em 03 de mar. de 2015.

Decreto $\mathbf{n}^{0}$ 24.508, de 29 de Junho de 1934 (Define os serviços prestados pelas administrações dos portos organizados, uniformiza as taxas portuarias, quanto á sua espécie, incidencia e denominação, e dá outras providencias). Disponível em < http://www2.camara.leg.br/legin/fed/decret/1930-1939/decreto-24508-29-junho-1934499830-norma-pe.html > Acesso em 23 de mar. 2015.

Lei no 467, de 31 de Julho de 1937 (Transforma em Departamento Autônomo a atual Comissão de Estradas de Rodagem Federais, fixa os vencimentos do respectivo pessoal e dá outras providencias). Disponível em < http://www2.camara.leg.br/legin/fed/lei/19301939/lei-467-31-julho-1937-555595-publicacaooriginal-74903-pl.html > Acesso em 23 de mar. 2015. 
Decreto-Lei $\mathbf{n}^{0}$ 2.994, de 28 de Janeiro de 1941 (Código Nacional de Trânsito). Disponível em < http://www2.camara.leg.br/legin/fed/declei/1940-1949/decreto-lei-2994-28janeiro-1941-412976-publicacaooriginal-1-pe.html > Acesso em 23 de mar. 2015.

Decreto-Lei $\mathbf{n}^{\circ}$ 8.463, de 27 de dezembro de 1945 (Reorganiza o Departamento Nacional de Estradas de Rodagem, cria o Fundo Rodoviário Nacional e dá outras providências.) Disponível em < http://www.planalto.gov.br/ccivil 03/decreto-lei/1937-1946/Del8463.htm > Acesso em 25 de mar. 2015.

Lei $\mathbf{n}^{\circ}$ 1.102, de 18 de maio de 1950 (Aprova o Plano Salte e dispõe sobre sua execução). Disponível em < http://www2.camara.leg.br/legin/fed/lei/1950-1959/lei-1102-18-maio1950-363354-normaatualizada-pl.html > Acesso em 25 de mar. 2015.

Lei $\mathbf{n}^{0}$ 5.108, de 21 de setembro de 1966. (Institui o Código Nacional de Trânsito). Disponível em < http://www.planalto.gov.br/ccivil 03/leis/1950-1969/L5108.htm > Acesso em 26 de mar. de 2015.

Decreto-Lei $\mathbf{n}^{0}$ 122, de 31 de Janeiro de 1967 (Reorganiza o Departamento Nacional de Estradas de Rodagem e dé outras providências). Disponível em < http://www2.camara.leg.br/legin/fed/declei/1960-1969/decreto-lei-122-31-janeiro-1967375809-publicacaooriginal-1-pe.html > Acesso em 26 de mar. e 2015.

Ato Institucional $\mathrm{n}^{\mathbf{0}} \mathbf{5}$, de 13 de dezembro de 1968. Disponível em < http://www.planalto.gov.br/ccivil 03/AIT/ait-05-68.htm> Acesso em 25 de mar. de 2015.

Lei $n^{0}$ 6.256, de 22 de outubro de 1975. (Cria o Fundo Nacional de Apoio ao Desenvolvimento Urbano e dá outras providências). Disponível em < http://www.planalto.gov.br/ccivil_03/Leis/L6256.htm > Acesso em 27 de mar. 2015.

Lei $\mathrm{n}^{0}$ 6.261, de 14 de novembro de 1975. (Dispõe sobre o Sistema Nacional dos Transportes Urbanos, autoriza a criação da Empresa Brasileira dos Transportes Urbanos e dá outras providências) Disponível em < http://www.planalto.gov.br/ccivil_03/leis/19701979/L6261.htm > Acesso em 05 de abr. de 2015.

Lei $\mathrm{n}^{\circ}$ 8.987, de 13 de fevereiro de 1995. (Dispõe sobre o regime de concessão e permissão da prestação de serviços públicos previsto no art. 175 da Constituição Federal, e dá outras providências). Disponível em < http://www.planalto.gov.br/ccivil_03/Leis/L8987cons.htm $>$ Acesso em 13 de dez. de 2014. 
Lei no 9.503, de 23 de setembro de 1997. (Institui o Código de Trânsito Brasileiro.) Disponível em < http://www.planalto.gov.br/ccivil_03/LEIS/L9503.htm > Acesso em 14 de dez. de 2014.

Lei $\mathbf{n}^{0}$ 9.868, de 10 de novembro de 1999. (Dispõe sobre o processo e julgamento da ação direta de inconstitucionalidade e da ação declaratória de constitucionalidade perante o Supremo Tribunal Federal.) $\quad$ Disponível http://www.planalto.gov.br/ccivil_03/leis/L9868.htm > Acesso em 06 de abr. de 2015.

Lei $\mathrm{n}^{0}$ 10.098, de 19 de dezembro de 2000. (Estabelece normas gerais e critérios básicos para a promoção da acessibilidade das pessoas portadoras de deficiência ou com mobilidade reduzida, e dá outras providências.) Disponível em < http://www.planalto.gov.br/ccivil_03/LEIS/L10098.htm > Acesso em 06 de abr. de 2015.

Lei $\mathbf{n}^{\mathbf{0}}$ 10.233, de 5 de junho de 2001. (Dispõe sobre a reestruturação dos transportes aquaviário e terrestre, cria o Conselho Nacional de Integração de Políticas de Transporte, a Agência Nacional de Transportes Terrestres, a Agência Nacional de Transportes Aquaviários [...] Disponível em < http://www.planalto.gov.br/ccivil 03/leis/LEIS 2001/L10233.htm > Acesso em 08 de abr. 2015.

Lei $\mathbf{n}^{\mathbf{0}}$ 10.257, de 10 de julho de 2001. (Regulamenta os arts. 182 e 183 da Constituição Federal, estabelece diretrizes gerais da política urbana e dá outras providências.)

Disponível em < http://www.planalto.gov.br/ccivil 03/leis/LEIS 2001/L10257.htm > Acesso em 15 de nov. de 2014.

Medida Provisória $n^{0}$ 2.220, de 4 de setembro de 2001. (Dispõe sobre a concessão de uso especial de que trata o $\S 1^{\underline{0}}$ do art. 183 da Constituição, cria o Conselho Nacional de Desenvolvimento Urbano - CNDU e dá outras providências.)

Disponível em < http://www.planalto.gov.br/ccivil 03/mpv/2220.htm > Acesso em 16 de mai. 2015.

Lei $n^{0}$ 10.336, de 19 de dezembro de 2001. (Institui Contribuição de Intervenção no Domínio Econômico incidente sobre a importação e a comercialização de petróleo e seus derivados, gás natural e seus derivados, e álcool etílico combustível (Cide), e dá outras providências) Disponível em < http://www.planalto.gov.br/ccivil_03/leis/LEIS_2001/L10336.htm $>$ Acesso em 15 e nov. de 2014.

Lei $n^{0}$ 10.683, de 28 de maio de 2003. (Dispõe sobre a organização da Presidência da República e dos Ministérios, e dá outras providências) Disponível em < http://www2.camara.leg.br/legin/fed/lei/2003/lei-10683-28-maio-2003-496772normaatualizada-pl.html > Acesso em 15 de nov. de 2014. 
Lei $\mathbf{n}^{0}$ 10.741, de $1^{\circ}$ de outubro de 2003. (Dispõe sobre o Estatuto do Idoso e dá outras providências) Disponível em < http://www.planalto.gov.br/ccivil_03/leis/2003/L10.741.htm > Acesso em 15 de nov. de 2014.

Lei no 11.977, de 7 de julho de 2009. (Dispõe sobre o Programa Minha Casa, Minha Vida PMCMV e a regularização fundiária de assentamentos localizados em áreas urbanas; altera o Decreto-Lei $\mathrm{n}^{\mathrm{o}} 3.365$, de 21 de junho de 1941, as Leis $\mathrm{n}^{\mathrm{os}}$ 4.380, de 21 de agosto de 1964, 6.015, de 31 de dezembro de 1973, 8.036, de 11 de maio de 1990, e 10.257, de 10 de julho de 2001, e a Medida Provisória n⿳ ${ }^{\circ}$ 2.197-43, de 24 de agosto de 2001; e dá outras providências.) Disponível em < http://www.planalto.gov.br/ccivil 03/ ato2007-2010/2009/lei/l11977.htm > Acesso em 13 de dez. de 2014.

Lei $\mathbf{n}^{\mathbf{0}}$ 12.587, de 3 de janeiro de 2012. (Institui as diretrizes da Política Nacional de Mobilidade Urbana; revoga dispositivos dos Decretos-Leis nos 3.326 , de 3 de junho de 1941, e [...] Disponível em < http://www.planalto.gov.br/ccivil 03/ ato2011-2014/2012/lei//12587.htm $>$ Acesso em 15 de dez. de 2014.

Lei Distrital no 3.153, de 6 de 6 de maio de 2003. (Cria as Regiões Administrativas que especifica e dá outras providências.) Disponível em < http://legislacao.cl.df.gov.br/Legislacao/consultaNormaJuridicaNJURParaTextoL ei-85637!buscarNormaJuridicaNJURParaTextoLei.action > Acesso em 16 de mai. de 2015.

Lei Distrital $\mathbf{n}^{\mathbf{0}}$ 3.639, de 28 de julho de 2005. (Dispõe sobre a implantação de ciclovias nas rodovias do Distrito Federal.) Disponível em < http://www.buriti.df.gov.br/ftp/diariooficial/2005/07 Julho/DODF\%20143\%2029-072005/Seção01-\%20143.pdf > Acesso em 17 de mai. de 2015.

Lei Distrital $n^{0}$ 3.885, de 07 de julho de 2006. (Assegura, na forma que especifica, política de mobilidade urbana cicloviária de incentivo ao uso da bicicleta no Distrito Federal, e dá outras providências.) Disponível em http://www.buriti.df.gov.br/ftp/diariooficial/2006/07 Julho/DODF\%20131\%2011-072006/Seção01-\%20131.pdf > Acesso em 30 de mai.de mai. de 2015.

Lei Distrital $n^{0}$ 5022, de 04 de fevereiro de 2013. (Dispõe sobre o Estudo Prévio de Impacto de Vizinhança - EIV e dá outras providências). Publicado no Diário Oficial em 5 de fevereiro de 2013. Disponível em < http://www.buriti.df.gov.br/ftp/diariooficial/2013/02_Fevereiro/DODF\%20№\%20028\%20 05-02-2013/Seção01-\%20028.pdf> Acesso em 16 de dez. de 2014.

Decreto $n^{0}$ 5.031, de 2 de abril de 2004. (Dispõe sobre a composição, estruturação, competências e funcionamento do Conselho das Cidades, e dá outras providências.) 
Disponível em < http://www.planalto.gov.br/ccivil 03/ ato2004-2006/2004/decreto/d5031.htm > Acesso em 02 de jun. de 2015.

Decreto $n^{0}$ 5.790, de 25 de maio de 2006. (Dispõe sobre a composição, estruturação, competências e funcionamento do Conselho das Cidades - ConCidades, e dá outras providências.) Disponível em < http://www.planalto.gov.br/ccivil 03/ ato20042006/2006/Decreto/D5790.htm\#art22 > Acesso em 03 e jun. de 2015.

Decreto $\mathbf{n}^{\mathbf{0}}$ 7.764, de 22 de junho de 2012. (Altera o Decreto $\mathrm{n}^{\circ} 5.060$, de 30 de abril de 2004, que reduz as alíquotas da Contribuição de Intervenção no Domínio Econômico incidente sobre a importação e a comercialização de petróleo e seus derivados, gás natural e seus derivados, e álcool etílico combustível - CIDE.) revogado Disponível em < http://www.planalto.gov.br/ccivil 03/ Ato2011-2014/2012/Decreto/D7764.htm > Acesso em 03 de jun. de 2015.

Decreto do Governo Distrital $n^{0}$ 35.706, de 05 de agosto de 2014 (Regulamenta aspectos relacionados ao estudo de impacto de vizinhança, e dá outras providências), publicado no Diário Oficial do Distrito Federal em 06 de agosto de 2014.

http://www.buriti.df.gov.br/ftp/diariooficial/2014/08_Agosto/DODF\%20№\%20159 \%2006-08-2014/Seção01-\%20159.pdf > Acesso em 15 de dez. de 2014.

Resolução CONTRAN no 14 de fevereiro de 1998. (Estabelece os equipamentos obrigatórios para a frota de veículos em circulação e dá outras providências) Disponível em < http://www.denatran.gov.br/resolucoes.htm > Acesso em 25 de set. de 2015.

Resolução CONTRAN no 87 de maio de 1999. (Estabelece os equipamentos obrigatórios para a frota de veículos em circulação e dá outras providências) Disponível em < http://www.denatran.gov.br/resolucoes.htm > Acesso em 25 de set. e 2015.

Portaria no 23, de 6 de junho de 1994. Departamento Nacional de Combustíveis. RESOLVE: Proibir o consumo de óleo diesel em veículos automotores de passageiros, de carga e de uso misto com capacidade inferior a $1.000 \mathrm{~kg}$, altera o texto da Portaria DNC $\mathrm{N}^{\circ}$ 16 de 29/06/93. Disponível em < http://www.camara.gov.br/sileg/integras/409721.pdf > Acesso em 20 de junho de 2015.

Acórdãos e Votos disponíveis nos sítios eletrônicos do STF, STJ e TCU

ADI No 3.768-4. Disponível em $<$ http://redir.stf.jus.br/paginadorpub/paginador.jsp?docTP=AC\&docID=491812 >Acesso em 25 de junho de 2015. 
ADI No 2733-6. Disponível em

Disponivel em<

http://redir.stf.jus.br/paginadorpub/paginador.jsp?docTP=AC\&docID=266908 $>$ Acesso em 15 de jun. de 2015.

ADI No 2.999-1. Disponível em

$<$ http://redir.stf.jus.br/paginadorpub/paginador.jsp?docTP=AC\&docID=266908) $>$ Acesso em 15 de mar. de 2015.

HC n 300. Disponível em

<http://www.stf.jus.br/portal/cms/verTexto.asp?servico=sobreStfConhecaStfJulgamentoHisto

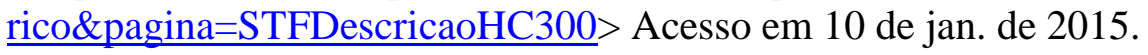

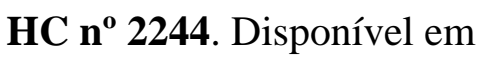

<http://www.stf.jus.br/portal/cms/verTexto.asp?servico=sobreStfConhecaStfJulgamentoHisto rico\&pagina=STFdescricaoHC2244> Acesso em 10 de jan. de 2015.

RE $\mathbf{n}^{\circ}$ 22.817. Disponível em

$<$ http://redir.stf.jus.br/paginadorpub/paginador.jsp?docTP=AC\&docID=609033 $>$ Acesso em 10 de jan. de 2015.

STA AG. 89 REG. Disponível em

$<$ http://redir.stf.jus.br/paginadorpub/paginador.jsp?docTP=AC\&docID=509461 > Acesso em 15 de jun. de 2015.

STJ - SLS n 1490/2013. Disponível em <

$<$ https://ww2.stj.jus.br/processo/revista/documento/mediado/?componente=MON\&sequencial $=20284911 \&$ num_registro $=201103038228 \&$ data $=20120214 \&$ formato $=$ PDF $>$ Acesso em 10 de jan. de 1015.

TCU - ACÓRDÃO No 1373/2011. Disponível em <

$<$ http://portal2.tcu.gov.br/portal/page/portal/TCU/imprensa/noticias/noticias_arquivos/TC\%2 0018\%20005_2010-1.pdf > Acesso em 15 dez de 2014.

\section{Sítios eletrônicos consultados:}

Disponível em <http://acervo.oglobo.globo.com/em-destaque/junho-de-2013-protestoscontra-aumento-da-passagens-se-espalham-pelo-pais-11101311> Acesso em 04 de fev. de 2015. 
Disponível

em

<http://www.em.com.br/app/noticia/gerais/2014/12/28/interna gerais,603081/coletivo-entrana-justica-contra-aumento-de-passagens-de-onibus-em-bh.shtml $>$ Acesso em $08 \mathrm{de} \mathrm{fev.} \mathrm{de}$ 2015.

Disponível em < http://www.antf.org.br/index.php/informacoes-do-setor/cronologia-historicaferroviaria $>$ Acesso em 20 out. 2014.

Disponível em < http://acervo.oglobo.globo.com/em-destaque/em-1925-brasil-viveassombroso-aumento-do-numero-de-automoveis-12367744 > Acesso em 31 de out. de 2014.

Disponível em < http://www2.uol.com.br/historiaviva/reportagens/a_morte_do_bonde.html $>$ Acesso em 08 de jan. 2015.

Disponível em 〈http://odia.ig.com.br/noticia/rio-de-janeiro/2014-10-26/circulacao-do-bondede-santa-teresa-surpreende-turistas-e-cariocas-na-lapa.html > Acesso em 27 de out. de 2014.

Disponível em < http://www.cnt.org.br/Paginas/Agencia_Noticia.aspx?n=7852> Acesso em 12 de jan. de 2015.

Disponível em <http://seriesestatisticas.ibge.gov.br/series.aspx?vcodigo=POP122 > Acesso em 12 de dez. de 2014.

Disponível em < http://www.dnit.gov.br/acesso-a-informacao/insitucional $>$ Acesso em 12 de dez de 2014.

Disponível em < http://www.cidades.gov.br/index.php/planejamento-urbano/350-campanhaplano-diretor.html > Acesso em 13 de dez. de 2014.

Disponível em < http://www.cidades.gov.br/index.php/progsemob/211-progmoburb.html > Acesso em 15 de jan. de 2015.

Disponível http://www.transportes.unb.br/downloads/eventos/politica_nacional_de_mobilidade_urbana.p $\underline{\text { df }}>$ Acesso em 13 de jan. de 2015

Disponível em <http://www.codeplan.df.gov.br/images/CODEPLAN/PDF/pesquisa_socioeconomica/pdad/2 013/Aguas_Claras2013-2014.pdf > Acesso em 13 de dez. de 2014.

Disponível

em 
Disponível em < http://www.aguasclaras.df.gov.br/a-regiao/dados-gerais.html $>$ Acesso em 19 jan. 2015.

Disponível em < http://www.novacap.df.gov.br/noticias/item/2358-df-\%C3\%A9refer\%C3\%AAncia-nacional-e-internacional-em-ciclovias.htm) >Acesso em 04 de set. de 2015.

Disponível em < www.codeplan.df.gov.br/.../274-caracterizacao-do-territorio-descritivo.h... > Acesso em 04 de set. de 2015.

Disponível em $\quad<\quad$ http://www.cl.df.gov.br/ultimas-noticias//asset_publisher/IT0h/content/falta-planejamento-integrado-para-mobilidade-sustentavelalertam-especialistas?redirect=http\%3A\%2F\%2Fwww.cl.df.gov.br\%2Finicio $>$ Acesso em 10 dez. 2014.

Disponível em < http://g1.glob.com/bom-dia-brasil/noticia/2013/05/ciclovias-do-df-sofremcom-falta-de continuidade-e-abuso-de motorias.html > Edição do dia 30/052013 12h:28 Atualizado em 30/05/2013 15h28. Acesso em 10 dez. 2014

Disponível em <http://exame.abril.com.br/brasil/noticias/onibus-de-sp-e-o-que-mais-pesa-nobolso-entre-12-metropoles >Acesso em 20 fev. 2015.

Disponível em < http://www.dftrans.df.gov.br/informacoes/tarifas.html $>$ Acesso em 10 jan. 2015

Disponível

em

http://www.correiobraziliense.com.br/app/noticia/cidades/2012/09/28/interna_cidadesdf,3250 44/vlt-deixa-de-ser-assunto-da-copa-e-nao-ficara-pronto-ate-o-evento.shtml > Acesso em 10 de jan. de 2015

Disponível em< http://www.df.gov.br/conteudo-agencia-brasilia/item/18749-brt-sulter\%C3\%A1-passagem-de-r\$-3-a-partir-de-28-de-mar\%C3\%A7o.html> Acesso em 30 de junho de 2015.

Disponível em < http://pordentrodeaguasclaras.blogspot.com.br/2012/05/transito-intenso-omaior-problema-de.html > Acesso em 01 de fev. de 2015.

Disponível

em

$<$

http://www.correiobraziliense.com.br/app/noticia/cidades/2015/03/28/interna cidadesdf,4 77365/moradores-de-aguas-claras-e-vicente-pires-reclamam-de-infraestrutura.shtml > Acesso em 28 de mar. de 2015.

Disponível em http://www.dftrans.df.gov.br/images/PDFs/composicao\%20das\%20tarifas.pdf Acesso em 20 de jan. 2015. 
Disponível em < http://www.novacap.df.gov.br/noticias/item/2358-df-\%C3\%A9refer\%C3\%AAncia-nacional-e-internacional-em-ciclovias.htm) $>$ Acesso em 04 de set. de 2015.

Disponível em < http://www.detran.df.gov.br/o-detran/estatisticas-dotransito/acidentes.html > Acesso em 20 de jan. de 2014. 